\title{
Topographical mapping of isoform-selectivity determinants for J-channel-binding inhibitors of sphingosine kinases 1 and 2
}

\author{
David R. Adams, ${ }^{\ddagger}$ Salha Tawati, ${ }^{\dagger}$ Giacomo Berretta, ${ }^{\dagger}$ Paula Lopez Rivas, ${ }^{\dagger}$ Jessica Baiget, ${ }^{\dagger}$ Zhong \\ Jiang,,${ }^{\ddagger}$ Aisha Alsfouk, ${ }^{\dagger}$ Simon P. Mackay ${ }^{\dagger}$ Nigel J. Pyne, ${ }^{\dagger}$ and Susan Pyne,,${ }^{*}$ \\ †Strathclyde Institute of Pharmacy and Biomedical Sciences, University of Strathclyde, Glasgow \\ G4 0RE, UK \\ \$School of Engineering \& Physical Sciences, Heriot-Watt University, Edinburgh EH14 4AS, UK
}

\begin{abstract}
Sphingosine kinase enzymes (SK1 and SK2) catalyse the conversion of sphingosine into sphingosine 1-phosphate and play a key role in lipid signaling and cellular responses. Mapping of isoform amino acid sequence differences for SK2 onto the recently available crystal structures of SK1 suggests that subtle structural differences exist in the foot of the lipid-binding 'J-channel' in SK2, the structure of which has yet to be defined by structural biology techniques. We have probed these isoform differences with a ligand series derived from the potent SK1-selective inhibitor, PF543. Here we show how it is possible, even with relatively conservative changes in compound structure, to systematically tune the activity profile of a ligand from $c a$. 100-fold SK1-selective inhibition, through equipotent SK1/SK2 inhibition, to reversed 100-fold SK2 selectivity, with retention of nanomolar potency.
\end{abstract}




\section{INTRODUCTION}

Sphingosine 1-phosphate (S1P) is a key signalling lipid derived from sphingosine (Sph) by the action of sphingosine kinases (SK1 and SK2). S1P is transported to the extracellular environment, where it functions as a ligand for a family of five $\mathrm{S} 1 \mathrm{P}$-specific $\mathrm{G}$ protein coupled receptors $\left(\mathrm{S}_{\mathrm{P}} \mathrm{P}_{1-5}\right)$, but it also acts on specific intracellular target proteins, such as histone deacetylases $1 / 2$ (HDAC1/2). ${ }^{1,2}$ Irreversible cleavage of S1P is catalysed by S1P lyase, producing $(E)-2-$ hexadecenal and phosphoethanolamine, ${ }^{3}$ but S1P is also reversibly dephosphorylated by S1P phosphatase to regenerate $\mathrm{Sph},{ }^{4-6}$ levels of which are additionally influenced by flux through the ceramide (Cer) synthesis pathway. ${ }^{7}$ The effects of S1P on cell function favour proliferation, migration, differentiation and survival and are generally opposed by Cer, which induces apoptosis, senescence and growth arrest. ${ }^{8,9}$ As a consequence the concept of the 'sphingolipid rheostat' was proposed, ${ }^{10,11}$ in which the inter-conversion of Cer via Sph to S1P controls cellular fate (recently reviewed $^{12,13}$ ). Altered S1P signalling has been associated with numerous pathophysiologies, including cancer, cardiovascular disease, neurodegenerative conditions, diabetes and inflammatory disease. ${ }^{14}$ The possibility of manipulating the sphingolipid rheostat for therapeutic purposes has therefore provided a rationale for exploring the development of SK inhibitors and their potential to reduce S1P formation and signalling and to raise pro-apoptotic Cer levels.

The SK1 and SK2 enzymes are encoded by distinct genes and differ in their subcellular localisation, biochemical properties and functions; there are three N-terminal variants of SK1 and two N-terminal variants of SK2. ${ }^{15}, 16$ A number of classes of SK inhibitors have emerged in the last two decades, including the recent discovery of an ATP-competitive SK inhibitor chemotype that decreases cellular S1P levels, elevates Sph/Cer, induces apoptosis, and that inhibits cell proliferation and colony formation. ${ }^{17}$ Most work to date, however, has focused on the development 
of Sph-competitive inhibitors. This includes the development of inhibitors selective for SK1 that exhibit nanomolar potency, such as PF-543 (1), ${ }^{18}$ Genzyme-51 (2) ${ }^{19}$ and Amgen-23 (3), ${ }^{20}$ Chart 1. PF-543 reduces sickling of red blood cells ${ }^{21}$ in vitro and in vivo and attenuates post-infarction cardiac remodeling. ${ }^{22}$ We have also demonstrated ${ }^{23}$ that $\mathrm{PF}-543$ protects against cardiomyocyte apoptosis and reduces cardiac maladaptive hypertrophy in a mouse model of pulmonary hypertension. 


\section{Chart 1. Lipid substrate (Sph), product (S1P) and established inhibitors for SK1 and SK2.}

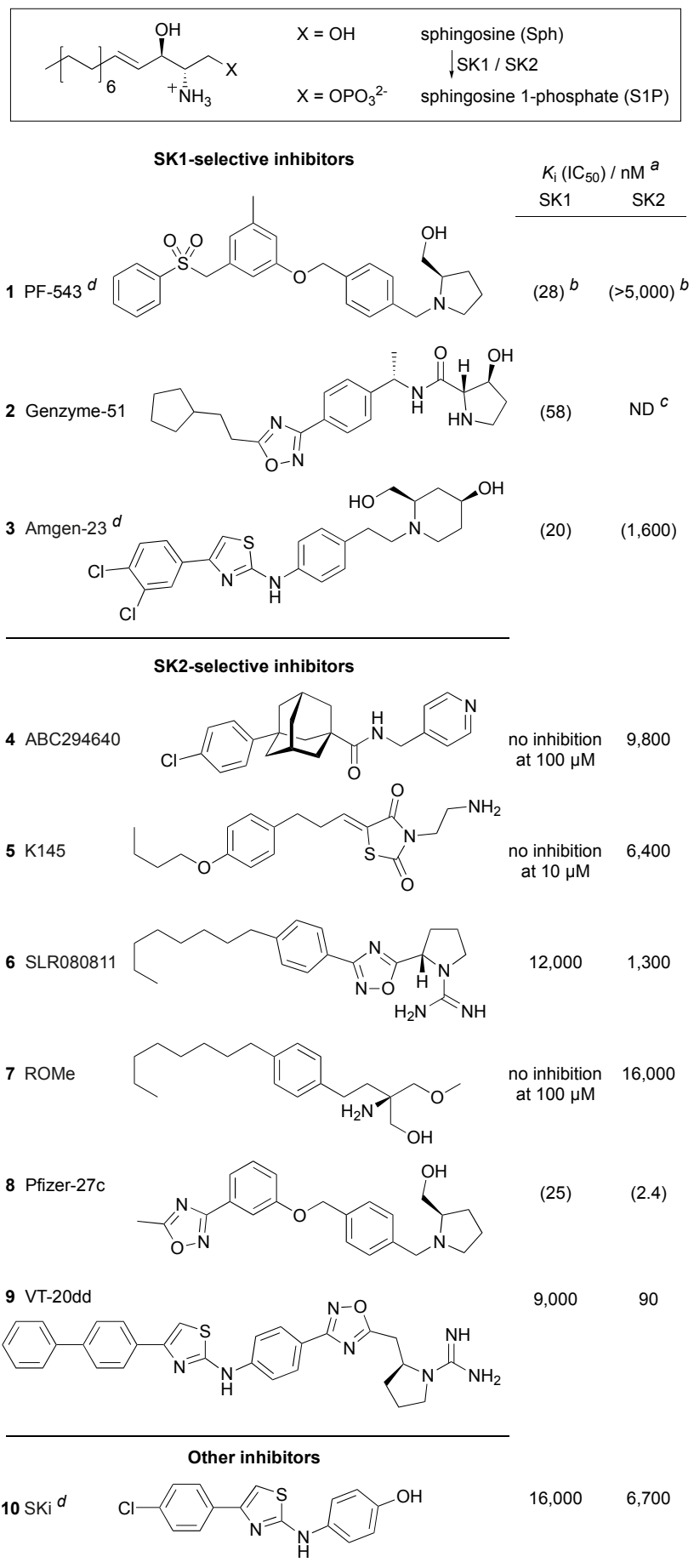

${ }^{a}$ For references see text. ${ }^{b}$ This study. ${ }^{c}$ No data. ${ }^{d}$ Co-crystal structure available with SK1. 
Early prototype Sph-competitive SK2-selective inhibitors include ABC294640 (4), ${ }^{24} \mathrm{~K} 145$ (5), ${ }^{25}$ SLR0808110 (6) ${ }^{26}$ and (R)-FTY720 methyl ether (ROMe; 7), ${ }^{27}$ Chart 1. Of these compounds, ABC294640, which induces cell death via apoptotic and autophagic pathways, ${ }^{24,28}$ has been tested in several disease models for cancer, ${ }^{24}$ rheumatoid arthritis ${ }^{29}$ and ulcerative colitis. ${ }^{30}$ The compound has proceeded to phase I/II clinical studies targeting multiple oncology and inflammatory indications. However, $\mathrm{ABC} 294640$ also indirectly targets dihydroceramide desaturase and induces the proteasomal degradation of SK1 in prostate cancer cells and in HEK293T cells. ${ }^{31-33} \mathrm{ROMe}$, an SK2-selective inhibitor $\left(K_{\mathrm{i}} 14 \mu \mathrm{M}\right)$ with no activity against SK1 at $100 \mu \mathrm{M}$, inhibits DNA synthesis in breast cancer cells and induces autophagic death of T-cell acute lymphoblastic leukemic cells. ${ }^{27,}{ }^{34}$ Very recently two reports have disclosed examples of more potent SK inhibitors, Pfizer-27c (8) ${ }^{35}$ and VT-20dd (9) ${ }^{36}$ with selectivity for SK2. Despite these developments and a growing interest in the (patho)physiological roles of SK2, a clear structural rationale for the development of high potency SK2-specific inhibitors has yet to emerge.

No SK2 crystal structures are available as yet to support structure-based design of SK2selective inhibitors, but amino acid sequence alignment suggests a high degree of homology to SK1, the structure of which has recently been solved by X-ray crystallography. ${ }^{37,20,38}$ SK1 exhibits a bidomain architecture comprising an ATP-binding N-terminal domain (NTD) and a C-terminal domain (CTD) that hosts the Sph binding site, Figure 1. The CTD folds as a two-layer $\beta$-sandwich with three extended inter-strand loops packing across one face to generate the Sph binding site as a J-shaped cavity, termed the 'J-channel'. One of the three 'lipid binding loops', LBL-1, consists of two reverse-paired helices ( $\alpha 7$ and $\alpha 8)$ that may gate substrate entry and product egress by a hinged motion. ${ }^{39}$ Residues in LBL-1 and in the second loop, LBL-2, define much of the contact surface for the polar head group and central region of the lipid. The third loop, LBL-3, folds with 
an additional helix ( $\alpha 9$ ), running antiparallel along $\alpha 8$, and provides enclosure for the lipid tail. To date, SK1 co-crystal structures have been acquired with three inhibitors bound in the J-channel, namely with SKi (10; also known as SKI-II), ${ }^{37}$ with Amgen-23 (3), ${ }^{20}$ and most recently with PF$543(1) .{ }^{38}$ We have used the latter structure as a starting point to explore differences in the foot of the J-channel of SK1 and SK2. Here we report our results from a ligand-based structure activity relationship (SAR) study that highlights key determinants for switching between SK1-selective and SK2-selective inhibition.

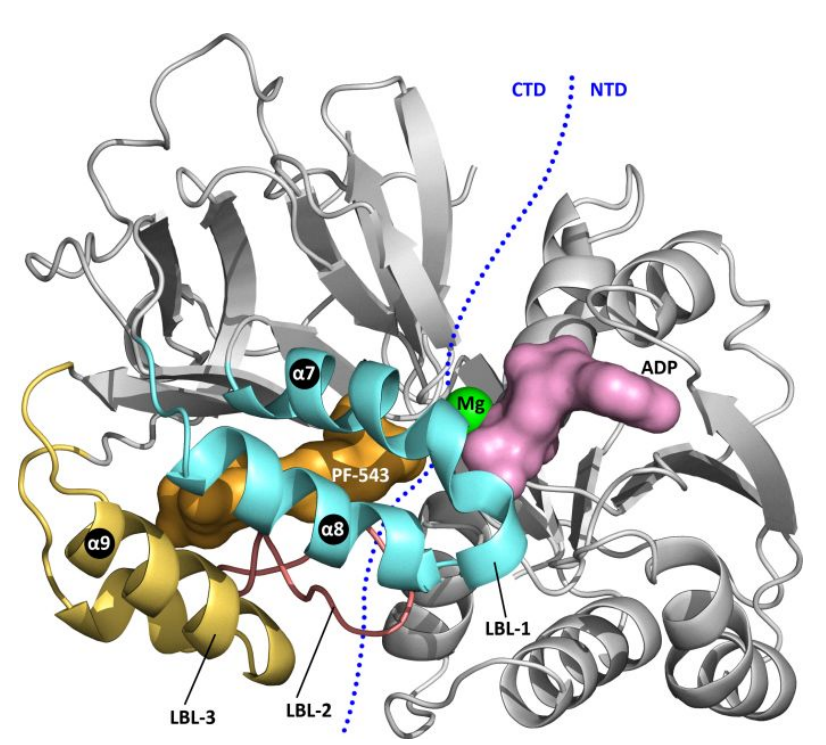

Figure 1. The structure of SK1 is shown with bound PF-543 (1; orange surface) (PDB: 4V24). ${ }^{38}$ PF-543 occupies the substrate Sph binding site, formed by the packing of three lipid binding loops (LBL-1 to LBL-3) against a $\beta$-sandwich core. The nucleotide binding site is shown by superimposition of Mg-ADP (green sphere/rose surface) from its separate co-crystal structure (3VZD) with SK1.37 


\section{RESULTS AND DISCUSSION}

Design rationale for ligand selectivity switching. Of the 20 or so residues that contribute to the J-channel in SK1, SK2 differs at only 3 points in the direct hydrophobic contact surface of the binding site - namely in Ile174, Met272 and Phe288 of SK1, corresponding respectively to Val304, Leu517 and Cys533 in SK2 (Figure 2, orange). Phe288 stoppers the toe of the SK1 Jchannel, and its substitution by Cys533 in SK2 may result in a longer J-channel and potentially also confer greater surface plasticity in that region of SK2 due to loosened packing against adjacent hydrophobic residues. Ile174 and Met272 contribute to the throat of the J-channel and, in the SK1/PF-543 co-crystal structure, are seen to form part of the flanking surface on either side of the inhibitor's $p$-xylylene subunit; their replacement by Val and Leu may make this region of the Jchannel slightly wider in SK2 than in SK1. Ile174 additionally contributes surface on one edge of the PF-543 terminal subunit, with contact distances of 3.6 and $3.4 \AA$ between its $\mathrm{C} \delta$ methyl carbon and the PF-543 phenyl ortho and meta carbons respectively. A leucine (Leu261; Figure 2, yellow), that is packed against Ile174 in SK1, also contributes to the contact surface around the edge of the PF-543 terminal phenyl and, although conserved in SK2 (as Leu506), may differ in its conformational profile due to the replacement of the adjacent Ile174 in SK1 by Val304 in SK2. Together, these considerations suggest that the J-channel toe might be expanded in SK2 on a contact surface mapping to the para-position of the terminal phenyl of SK1-bound PF-543 (Figure 2, green arrow). 




Figure 2. J-channel surface detail (mesh) from the PF-543/SK1 co-crystal (PDB: 4V24), ${ }^{38}$ highlighting key isoform residue differences that likely impact on the J-channel structure of SK2. SK1 residue numbering is shown; cognate SK2 residues, where different, are in parenthesis. (Residue color notation: see text.)

In principle, an expanded surface in SK2 at the J-channel toe might contribute to reduced affinity for PF-543 and hence, at least in part, to the established SK1-over-SK2 selectivity of this inhibitor (Chart 1). However, SK2 also differs from SK1 in several other residues that, whilst not contributing directly to the ligand contact surface, are likely to indirectly affect the J-channel structure. Thus, a set of residues in LBL-3 of SK1 (Val294, Met298, Met312, Tyr314, Tyr318; Figure 2, green) differs in SK2 (as Ile539, Ala543, Phe557, Leu559 and Gln563 respectively). Inspection of the SK1/PF-543 co-crystal structure suggests that these differences may impact on the conformation of a conserved leucine (Leu302 in SK1; Figure 2, magenta), which contributes to the contact surface for the sulfonyl group of PF-543. We hypothesized that the cognate residue (Leu547) in SK2 might be driven inwards to narrow the J-channel at that point. If so, surface encroachment in the J-channel heel of SK2 might then interdict comfortable accommodation of 
the sulfonyl oxygens of PF-543 and also contribute to the observed SK1-selectivity of this inhibitor.

Two further residue differences, Ala175 and Ala339 in SK1 (corresponding to Ser305 and Thr584 in SK2), might also potentially be relevant to isoform discrimination by ligands targeting the J-channel. These residues (Figure 2, cyan) lie proximal to the 2-(hydroxymethyl)pyrrolidine 'head group' of PF-543, and their variation in SK2 might affect a network of polar interactions that engages the PF-543 head group or/and slightly reposition LBL-1 with respect to the $\beta$ sandwich core, which could then impact on the surface of a notch in the J-channel that accommodates the PF-543 methyl group (Figure 2). However, it is known ${ }^{38}$ that the hydroxyl group of SK1-bound PF-543 precisely maps to the position of the Sph-3-OH and, given that Sph serves as a substrate for both SK1 and SK2, it is likely that the 'head group' hydrogen bonding features in SK2 should also support the binding of the PF-543 2-(hydroxymethyl)pyrrolidine subunit. Thus, in seeking to identify determinants for SK2-selective inhibition, we focused attention on a series of PF-543 analogues that retained the 2-(hydroxymethyl)pyrrolidine head group but embodied alterations to the tail targeted to the enclosed J-channel foot, predicted by our analysis to offer scope for isoform-discriminating interactions with ligands. Accordingly, we prepared a concise compound test set to evaluate whether SK2-inhibitory activity might be enhanced by alleviating steric demand in the sulfonyl linker and/or by deletion of the PF-543 methyl group. We also sought to test the hypothesis that optimisation of ligand fit to the J-channel toe in SK2 might confer selectivity over SK1.

Synthesis of probe compound set. In order to assess the contribution of the methyl group to the SK1 selectivity of PF-543, we prepared the normethyl analogue (18; Scheme 1) for evaluation. The compound was prepared from $m$-methoxybenzyl bromide (11) by reaction with 
sodium benzenesulfinate followed by boron tribromide mediated cleavage of the aryl methyl ether in $\mathbf{1 2}$ to afford phenol 14. The latter was then alkylated with 4-(bromomethyl)benzaldehyde and the resulting aldehyde (16) subjected to reductive amination with $(R)-(-)$-prolinol.

\section{Scheme 1. Synthesis of probe compounds 18 and 19. ${ }^{a}$}

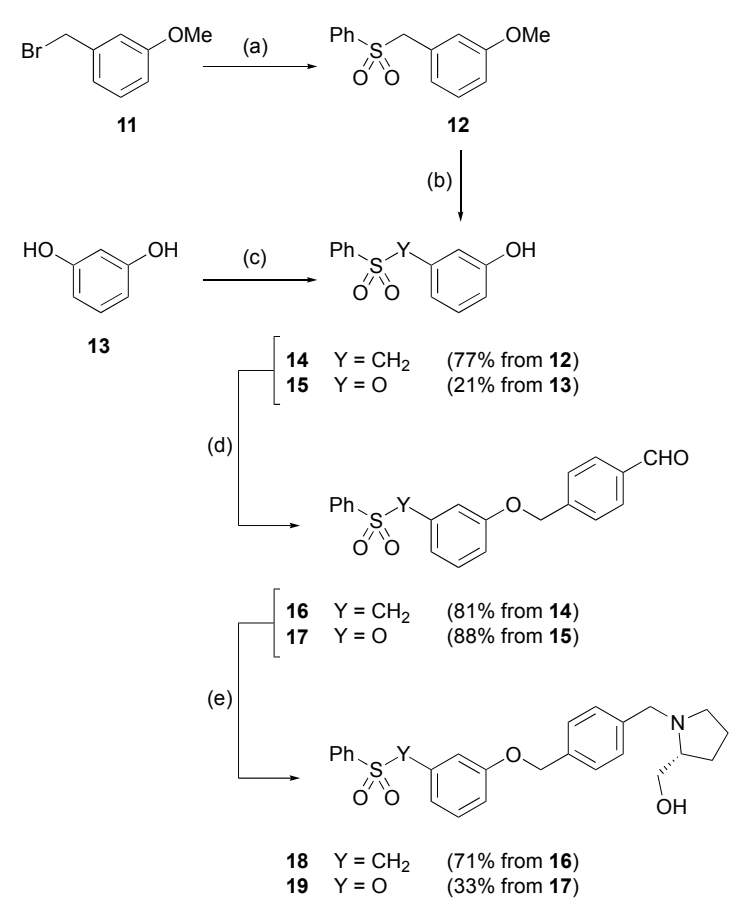

${ }^{a}$ Reagents and conditions: (a) $\mathrm{NaSO}_{2} \mathrm{Ph}$, Aliquat ${ }^{\circledR} 336,85^{\circ} \mathrm{C}$ (47\%); (b) $\mathrm{BBr}_{3}, \mathrm{CH}_{2} \mathrm{Cl}_{2},-78^{\circ} \mathrm{C}$ (77\%); (c) phenylsulfonyl chloride $\mathrm{K}_{2} \mathrm{CO}_{3} / \mathrm{MeCN}$ (21\%); (d) 4-(bromomethyl)benzaldehyde, $\mathrm{K}_{2} \mathrm{CO}_{3}, \mathrm{MeCN}, 60^{\circ} \mathrm{C}$; (e) (R)-2-(hydroxymethyl)pyrrolidine, $\mathrm{NaBH}(\mathrm{OAc})_{3}$, DCE.

A collection of compounds was then prepared in order to evaluate the contribution of the $-\mathrm{SO}_{2}-\mathrm{CH}_{2}-$ tail linker to inhibitory performance and selectivity. Analogues were designed to test the impact of replacing the PF-543 sulfonyl group by methylene, but we also included an isosteric sulfonate (19) to probe the impact of subtle changes in ligand bond angle preferences. Sulfonate 19 was prepared by initial sulfonylation of resorcinol (13) followed by alkylation of the resulting 
phenol (15) with 4-(bromomethyl)benzaldehyde and reductive amination with $(R)-(-)$-prolinol, Scheme 1.

The ethylene-linked analogue (23, Scheme 2$)$ was prepared to assess the impact of reducing steric demand in the locus occupied by the PF-543 sulfonyl group. For reasons of synthetic convenience, this and other sulfonyl deletion analogues were prepared for comparative evaluation against 18 without the methyl group in place on the central arene ring. Synthesis of 23 was undertaken from acetylene 20, prepared by ambient temperature Sonogashira coupling of 3iodophenol ${ }^{40}$ with phenylacetylene. The acetylene was hydrogenated to afford phenol $\mathbf{2 1}$, which was alkylated with 4-(bromomethyl)benzaldehyde to afford 22. Reductive amination of the latter with $(R)-(-)$-prolinol afforded 23.

\section{Scheme 2. Synthesis of probe compound $23 .^{a}$}

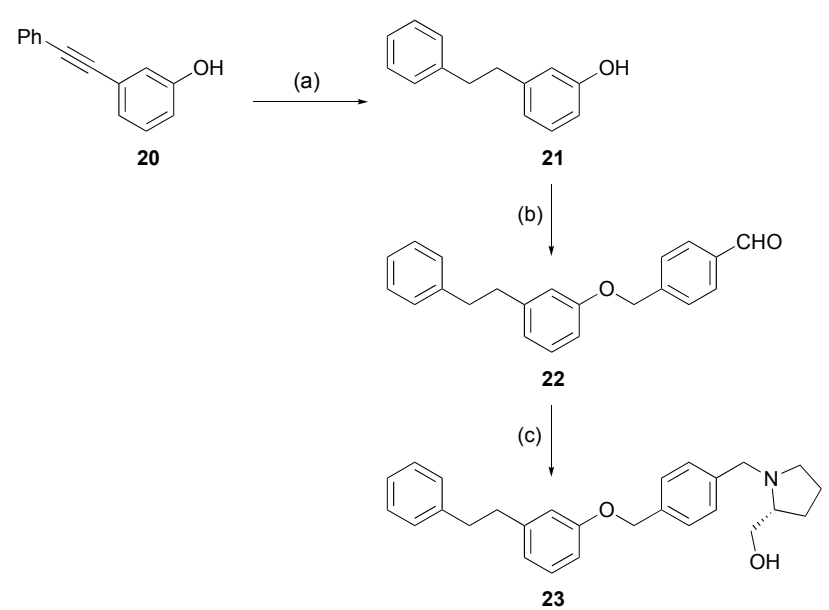

${ }^{a}$ Reagents and conditions: (a) $\mathrm{H}_{2}, \mathrm{Pd} / \mathrm{C}, \mathrm{EtOH}$ (95\%); (b) 4-(bromomethyl)benzaldehyde, $\mathrm{K}_{2} \mathrm{CO}_{3}$, $\mathrm{MeCN}, 20{ }^{\circ} \mathrm{C}, 16 \mathrm{~h}(87 \%)$; (c) (R)-2-(hydroxymethyl)pyrrolidine, $\mathrm{NaBH}(\mathrm{OAc})_{3}, \mathrm{DCE}(82 \%)$.

An ether-linked variant (49) of 23 was prepared according to Scheme 3. Thus, resorcinol (13) was alkylated with benzyl bromide and the resulting phenol (25) transformed into 49 by the 
two-step alkylation/reductive amination procedure applied in Schemes 1 and 2 for compounds $\mathbf{1 8}$, 19 and 23. A subset of six halogenated analogues (50-55, Scheme 3) was then expanded to facilitate systematic exploration of the space in the J-channel foot. Two further analogues were included in the ether-linked test set to explore the impact of steric demand in the critical toe region of the J-channel—namely, methyl ether $\mathbf{5 6}$ and nitrile 57, with bent and linear two-atom extensions from the para-position of the tail arene. The sulfide counterpart (58) of the ether-linked parent (49) was prepared in a similar manner starting from benzenethiol (24). The para-fluorophenyl and para-chlorophenyl analogues (59 and 60) of this latter compound were made by a similar strategy. Sulfides 58-60 were included to test the impact of incorporating a heteroatom in the linker with greater steric demand and differing bond angle preferences, which might impact on positioning of the ligand's terminal para-site in the critical J-channel toe region. 
Scheme 3. Synthesis of probe compounds 49-60. ${ }^{a}$
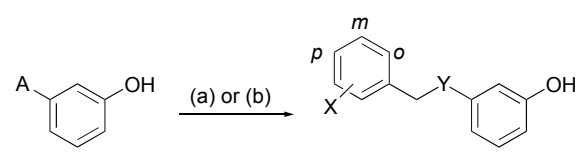

$13 \mathrm{~A}=\mathrm{OH}$
$24 \mathrm{~A}=\mathrm{SH}$
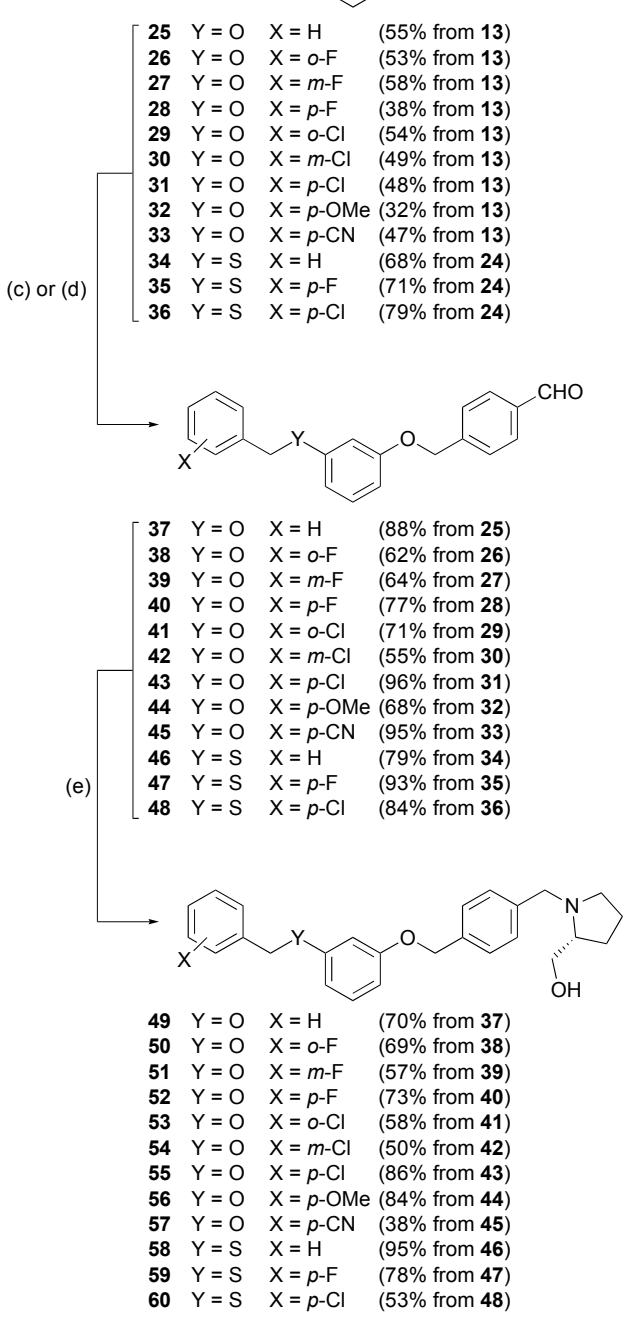

${ }^{a}$ Reagents and conditions: (a) 25-33: (substituted)benzyl bromide (or 4-chlorobenzyl chloride in the case of 31), $\mathrm{K}_{2} \mathrm{CO}_{3}$, acetone, $65^{\circ} \mathrm{C}, 5 \mathrm{~h}$; (b) 34-36: (substituted)benzyl bromide (or 4chlorobenzyl chloride in the case of 36), $\mathrm{K}_{2} \mathrm{CO}_{3}, \mathrm{MeCN}, 20{ }^{\circ} \mathrm{C}, 16 \mathrm{~h}$; (c) 37-45: $\mathrm{NaH}$, DMF, then 4-(bromomethyl)benzaldehyde, $16 \mathrm{~h}, 20{ }^{\circ} \mathrm{C}$; (d) 46-48: 4-(bromomethyl)benzaldehyde, $\mathrm{K}_{2} \mathrm{CO}_{3}$, $\mathrm{MeCN}, 20^{\circ} \mathrm{C}$, $16 \mathrm{~h}$; (e) (R)-2-(hydroxymethyl)pyrrolidine, $\mathrm{NaBH}(\mathrm{OAc})_{3}$, THF (for 49-57) or DCE (for 48-60). 
SK-inhibitory performance and selectivity of probe compound set. Compounds were evaluated for inhibition of purified SK1 and SK2 using a radiometric assay, as detailed in our earlier work. ${ }^{41}$ In brief, the procedure uses $\left[\gamma-{ }^{32} \mathrm{P}\right] \mathrm{ATP}$ and measures incorporation of the radiolabelled phosphate into the S1P product. SK1 and SK2 were assayed, respectively, at 3 and $10 \mu \mathrm{M}$ Sph substrate concentration. These concentrations correspond to the $\mathrm{K}_{\mathrm{m}}$ values of SK1 $1^{42-44}$ and $\mathrm{SK} 2{ }^{27}$ and, therefore, allow direct comparison of the sensitivity of the two enzymes at $50 \%$ saturation with Sph. Assays were performed with ATP at $250 \mu \mathrm{M}$ concentration, well above the $\mathrm{K}_{\mathrm{m}}$ value for the nucleotide, to ensure saturation with ATP. Activity data are summarised in Chart 2. 
Chart 2. SK1 and SK2 inhibitory activity for probe compound set derived from PF-543 (1). ${ }^{a}$

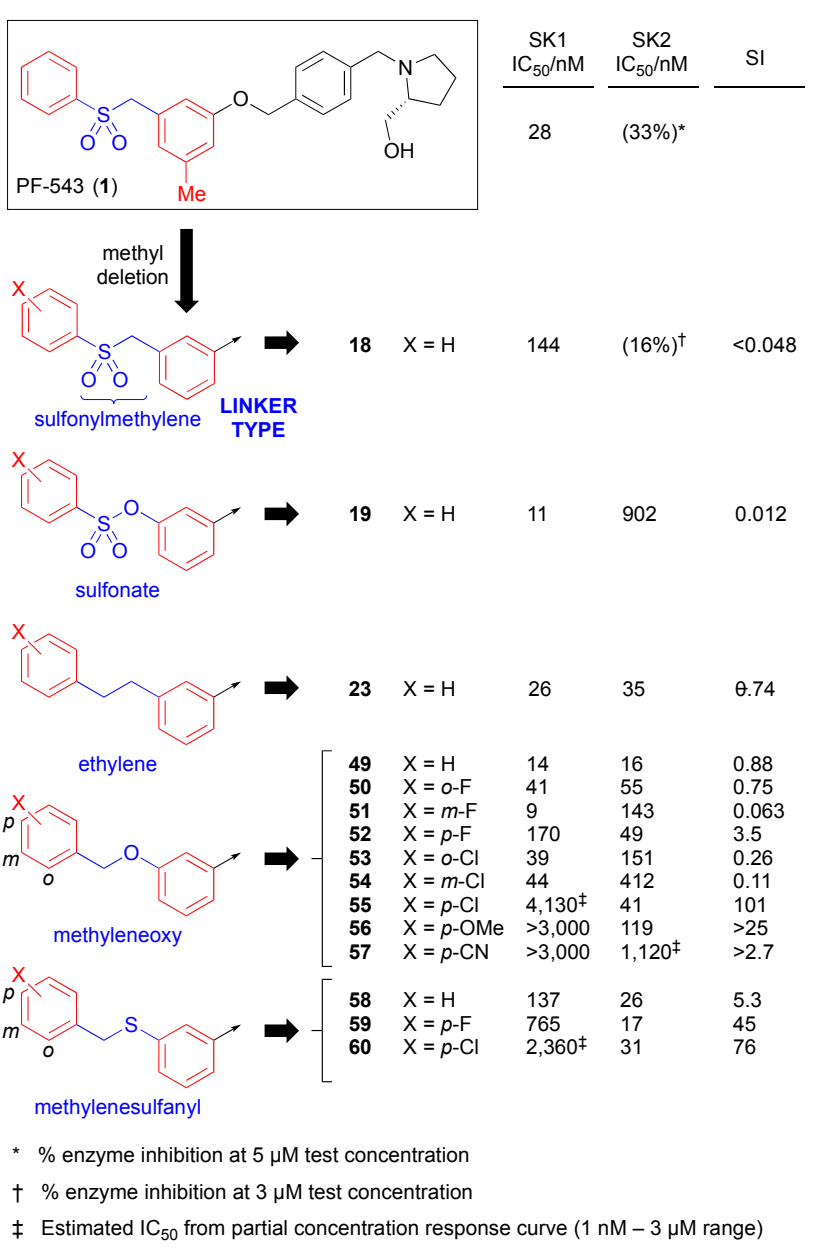

${ }^{a}$ SK1 activity was assayed using $3 \mu \mathrm{M}$ Sph and $250 \mu \mathrm{M}$ ATP. SK2 activity was assayed using 10 $\mu \mathrm{M}$ Sph and $250 \mu \mathrm{M}$ ATP. Data are reported as $\mathrm{IC}_{50}$ values (or \% enzyme inhibition) vs control determined in triplicate assays. NE: no inhibitory effect at maximal test concentration of $3 \mu \mathrm{M}$. SI denotes selectivity index as $\mathrm{IC}_{50}(\mathrm{SK} 1) / \mathrm{IC}_{50}(\mathrm{SK} 2)$.

We have previously obtained ${ }^{41}$ an $\mathrm{IC}_{50}$ of $28 \mathrm{nM}$ for inhibition of SK1 by PF-543 in our assay, considerably higher than the $K_{\mathrm{i}}$ value of $3.6 \mathrm{nM}$ reported by Schnute et al. ${ }^{18}$, with the caveat that the latter determination was performed under conditions where ATP was not saturating and 
therefore subject to two-substrate kinetics. As reported, however, PF-543 was highly selective for inhibition of SK1, giving only $33 \%$ inhibition of SK2 at $5 \mu \mathrm{M}$ and $72 \%$ at $50 \mu \mathrm{M}$.

Our analysis (vide supra) suggested that the most likely explanation for the SK1-over-SK2 selectivity of PF-543 is due to surface encroachment in the SK2 J-channel heel targeted by the inhibitor's sulfonyl group (Figure 2, red arrow). However, at the outset of our studies we could not eliminate the possibility that structural differences in the sub-pocket that accommodates the PF543 methyl group (Figure 2, 'notch') might also be a contributory factor. We therefore evaluated the normethyl analogue (18) of PF-543. This compound showed a modest (5-fold) loss in SK1inhibitory potency compared to PF-543, consistent with a slight reduction in favourable surface contact with that isoform. However, the gain in SK2 inhibition that might have been expected for relief of an unfavourable surface compression against the methyl, was not observed. Indeed, only slight inhibition of SK2 (16\%) was detectable at the maximal test concentration of $3 \mu \mathrm{M}$ in our current studies, suggesting that the PF-543 methyl group is not a strong determinant of selectivity. During the course of our studies Schnute et al. disclosed ${ }^{35}$ further details of their development of PF-543, including comparative activity data for normethyl analogue $\mathbf{1 8}$ using a different assay system. In this study the methyl group was also shown to contribute only marginally to the strong SK1-selectivity of PF-543; its deletion led to a change in selectivity by less than a factor of 2.

Interestingly the sulfonate analogue (19) was 13-fold more potent against SK1 than its counterpart (18) with the sulfonylmethylene linker. A corresponding increase in inhibitory potency was also seen against SK2, with a quantifiable $\mathrm{IC}_{50}$ of $902 \mathrm{nM}$ determined. Replacement of the sulfonyl group in $\mathbf{1 8}$ with a second methylene in $\mathbf{2 3}$ led to a modest 5.5-fold improvement in potency against SK1 but a pronounced enhancement in potency against SK2 so that the compound was almost equipotent against both isoforms ( $\mathrm{IC}_{50} 26$ and $35 \mathrm{nM}$ for $\mathrm{SK} 1$ and SK2 respectively). 
Taken together, these results suggest that the heel of the SK1 J-channel might be a tight fit for the sulfonylmethylene linker in PF-543 and 18 and supported our hypothesis that in SK2 the J-channel heel may be tighter still, encroaching sufficiently on the sulfonyl oxygens so as to be a key determinant for isoform discrimination. Thus, in SK2 higher compression is postulated along a trajectory (Axis-1 in Figure 3) between the head group and sulfonyl oxygens of the ligand, with the head group locked in place by a highly organised network of polar interactions involving features that normally serve to position the substrate for phosphorylation. These 'headlock' features include a structural water and an aspartic acid on helix- $\alpha 7$ (Asp178 in SK1, conserved as Asp308 in SK2) that have been shown to form three tight hydrogen bonds with charge stabilisation to the hydroxypyrrolidinium subunit of PF-543 in its SK1 co-crystal structure. ${ }^{38}$

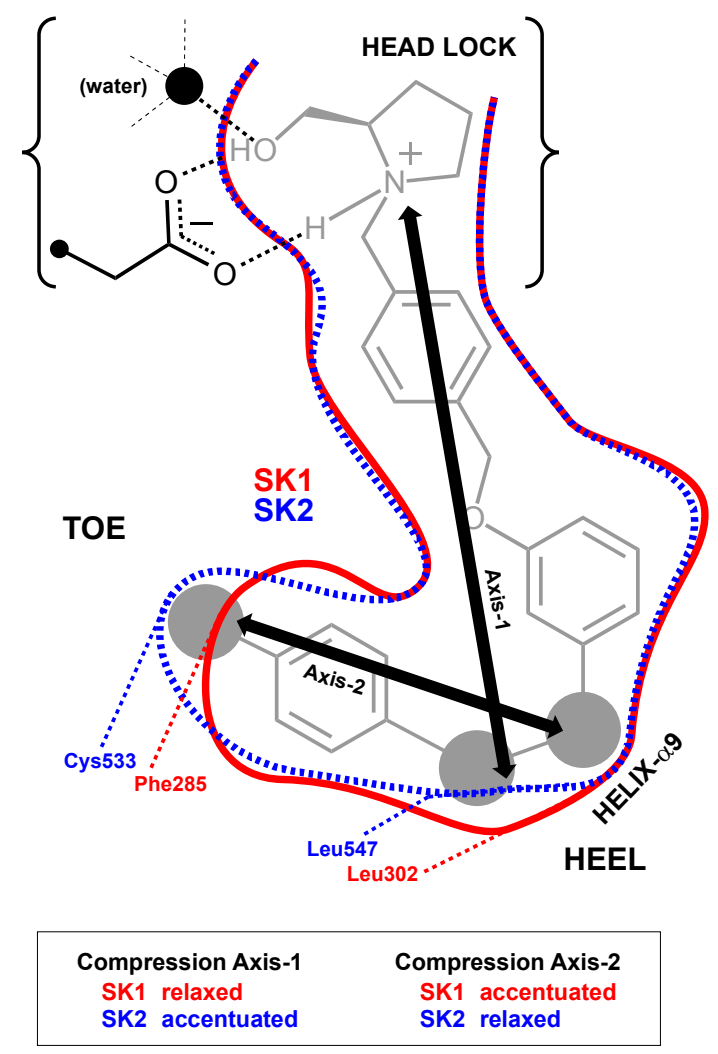

Figure 3. Key compression axes postulated to influence ligand binding to the J-channels of SK1 and SK2. 
The methyleneoxy-linked analogue (49) also exhibited near equipotent inhibitory activity against the two isoforms, but with a marginal increase in overall potency relative to the ethylenelinked compound (23). Thus, 49 exhibited $\mathrm{IC}_{50}$ values of 14 and $16 \mathrm{nM}$ against SK1 and SK2 respectively. However, replacement of the oxygen by a larger sulfur atom in compound $\mathbf{5 8}$ caused a 10-fold loss in potency against SK1 with only a slight loss $(<2$-fold) against SK2, thereby resulting in a compound with reversed selectivity (albeit modest) in favour of SK2 ( $\mathrm{IC}_{50}$ values of 137 and $26 \mathrm{nM}$ against SK1 and SK2 respectively). This was an important finding because it supported our second hypothesis, namely that the J-channel toe is likely expanded in SK2 or/and exhibits greater plasticity. Thus, compression along an axis linking the large sulfur atom and para position of the phenyl ring in $\mathbf{5 8}$ (Axis-2 in Figure 3) might be less severe in SK2 than in SK1. Indeed, analysis of our PF-543/SK1 co-crystal structure ${ }^{38}$ (Figure 2) had suggested a remarkably close fit for the phenylsulfonylmethylene tail unit of PF-543 in the SK1 J-channel, with the para$\mathrm{CH}$ packed against Phe288 and the methylene of the linker wedged against helix- $\alpha 9$. Conceivably, alleviation of compression between these two points (and associated ligand strain) might contribute to the enhanced inhibitory potency of sulfonate 19 over the sulfonylmethylene-linked analogue (18).

We next sought to exploit the hypothesised tighter compression axis between toe and heel in SK1 (Axis-2 in Figure 3) still further by installation of a substituent in the terminal phenyl ring of 49 and 58, with a particular focus on the para-position to see whether compounds with even greater selectivity for SK2 could be achieved. Given the potential differences in J-channel surface allied to the replacement of Ile174 in SK1 by Val304 in SK2, however, we also wished to examine the impact of substitution at the ortho- and meta-positions. For that reason, we evaluated fluorides 50-52 and chlorides 53-55 derived from methyleneoxy-linked parent 49. The standout feature 
with this compound set was indeed a pronounced loss in SK1-inhibitory potency for the parafluoro and para-chloro analogues ( 52 and 55), which showed $c a$. 12-fold and 295-fold increases in $\mathrm{IC}_{50}$ relative to 49 respectively. Some loss in potency against SK2 was also observed for these compounds ( $\leq 3$-fold relative to parent 49 ), but SK1 was preferentially penalised, leading to highly selective, nanomolar-potent SK2 inhibition in the case of chloride $\mathbf{5 5}$ (see concentration response curves in Figure 4). Curiously the para-fluoro analogue (52; SK2 $\mathrm{IC}_{50} 49 \mathrm{nM}$ ) showed equivalent or even rather more loss in SK2 potency relative to parent 49 (SK2 $\left.\mathrm{IC}_{50} 16 \mathrm{nM}\right)$ than its chloride counterpart (55; SK2 $\left.\mathrm{IC}_{50} 41 \mathrm{nM}\right)$. This outcome may reflect a requirement for some induced fit to accommodate the halogen in SK2. Thus, the cost associated with side chain perturbation caused by binding of the ligand might be offset by greater surface contact for the chloride over the fluoride.

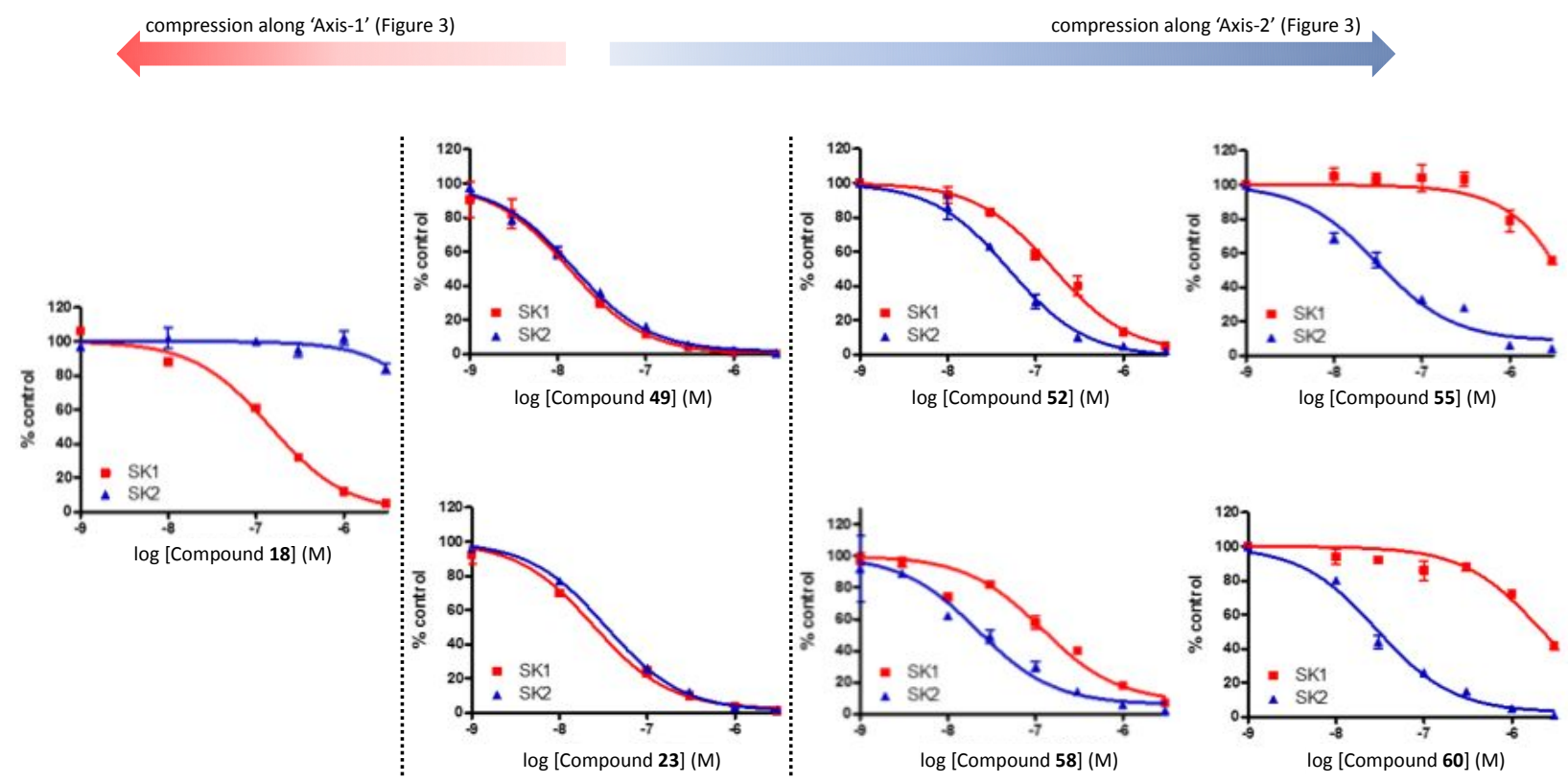

Figure 4. Selected SK1 and SK2 concentration response curves for PF-543-derived J-channel probes, highlighting the reversal of behaviour from SK1-selective inhibition (left) to SK2-selective 
inhibition (right) with ligand features that induce compression along Axis-1 and Axis-2 of Figure 3 respectively. (Assay conditions: see legend to Chart 2.)

In the case of the methylenesulfanyl-linked analogue (58), the effects of para-fluoro and para-chloro substitution $\mathbf{( 5 9 / 6 0 )}$ broadly mirror those seen in the methyleneoxy-linked series $(\mathbf{5 2} / \mathbf{5 5})$, where inhibition of SK1 but not SK2 is significantly penalised (Chart 2). Although differences in the size and bond angle preferences of the sulfide and ether linkages may subtly modulate terminal halogen fit to the J-channel toe and ligand strain, in both cases the presence of the larger chlorine atom afforded greatest isoform discrimination, with selectivity for inhibition of SK2 over SK1 in the range of 75-fold to 100-fold for $\mathbf{6 0}$ and 55. Introduction of bulkier or/and more polar para-substituents may be counterproductive for SK2 inhibitory performance however. Thus, in the methyleneoxy-linked series introduction of a methoxy group (compound 56, $\mathrm{SK} 2 \mathrm{IC}_{50}$ $119 \mathrm{nM}$ ) led to a 7-fold loss in SK2 inhibitory potency relative to parent $\mathbf{4 9}$ and a linear nitrile extension (compound 57, SK2 $\mathrm{IC}_{50} 1.12 \mu \mathrm{M}$ ) caused a 70-fold loss in activity. Whilst this fall off in inhibitory potency may reflect a limit to the capacity of the SK2 J-channel toe, changes in dipole and lipophilicity of the terminal subunit may also be factor in the activity fall off. Thus, a nitrile group is sometimes exploited as a bioisostere for the halogen in (hetero)aromatic chlorides, conferring a significant reduction in lipophilicity and, therefore, increased lipophilic ligand efficiency. ${ }^{45,}, 46$

In contrast to substitution at the para-position, the SK1-inhibitory activity of $\mathbf{4 9}$ is more tolerant of halogenation at the ortho- and meta-positions on the terminal arene (Chart 2, compounds 50, 51, 53 and 54). Here only modest activity loss (ca. 3-fold) is observed (50/53/54), whilst meta-fluorination even marginally enhances activity (51, SK1 $\left.\mathrm{IC}_{50} 9 \mathrm{nM}\right)$ relative to parent 
49 (SK1 IC $\mathrm{I}_{50} 14 \mathrm{nM}$ ). Interestingly SK2 is less tolerant of substitutions at the ortho- and metapositions, particularly at the latter site, where fluorination $\left(\mathbf{5 1}, \mathrm{SK} 2 \mathrm{IC}_{50} 143 \mathrm{nM}\right)$ and chlorination (54, SK2 $\mathrm{IC}_{50} 412 \mathrm{nM}$ ) produce respectively 9-fold and 26-fold activity loss versus parent 49 (SK2 $\mathrm{IC}_{50} 16 \mathrm{nM}$ ). These results suggest that the SK2 J-channel foot, whilst extended compared to SK1, is tighter in width, at least between certain points.

Structural inferences for the SK2 J-channel. Crystal structures of SK1 have only recently emerged (since 2013), whilst no structures are currently available for SK2. To facilitate qualitative rationalization of the isoform selectivity profiles of the ligands, we constructed an homology model for SK2 based on the crystal structure (4V24) of the large SK1 splice variant (SK1b, sometimes also called SK1c) with bound PF-543 that we had recently determined at $1.8 \AA$ resolution. ${ }^{38}$ In brief, an initial model was generated using the default automated routines of the SWISS-MODEL server ${ }^{47-50}$ and this was refined using the Small Molecule Drug Discovery software suite from Schrödinger, LLC. In particular, LBL-2 was remodelled from the structure of the corresponding loop in the Enterococcus faecalis diacylglycerol kinase family protein, as defined in the crystal structure 4WER (DOI: $10.2210 / \mathrm{pdb} 4 \mathrm{wer} / \mathrm{pdb}$ ). The rationale for this adjustment was that the C-terminal end of LBL-2 in SK2 (524-RFDDGL-529) has sequence features that are more closely related to prokaryotic diacylglycerol kinases than to SK1 (Figure S1 in Adams $\left.e a^{39}\right)$.

Our activity data for the normethyl analogue (18) of PF-543 suggested that the central ring methyl group in PF-543 is not a key SK2-discriminating feature and determinant of the high SK1inhibitory selectivity exhibited by PF-543. Nevertheless, we did find that energy minimisation of our ligand probe set docked into the SK2 model, as illustrated for $\mathbf{6 0}$ in Figure 5A, tended to result in contraction of the J-channel notch that hosts the PF-543 methyl. This notch is formed at the 
interface between helices- $\alpha 8$ and $-\alpha 9$ of the two flap-like LBL-1 and LBL-3 loops respectively ( $c f$.

Figure 1). As such, size and surface contouring of the notch may be sensitive to subtle changes in the seating of the two helices as well as to accessible conformational volumes of local residues. Indeed, inspection of an overlay of all protein chains from the currently available crystal structures revealed significant differences in the notch surface even across different SK1 structures, thus suggesting a degree of plasticity in this region of the J-channel (Figure 5B and 5C). A particularly important residue in this regard is Leu299 in SK1, which is located on helix- $\alpha 9$ and conserved in SK2 as Leu544 (marked in Figure 5). This residue exhibits some conformational variance across SK1 crystal structures and would expand the notch region in the SK2 model illustrated in Figure 5 to accommodate the PF-543 methyl group with only modest movement.

(A)

60/SK2 model

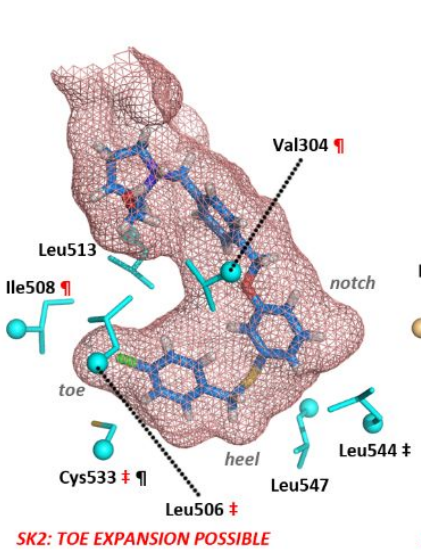

If sequence difference between SK1 / SK2 isoforms

† key conformationally restrained residu

₹ key conformationally mobile residue
(B)

PF-543/SK1 co-crystal structure

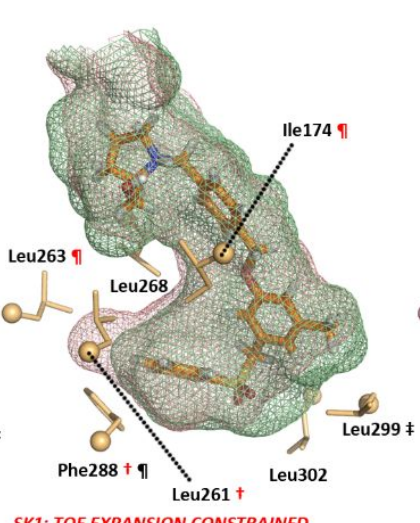

SK1: TOE EXPANSION CONSTRAINED
(C)

SKi/SK1 co-crystal structure
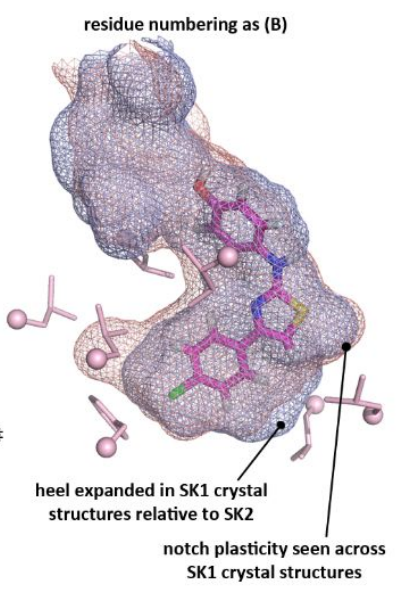

(D)

overlay (A)-(C)

residue numbering as (A) and (B)

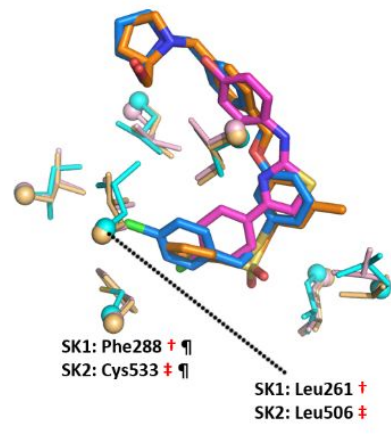

Figure 5. Comparison of modelled binding mode for SK2-selective inhibitor $\mathbf{6 0}$ with SK1 cocrystal structures of PF-543 (1) and SKi (10). Panel (A): 60 (blue stick) docked into SK2 model (red mesh), highlighting key contact residues (cyan stick) and expanded SK2 J-channel toe surface. Panel (B): PF-543 (1; orange stick) is shown from its co-crystal structure (4V24) with SK1 (green 
mesh) and the SK2 model surface (red mesh) overlaid from (A); SK1 contact residues are shown (light orange stick) and the constrained SK1 J-channel toe surface is evident. Panel (C): As (B), but showing co-crystal structure (3VZD) of SKi (10, magenta stick) with SK1 (blue mesh and pink stick key contact residues) superimposed onto the SK2 model (red mesh) from panel (A); the heel region adjacent to SK1 Leu302 is consistently less compressed in SK1 structures (relative to the SK2 model), whilst the notch surface exhibits some plasticity. Panel (D): overlay of (A)-(C) minus the J-channel surface; the chlorine atom of $\mathbf{6 0}$ is accommodated in SK2 between Cys533 and Leu506, with rotation of the latter possible whilst the cognate SK1 residue (Leu261) is constrained by the packing of adjacent residues.

Although the notch region exhibits significant plasticity, inspection of the SK1 J-channel across different crystal structures revealed that the protein surface is quite tightly defined (irrespective of ligand occupancy) both around the J-channel heel that contacts the PF-543 sulfonyl group and around the toe that interfaces with the end of the PF-543 terminal phenyl subunit. Our data indicate that sulfonyl replacement by methylene in compounds 23 and 49 enhances SK1inhibitory potency compared to the sulfonylmethylene-linked parent (18), which suggests that the sulfonylmethylene linker is already a little oversized for an optimal fit of the tail of the ligand to the SK1 J-channel. Thus, only a modest additional contraction in the SK2 J-channel at this point could generate a strongly unfavourable compressive effect for compounds such as PF-543 and its normethyl analogue (18) to account for their SK1 selectivity. The SK2 model supported the proposal that the SK2 J-channel may be contracted in the heel region, in particular due to inwards movement of Leu547 (corresponding to Leu302 in SK1), Figure 6A. However, the model also suggested that the basis for such movement may be a consequence, at least in part, of differences 
in the LBL-2/LBL-3 interfaces of the isoforms and not merely due to local residue differences immediately surrounding the leucine, as we had first conceived (Figure 2). In particular, Leu547 is located on helix- $\alpha 9$ in LBL-3, and the C-terminal end of this helix engages the hairpin-like tip of LBL-2 (Figure 6a). The model suggested that residue differences in LBL-2 might promote an inward movement at the C-terminus of helix- $\alpha 9$, thereby exerting leverage on the J-channel heel through Leu547. As the key heel compression contact is against the $C \beta$ atom of Leu547, rather than the end of the side chain, the leverage cannot be alleviated by side chain rotation. However, compounds with reduced steric demand in the heel ( 23 and 49$)$ can be accommodated in both SK1 and SK2 (illustrated for 49 in Figure 6B and 6C).

(A)

LBL-2 / LBL-3 structure

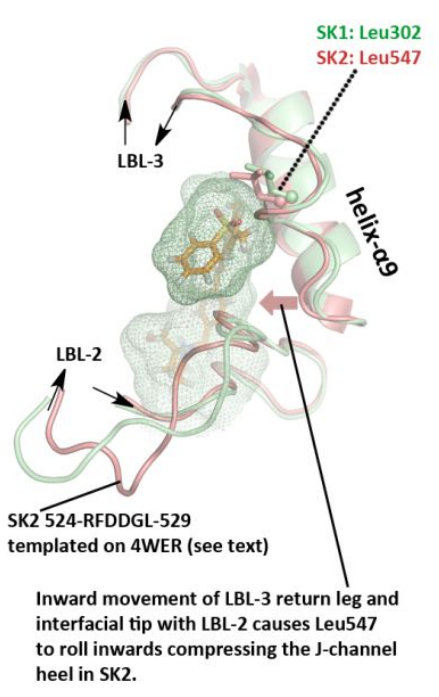

(B)

49/SK2 model

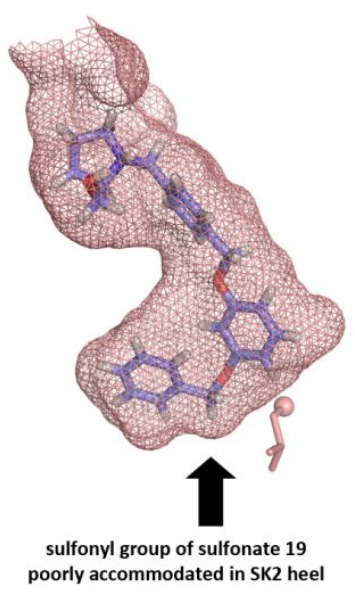

(C)

49/SK1 model

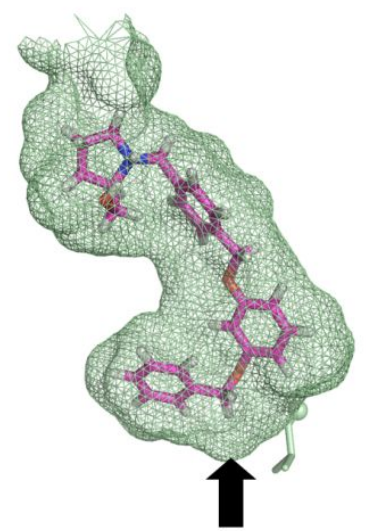

sulfonyl group of sulfonate 19 well accommodated in SK1 heel
(D)

overlay (B) and (C)

Figure 6. The J-channel heel is a key determinant of isoform discrimination by SK inhibitors. Panel (A): LBL-2 and LBL-3 are shown from the co-crystal structure (4V24) of PF-543 (orange stick) with SK1 (green ribbon); the corresponding elements from our SK2 homology model (red ribbon) are overlaid, illustrating inward movement in LBL-3 leading to heel compression in SK2 by Leu547. Panel (B): Potent unselective inhibitor 49 (blue stick) is shown modelled into the SK2 
J-channel (red mesh); the J-channel heel surface is driven significantly inwards relative to SK1 so that the presence of a sulfonyl group in the ligand $(49 \rightarrow 19,56$-fold activity loss) is poorly tolerated by SK2. Panel (C): Inhibitor 49 (magenta stick) is again shown, here modelled into the SK1 J-channel (green mesh); the SK1 J-channel heel surface exhibits less compression and accommodates a sterically more demanding sulfonyl containing linker more readily $(\mathbf{4 9} \rightarrow \mathbf{1 9}$, no activity loss; $\mathbf{2 3} \rightarrow \mathbf{1 8}, 5$-fold activity loss). Panel (D): overlay of (B) and (C) minus the J-channel surface.

The model also suggested that the strong SK2 selectivity of the para-halo derivatives of 49/58 is indeed likely due to J-channel toe surface expansion, but that this may not be solely due to the single amino acid substitution of Phe288 in SK1 by Cys533 in SK2 (Figure 2). Indeed, in the absence of halogen substituents on the ligand, the energy minimised SK2 model complexes showed little apparent expansion in the toe surface compared to SK1, as illustrated for 49 docked to SK2 and SK1 (Figure 6B and 6C respectively). The key to accommodation of the para-halo atom appears to be perturbation in the conformation of an adjacent leucine (Leu506 in SK2, conserved in SK1 as Leu261) that packs against the cysteine. The combination of Cys533 and Leu506 generates the toe surface in SK2 (Figure 5), with movement of the latter predicted to allow expansion to accommodate the chlorine of $\mathbf{5 5 / 6 0}$. The leucine additionally packs against two other non-conserved residues_-Val304 (Ile174 in SK1) and Ile508 (Leu263 in SK1) — and our model suggests that loosened packing with these residues and the cysteine may confer greater plasticity in the toe of the SK2 J-channel than in SK1. Thus, ligand binding in SK2 may involve an element of induced fit in the J-channel toe, potentially with an associated energy cost that is more or less offset depending on the effectiveness of surface contact between the ligand and the expanded toe. 
In contrast, the toe of the SK1 J-channel is likely to be more rigid and introduction of parasubstitution in the ligand is predicted to generate an unfavourable compression between the Jchannel toe and helix- $\alpha 9$, as illustrated in Figure 7 for chloride 60. Despite the enhanced plasticity and capacity indicated for the SK2 J-channel toe, our results nevertheless indicate significant limitations on the size of the para-substituent that can be accommodated in SK2. Thus, the axis of the para-substituent is predicted to orientate directly at the $C \beta$ atom of Ile508 presented from the SK2 CTD $\beta$-sandwich core, Figure 5A. In the case of chloride $\mathbf{6 0}$, a distance of $c a .4 .3 \AA$ is predicted between Ile508 C $\beta$ and the chlorine atom, and this spatial constraint likely contributes to the sharp drop in inhibitory potency against SK2 seen with the introduction of a para-cyano group in 57.

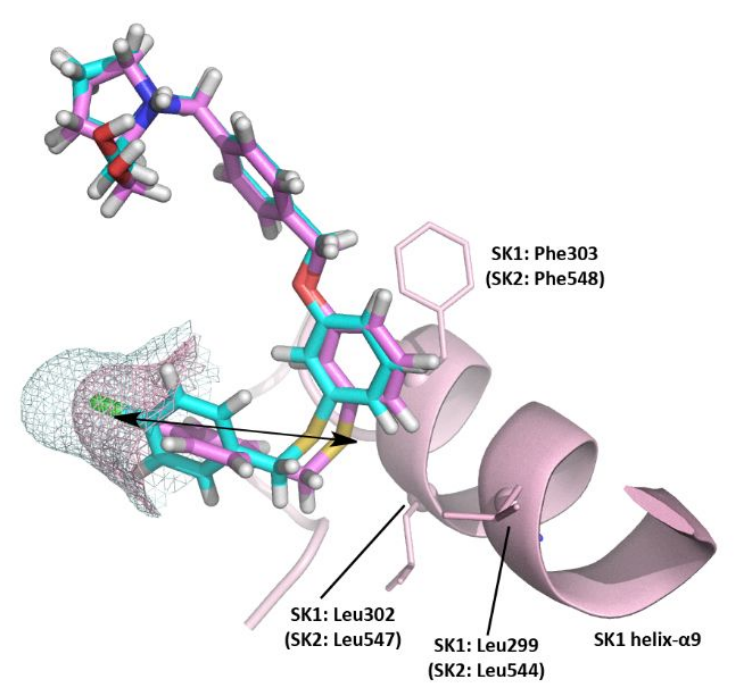

Figure 7. The J-channel toe is a second key determinant for isoform discrimination by SK inhibitors. A comparison of modelled binding modes for the SK2-selective inhibitor (60) is shown here, with the SK2-docked inhibitor (cyan stick) superimposed onto the SK1-docked inhibitor (magenta stick). With reduced plasticity in the SK1 J-channel toe (pink mesh), the sulfur atom of $\mathbf{6 0}$ is predicted to be tightly wedged against the backbone of helix- $\alpha 9$ (pink ribbon). This generates 
an unfavourable compression axis (black arrow, corresponding to 'Axis-2' of Figure 3) that preferentially penalizes binding to SK1. In SK2 the greater plasticity of the J-channel toe (cyan mesh) is predicted to allow accommodation of $\mathbf{6 0}$ with less compression.

During the course of our work, Childress et $a^{36}$ described a series of pyrrolidine carboximidamide SK inhibitors with a spectrum of SK1- and SK2-inhibitory selectivity. The highest SK2-selectivity was seen with compound $\mathbf{9}$, which is notable for its extended tail structure. With the guanidinium head group engaging key acidic residues in the mouth of the J-channel, the aminothiazole subunit in $\mathbf{9}$ would be expected to overlay the middle arene subunit of our ligands, whilst the oxadiazole ring of $\mathbf{9}$ would lie in plane and partially map onto the $p$-xylylene subunit (Figure 8B/C). However, an intriguing feature with such a binding mode is that the rod like biphenyl tail of 9 could only be accommodated if there is a significant expansion in the toe of the J-channel, and this on the other side of Cys533 to that occupied by the chlorine in $\mathbf{5 5 / 6 0}$. There are two key residue substitutions that may make this possible for SK2 but not readily achievable for SK1: one is the replacement of SK1 Phe288 by Cys533 in SK2; the second is the exchange of SK1 Met312 for Phe557 in SK2. In the absence of compound 9 the latter residue, which is surface exposed on LBL-3, is predicted to fold inwards towards the adjacent cysteine (in partial surrogacy for the Phe288 residue of SK1). Rotation of these two side chains alone (Cys533/Phe557) was sufficient to open an extended pocket in our model and accommodate the terminal phenyl group of 9 with a reasonably relaxed biphenyl torsion $\left(37^{\circ}\right)$ and favourable packing interactions against Cys533, Phe557 and other aromatic residues (Tyr, His). This postulated binding mode for 9, in effect, amounts to tunnelling between LBL-2 and LBL-3 in SK2. In SK1 the more rigid J-channel toe is stoppered by Phe288, for which a rotation analogous to that required of Cys533 in SK2 is 
sterically precluded. The suggested binding mode for ligand 9 would also avoid encroachment on the Leu547 heel compression point in SK2 that we propose biases inhibitor selectivity towards SK1. Binding of compound 9 to SK1 would require much more extensive perturbation to the protein structure and packing of the LBL-3 return leg.
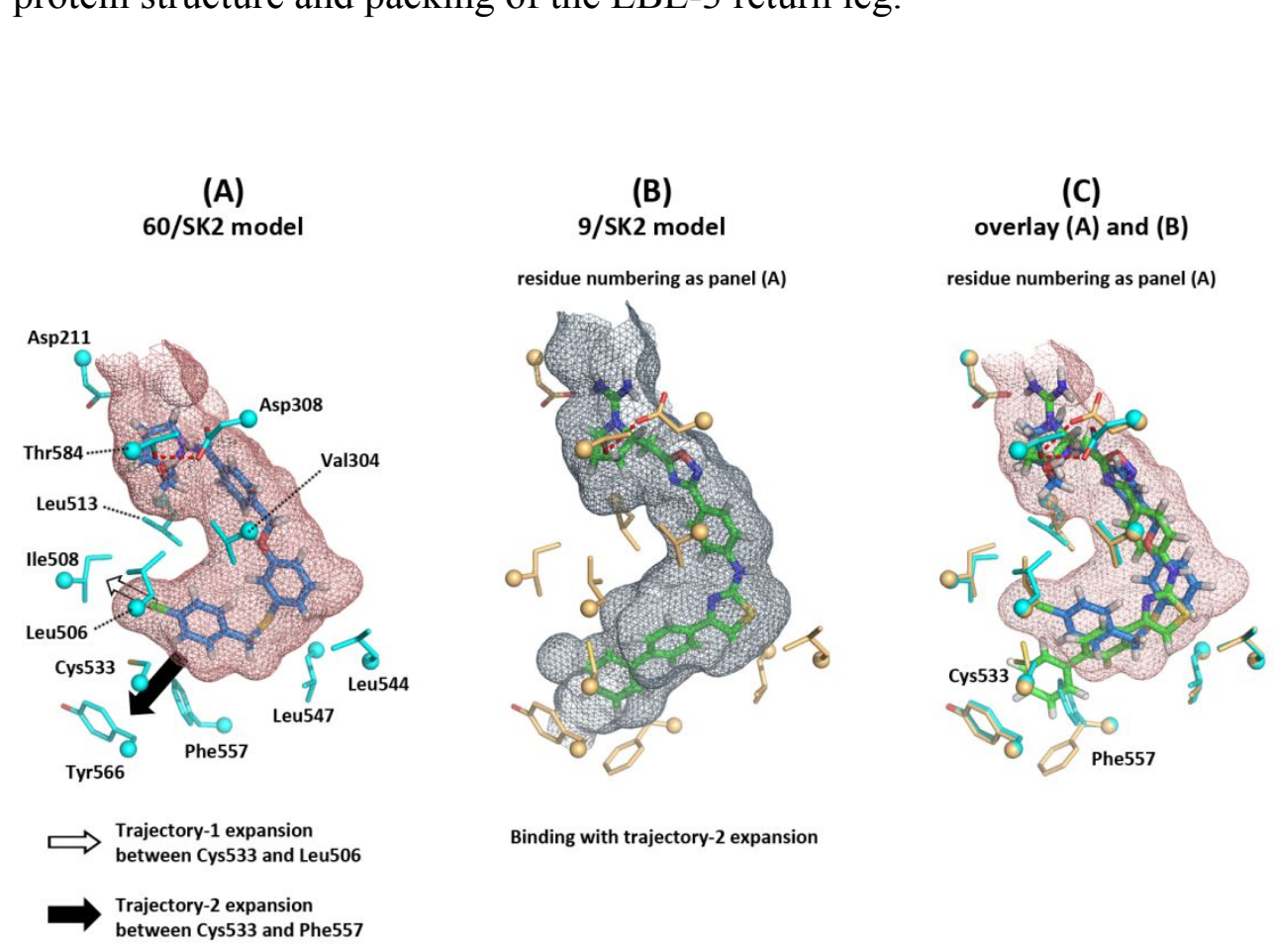

Binding with trajectory-2 expansion

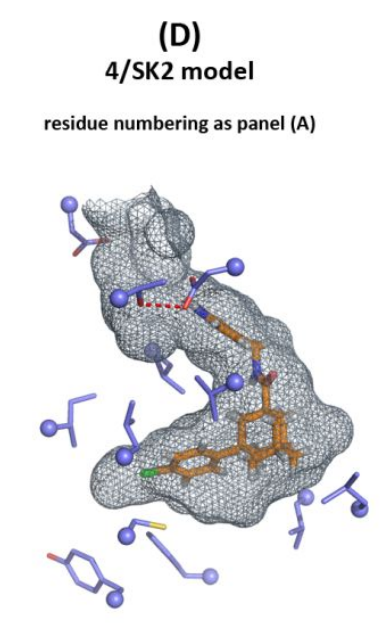

Figure 8. Plasticity in the J-channel toe of SK2 may be exploited to develop SK2-selective inhibitors. Panel (A): Compound 60 (blue stick) docked into the SK2 model (red mesh), highlighting key contact residues (cyan stick) and two predicted trajectories for possible toe expansion (arrows). Small groups may be accommodated between Cys533 and Leu506 (Trajectory-1, hollow arrow). This is the predicted expansion for binding of $\mathbf{5 5 / 6 0}$, where the fit of the $\mathrm{Cl}$ atom is likely made possible largely by rotation in Leu506. Larger groups may be accommodated between Cys533 and Phe557 (Trajectory-2, filled arrow) upon rotation of these side chains. Panel (B): VT-20dd (9, green stick) docked into the SK2 model (grey mesh), highlighting key contact residues (orange stick). Here the ligand is predicted to exploit the second toe expansion trajectory. Panel (C): Overlay of (A) and (B) showing the SK2 J-channel surface 
for docked 60 (red mesh) and illustrating the two key residue rotations in Cys533 and Phe557 required for Trajectory-2 expansion (cyan stick $\rightarrow$ orange stick positions). Panel (D): ABC294640 (4, orange stick) docked into SK2 (grey mesh). In this model, the Trajectory-1 expansion is made possible chiefly by rotation of Cys533 rather than Leu506, but the space generated by the expansion is underused by the $\mathrm{Cl}$ atom.

Although our analysis suggests that outward rotation of Phe557 might allow tunnelling of substantially extended ligand tail groups in SK2 (Figure 8C), the preferred orientation of the Phe557 side chain (in the absence of such ligand extensions) is predicted to lie inwards towards Cys533 to maximise surface contact with adjacent hydrophobic residues. In this tightly packed inward orientation, the end of the Phe557 side chain is predicted to come into close contact with the meta-position of the terminal phenyl ring of our PF-543-derived ligands series. This might contribute to the poor tolerance by SK2 of meta-halogenation, as seen with $\mathbf{5 1}$ and $\mathbf{5 4}$ (vide supra). In SK1 the cognate residue (Met312, Figure 2) is more flexible and exhibits less reach compared to Phe557 in SK2, which is consistent with the greater tolerance towards meta-halogenation in $\mathbf{5 1}$ and 54. A suitable tail extension to enable tunnelling in SK2 ('Trajectory-2' in Figure 8) may require a large group to provoke the necessary rotation in Phe557 and compensate for the loss of packing interactions between this residue and adjacent side chains. Whilst potentially interesting for future investigation, our objective here was to achieve selectivity control with conservative changes in the parent ligand structure, thereby keeping molecular weight within druglike bounds.

We also docked ABC294640 (4) into our SK2 model for comparison (Figure 8D). In this case we found that the pyridyl group closely overlays the $p$-xylylene subunit of our ligands whilst the adamantyl group sits well in the J-channel bend-partly overlaying the middle arene of our 
compounds but also the tail linker (and again without encroaching severely on the Leu547 heel compression point). The plane of the terminal chlorophenyl group was slightly rotated relative to $\mathbf{5 5 / 6 0}$, but the chlorine atom occupied a similar position to that proposed for the chlorine in our SK2-selective compound, $\mathbf{5 5}$.

\section{CONCLUSIONS}

Growing interest in the therapeutic potential of targets within the sphingolipid signalling pathway is fueling efforts to develop isoform-selective SK inhibitors across a range of chemotypes. ${ }^{51-53} \mathrm{PF}$ 543 has attracted significant attention as a nanomolar-potent SK1-selective inhibitor. However, a structural basis for the compound's SK1-over-SK2 selectivity has not been described until now, despite the recent disclosure of activity data for additional analogues. ${ }^{35}$ Moreover, a lack of discriminating nanomolar-potent SK2-selective inhibitors as signalling pathway probes has hindered thorough exploration of the pharmacological potential of SK2 as a distinct target to date. From a clinical perspective, the most advanced compound remains the micromolar-potent, SK2selective inhibitor, $\mathrm{ABC} 294640$ (4). However, the biological activity of this compound is complicated because it is a modulator of dihydroceramide desaturase and induces the proteasomal degradation of SK1. ${ }^{31-33}$

In order to develop a qualitative structural rationale for the design of isoform-selective inhibitors, we mapped SK2 sequence differences onto our recently determined ${ }^{38}$ SK1/PF-543 cocrystal structure. That analysis (Figure 2) suggested a focus on the heel and toe of the J-channel, which we then probed with a concise set of PF-543 analogues modified in the tail linker and terminal phenyl ring (Chart 2). Our studies indicate that the phenyl group of PF-543, which is tightly fitted to the toe of the ligand-binding J-channel, constrains placement of the sulfonyl 
oxygens of the ligand into a region of surface encroachment in the J-channel heel of SK2. Deleting the sulfonyl oxygens by installation of replacement linkers for the PF-543 sulfonylmethylene group endows the ligand with dual SK1/SK2-inhibitory activity $(\mathbf{2 3}, \mathbf{4 9}, \mathbf{5 8})$. In contrast to the heel, our work suggests that the surface of the J-channel toe in SK2 may be expanded and exhibit greater plasticity compared to SK1. We have shown that this difference may be exploited with a suitably positioned halogenated terminal arene in the ligand to undermine inhibition of SK1. Coupled with replacement of the PF-543 sulfonylmethylene linker, this strategy allows full reversal in the SK isoform selectivity profile to be engineered, with up to 100 -fold selectivity for SK2 over SK1 achieved in our series with $p$-chlorophenyl terminal ligand subunits. Comparative analysis of another recently disclosed SK2-selective inhibitor $(9)^{36}$ suggests an additional tail trajectory where ligand extensions may be accommodated through plasticity in SK2 that does not exist in SK1. Taken together, we suggest that these studies now provide a blueprint for rational design of isoform-selective SK inhibitors and the development of suitable tool compounds for further exploring the pharmacological potential of SK2 as a therapeutic target.

\section{EXPERIMENTAL SECTION}

SK1 and SK2 assays. Sphingosine kinase assays employed purified SK1 or purified SK2 (40-180 ng/ml) and were performed using the $K_{m}$ concentrations of Sph (3 and $10 \mu \mathrm{M}$, respectively) and $250 \mu \mathrm{M}\left[\gamma^{-32} \mathrm{P}\right] \mathrm{ATP}(0.75 \mathrm{kBq} / \mathrm{nmol})$ for $30 \mathrm{~min}$ at $30^{\circ} \mathrm{C}$ in a buffer containing $20 \mathrm{mM}$ Tris (pH 7.4), $1 \mathrm{mM}$ EDTA, $1 \mathrm{mM} \mathrm{Na}_{3} \mathrm{VO}_{4}, 40 \mathrm{mM} \beta$-glycerophosphate, $1 \mathrm{mM} \mathrm{NaF}$, 0.007\% (v/v) $\beta$-mercaptoethanol, 20\% (v/v) glycerol, $10 \mu \mathrm{g} / \mathrm{mL}$ aprotinin, $10 \mu \mathrm{g} / \mathrm{mL}$ soybean trypsin inhibitor, $1 \mathrm{mM}$ PMSF, $0.5 \mathrm{mM}$ 4-deoxypyridoxine (and $400 \mathrm{mM} \mathrm{KCl}$ in the case of SK2 assays). Sph was presented in Triton X-100 (final concentration, $0.063 \% \mathrm{w} / \mathrm{v}$ ) for SK1 whereas 
fatty acid free bovine serum albumin (final concentration, $0.2 \mathrm{mg} / \mathrm{mL}$ ) was used in SK2 assays. Inhibitors were dissolved and diluted in DMSO (5\% v/v final in assay). ${ }^{32} \mathrm{P}$-sphingosine 1phosphate was extracted with $500 \mu \mathrm{L}$ of 1-butanol, followed by a phase-split using $1 \mathrm{~mL}$ of $2 \mathrm{M}$ $\mathrm{KCl}$ and two washes of the lower (aqueous) phase, using $2 \mathrm{M} \mathrm{KCl}$, to remove unreacted $\left[\gamma-{ }^{32} \mathrm{P}\right] \mathrm{ATP}$ before harvesting the upper (organic) phase and quantification by Cerenkov counting.

Synthetic chemistry general methods. Solvents and reagents were procured from commercial suppliers (Acros, Geel, Belgium; Alfa Aesar, Heysham, United Kingdom; Apollo Scientific, Stockport, United Kingdom; Fisher Scientific, Loughborough, United Kingdom; Fluorochem, Hadfield, United Kingdom; Sigma-Aldrich, Gillingham, United Kingdom) and used as supplied without further purification unless otherwise stated. "Light petroleum" refers to the fraction boiling between 40 and $60{ }^{\circ} \mathrm{C}$. Analytical thin layer chromatography was carried out using aluminum backed plates coated with Merck Kieselgel 60 GF254 (No. 05554). Developed plates were visualized under ultraviolet light $(254 \mathrm{~nm}$ and $366 \mathrm{~nm})$ and/or by alkaline potassium permanganate dip. Preparative chromatography was performed (a) in conventional glass columns under flash column chromatography conditions (silica gel of 40-63 $\mu \mathrm{m}$ particle size from Fisher Scientific); or (b) using SP4 Biotage MPLC apparatus with silica gel of 40-63 $\mu \mathrm{m}$ particle size (Fisher Scientific) in $10 \mathrm{~g}$ or $50 \mathrm{~g}$ cartridges depending on the scale of material to be processed; or (c) using Strata ${ }^{\circledR}$ SI-1 cartridges (Phenomenex). Fully characterized compounds were chromatographically homogeneous. ${ }^{1} \mathrm{H}$ NMR spectra were recorded at $400 \mathrm{MHz}$ on JEOL Lambda Delta 400, Bruker AMX-400 and Bruker AVIII-400 spectrometers; ${ }^{13} \mathrm{C}$ NMR spectra were recorded at $101 \mathrm{MHz}$ on the same instruments. Chemical shifts are recorded in parts per million $(\delta$ in $\mathrm{ppm})$ and are referenced against solvent signals $\left(\delta_{\mathrm{C}} 77.16\right.$ for chloroform and $\delta_{\mathrm{C}} 39.52$ for methyl sulfoxide) for ${ }^{13} \mathrm{C}$ spectra and solvent residual resonances $\left(\delta_{\mathrm{H}} 7.26\right.$ for chloroform and $\delta_{\mathrm{H}}$ 
2.50 methyl sulfoxide) for ${ }^{1} \mathrm{H}$ spectra. ${ }^{54}{ }^{1} \mathrm{H}$ and ${ }^{13} \mathrm{C}$ chemical shift values are accurate to \pm 0.01 ppm and $\pm 0.1 \mathrm{ppm}$ respectively. $J$ values are given in $\mathrm{Hz}$. Multiplicity designations used are as follows: $\mathrm{s}, \mathrm{d}, \mathrm{t}, \mathrm{q}$, sept, and $\mathrm{m}$ for singlet, doublet, triplet, quartet, septet, and multiplet (respectively); br denotes an exchange-broadened signal. ${ }^{13} \mathrm{C}$ signal assignments, taken from distortionless enhancement by polarization transfer (DEPT) experiments, are listed in parenthesis. High-resolution mass spectroscopy (HRMS) was carried out under electrospray ionisation (ESI), in a Fourier transform analyser by Exactive ${ }^{\circledR}$ ThermoFisher Scientific instrument. All compounds subjected to enzyme assay evaluation were $\geq 95 \%$ pure as determined by HPLC analysis. HPLC Method (A): YMC hydrosphere $\mathrm{C}_{18} 5 \mu \mathrm{m} / 12 \mathrm{~nm}(150 \times 4.5 \mathrm{~mm})$ column under isocratic elution $\left[0.1 \% \mathrm{CF}_{3} \mathrm{CO}_{2} \mathrm{H}\right.$ in $35 / 65$ water $\left./ \mathrm{MeCN}\right]$ at $0.7 \mathrm{~mL} / \mathrm{min}$ and $40{ }^{\circ} \mathrm{C}$ with detection at $\lambda 230 \mathrm{~nm}$. HPLC Method (B): Poroshell $120 \mathrm{C}_{18} 2.7 \mu \mathrm{m}(75$ x $4.6 \mathrm{~mm})$ column under gradient elution from $95 \%$ water $\left(5 \mathrm{mM} \mathrm{NH}_{4} \mathrm{OAc}\right)$ and $5 \% \mathrm{MeCN}\left(5 \mathrm{mM} \mathrm{NH}_{4} \mathrm{OAc}\right)$ to $100 \% \mathrm{MeCN}\left(5 \mathrm{mM} \mathrm{NH}_{4} \mathrm{OAc}\right)$ at $1 \mathrm{~mL} / \mathrm{min}$ and $40{ }^{\circ} \mathrm{C}$ with detection at $\lambda 214 \mathrm{~nm}$.

1-Methoxy-3-((phenylsulfonyl)methyl)benzene (12). A mixture of 11 (7.58 g, 37.7 $\mathrm{mmol})$, sodium benzene sulfinate $\left(\mathrm{NaSO}_{2} \mathrm{Ph}, 6.75 \mathrm{~g}, 41.1 \mathrm{mmol}\right)$ and Aliquat ${ }^{\circledR} 336(0.28 \mathrm{~g}, 0.70$ mmol) was stirred at $85^{\circ} \mathrm{C}$ for $18 \mathrm{~h}$. The reaction mixture was diluted with hot EtOAc $(120 \mathrm{~mL})$, stirred at ambient temperature for $1 \mathrm{~h}$ and the resulting slurry filtered through Celite ${ }^{\circledR}$ to afford a filtrate that was concentrated in vacuo. The residue was subjected to flash column chromatography (light petroleum/EtOAc gradient 4:1 to 1:1) to afford 12 (4.61 g, 47\%) as a white powder. ${ }^{1} \mathrm{H}$ NMR $\left(400 \mathrm{MHz}, \mathrm{CDCl}_{3}\right) \delta 3.71(\mathrm{~s}, 3 \mathrm{H}), 4.28(\mathrm{~s}, 2 \mathrm{H}), 6.61(\mathrm{t}, J=2.2 \mathrm{~Hz}, 1 \mathrm{H}), 6.64(\mathrm{ddd}, J=7.4,1.6$, $1.0 \mathrm{~Hz}, 1 \mathrm{H}), 6.85(\mathrm{ddd}, J=8.3,2.6,1.0 \mathrm{~Hz}, 1 \mathrm{H}), 7.16(\mathrm{t}, J=7.9 \mathrm{~Hz}, 1 \mathrm{H}), 7.44-7.48(\mathrm{~m}, 2 \mathrm{H}), 7.58-$ $7.63(\mathrm{~m}, 1 \mathrm{H}), 7.64-7.67(\mathrm{~m}, 2 \mathrm{H})$. 
3-((Phenylsulfonyl)methyl)phenol (14). To a solution of $12(1.31 \mathrm{~g}, 5.00 \mathrm{mmol})$ in anhydrous $\mathrm{CH}_{2} \mathrm{Cl}_{2}(30 \mathrm{~mL})$ at $-78{ }^{\circ} \mathrm{C}$ under $\mathrm{N}_{2}$ was added dropwise $\mathrm{BBr}_{3}\left(1 \mathrm{M}^{\text {in } \mathrm{CH}_{2} \mathrm{Cl}_{2} ; 5.50}\right.$ $\mathrm{mL}, 5.50 \mathrm{mmol})$. The mixture was allowed to come to ambient temperature over $2 \mathrm{~h}$ and then cooled to $0^{\circ} \mathrm{C}$ and quenched with saturated $\mathrm{NaHCO}_{3}(40 \mathrm{~mL})$. The separated aq. phase was back extracted with $\mathrm{CH}_{2} \mathrm{Cl}_{2}(2 \times 30 \mathrm{~mL})$. The combined organics were washed with brine $(2 \times 15 \mathrm{~mL})$, dried $\left(\mathrm{Na}_{2} \mathrm{SO}_{4}\right)$ and filtered. The filtrate was evaporated and the resulting residue subjected to flash column chromatography $\left(\mathrm{CH}_{2} \mathrm{Cl}_{2} / \mathrm{MeOH}\right.$ gradient $99.5: 0.5$ to $\left.99: 1\right)$ to afford 14 (958 $\left.\mathrm{mg}, 77 \%\right)$ as a white powder. ${ }^{1} \mathrm{H}$ NMR $\left(400 \mathrm{MHz}, \mathrm{CDCl}_{3}\right) \delta 4.26(\mathrm{~s}, 2 \mathrm{H}), 4.88(\mathrm{~s}, 1 \mathrm{H}), 6.58$ (ddd, $J=7.6,1.6$, $0.9 \mathrm{~Hz}, 1 \mathrm{H}), 6.66(1 \mathrm{H}$, app. t, $J$ 2.0), $6.79(\mathrm{ddd}, J=8.2,2.6,0.9 \mathrm{~Hz}, 1 \mathrm{H}), 7.10(\mathrm{t}, J=7.9 \mathrm{~Hz}, 1 \mathrm{H})$, 7.44-7.49 (m, 2H), 7.59-7.63 (m, 1H), 7.65-7.68 (m, 2H).

3-Hydroxyphenyl benzenesulfonate (15). A mixture of resorcinol (500 mg, $4.54 \mathrm{mmol}$ ), $\mathrm{K}_{2} \mathrm{CO}_{3}(1.88 \mathrm{~g}, 13.6 \mathrm{mmol})$ and phenylsulfonyl chloride $(637 \mu \mathrm{L}, 4.99 \mathrm{mmol})$ in $\mathrm{MeCN}(6 \mathrm{~mL})$ was stirred at ambient temperature for $16 \mathrm{~h}$. The mixture was partitioned between $\mathrm{Et}_{2} \mathrm{O}$ and water, and the separated organic phase then washed with saturated $\mathrm{K}_{2} \mathrm{CO}_{3}$ solution and extracted with 1 $\mathrm{M} \mathrm{NaOH}$ (aq). The aqueous extract was acidified with $3 \mathrm{M} \mathrm{HCl}$ (aq) and back extracted with $\mathrm{Et}_{2} \mathrm{O}$. The organic phase was dried $\left(\mathrm{MgSO}_{4}\right)$ and evaporated to afford $15(244 \mathrm{mg}, 21 \%)$ as a beige solid. ${ }^{1} \mathrm{H}$ NMR (400 MHz, DMSO- $\left.d_{6}\right) \delta 6.37-6.47(\mathrm{~m}, 2 \mathrm{H}), 6.69(\mathrm{dd}, J=8.1,1.5 \mathrm{~Hz}, 1 \mathrm{H}), 7.11-7.15$ (m, 1H), 7.65-7.69 (m, 2H), $7.81(\mathrm{t}, J=7.5 \mathrm{~Hz}, 1 \mathrm{H}), 7.86(\mathrm{~d}, J=7.6 \mathrm{~Hz}, 2 \mathrm{H}), 9.87$ (br s, 1H). ${ }^{13} \mathrm{C}$ NMR (101 MHz, DMSO- $\left.d_{6}\right) \delta 106.2,109.0,112.1,114.5,128.1,128.1,129.7,134.9,149.8,158.5$. 4-((3-((Phenylsulfonyl)methyl)phenoxy)methyl)benzaldehyde (16). A stirred mixture of 14 (283 mg, $1.14 \mathrm{mmol}$ ), 4-(bromomethyl)benzaldehyde (239 mg, $1.20 \mathrm{mmol}$ ) and $\mathrm{K}_{2} \mathrm{CO}_{3}(440$ $\mathrm{mg}, 3.19 \mathrm{mmol})$ in $\mathrm{MeCN}(8.0 \mathrm{~mL})$ was heated at $60^{\circ} \mathrm{C}$ for $3 \mathrm{~h}$. The mixture was filtered through Celite ${ }^{\circledR}$ to afford a filtrate that was concentrated in vacuo. The residue was partitioned between 
EtOAc $(50 \mathrm{~mL})$ and water $(20 \mathrm{~mL})$. The organic phase was washed with brine $(15 \mathrm{~mL})$, dried $\left(\mathrm{MgSO}_{4}\right)$ concentrated and processed by flash column chromatography $\left(\mathrm{CH}_{2} \mathrm{Cl}_{2}\right.$ to $0.5 \%$ $\mathrm{MeOH} / \mathrm{CH}_{2} \mathrm{Cl}_{2}$ gradient elution) to afford $16(338 \mathrm{mg}, 81 \%)$ as a white powder. ${ }^{1} \mathrm{H}$ NMR (400 $\left.\mathrm{MHz}, \mathrm{CDCl}_{3}\right) \delta 4.28(\mathrm{~s}, 2 \mathrm{H}), 5.07(\mathrm{~s}, 2 \mathrm{H}), 6.65(\mathrm{ddd}, J=7.5,1.6,0.9 \mathrm{~Hz}, 1 \mathrm{H}), 6.78(\mathrm{dd}, J=2.5$, $1.6 \mathrm{~Hz}, 1 \mathrm{H}), 6.92(\mathrm{ddd}, J=8.3,2.6,1.0 \mathrm{~Hz}, 1 \mathrm{H}), 7.16(\mathrm{dd}, J=8.3,7.6 \mathrm{~Hz}, 1 \mathrm{H}), 7.43-7.48(\mathrm{~m}$, 2H), 7.55-7.58 (m, 2H), 7.58-7.63 (m, 1H), 7.63-7.67 (m, 2H), 7.89-7.92 (m, 2H), $10.03(\mathrm{~s}, 1 \mathrm{H})$. ${ }^{13} \mathrm{C}$ NMR $\left(101 \mathrm{MHz}, \mathrm{CDCl}_{3}\right) \delta 62.8\left(\mathrm{CH}_{2}\right), 69.2\left(\mathrm{CH}_{2}\right), 115.6(\mathrm{CH}), 117.0(\mathrm{CH}), 123.9(\mathrm{CH})$, $127.5(2 \times \mathrm{CH}), 128.6(2 \times \mathrm{CH}), 128.9(2 \times \mathrm{CH}), 129.6(\mathrm{C}), 129.7(\mathrm{CH}), 133.1(\mathrm{CH}), 130.0(2 \times \mathrm{CH})$, $136.1(\mathrm{C}), 138.0(\mathrm{C}), 143.6(\mathrm{C}), 158.4(\mathrm{C}), 191.8(\mathrm{CO})$.

3-((4-Formylbenzyl)oxy)phenyl benzenesulfonate (17). Following the procedure for 16, phenol 15 (150 mg, $0.568 \mathrm{mmol})$ afforded 17 (196 mg, 88\%) as a colourless solid. ${ }^{1} \mathrm{H}$ NMR (400 MHz, DMSO- $\left.d_{6}\right) \delta 5.16(\mathrm{~s}, 2 \mathrm{H}), 6.62(\mathrm{ddd}, J=8.1,2.2,0.8 \mathrm{~Hz}, 1 \mathrm{H}), 6.69-6.70(\mathrm{~m}, 1 \mathrm{H}), 6.99$ (ddd, $J=8.4,2.5,0.8 \mathrm{~Hz}, 1 \mathrm{H}), 7.27-7.31(\mathrm{~m}, 1 \mathrm{H}), 7.60(\mathrm{~d}, J=8.1 \mathrm{~Hz}, 2 \mathrm{H}), 7.66(\mathrm{dd}, J=8.2,7.5 \mathrm{~Hz}$ 2H), 7.77-7.84 (m, 1H), $7.86(\mathrm{dd}, J=8.2,1.3 \mathrm{~Hz}, 2 \mathrm{H}), 7.93(\mathrm{~d}, J=8.1 \mathrm{~Hz}, 2 \mathrm{H}), 10.02(\mathrm{~s}, 1 \mathrm{H}) .{ }^{13} \mathrm{C}$ NMR $\left(101 \mathrm{MHz}, \mathrm{DMSO}-d_{6}\right) \delta 68.9,108.9,114.1,114.3,127.8,128.2,129.7,129.7,130.5,134.2$, $135.0,135.7,143.3,149.8,158.8,192.8$.

\section{(R)-(1-(4-((3-((Phenylsulfonyl)methyl)phenoxy)methyl)benzyl)pyrrolidin-2-}

yl)methanol (18). To a solution of $16(96 \mathrm{mg}, 0.262 \mathrm{mmol})$ and $(R)-(-)-2$-pyrrolidinemethanol (28 $\mu \mathrm{L}, 0.287 \mathrm{mmol})$ in 1,2-dichloroethane $(2 \mathrm{~mL})$ was added $\mathrm{NaBH}(\mathrm{OAc})_{3}(83 \mathrm{mg}, 0.393 \mathrm{mmol})$. The mixture was stirred at ambient temperature for $16 \mathrm{~h}$. A further portion of $\mathrm{NaBH}(\mathrm{OAc})_{3}(28$ mg, $0.13 \mathrm{mmol}$ ) was added and stirring continued for $18 \mathrm{~h}$ until complete consumption of 16 was observed by TLC analysis $\left(\mathrm{CH}_{2} \mathrm{Cl}_{2} / \mathrm{MeOH} 9: 1\right)$. The mixture was diluted with $\mathrm{CH}_{2} \mathrm{Cl}_{2}(30 \mathrm{~mL})$ and washed with saturated $\mathrm{NaHCO}_{3}$ solution $(10 \mathrm{~mL})$. The organic phase was dried $\left(\mathrm{MgSO}_{4}\right)$, 
evaporated and the resulting residue subjected to flash column chromatography (gradient elution, $1 \%$ to $5 \% \mathrm{MeOH}$ in $\mathrm{CH}_{2} \mathrm{Cl}_{2}$ ) to afford $18\left(84 \mathrm{mg}, 71 \%\right.$ ) as a white powder. ${ }^{1} \mathrm{H}$ NMR (400 MHz, $\left.\mathrm{CDCl}_{3}\right) \delta 1.65-1.75(\mathrm{~m}, 2 \mathrm{H}), 1.80-1.88(\mathrm{~m}, 1 \mathrm{H}), 1.88-1.99(\mathrm{~m}, 1 \mathrm{H}), 2.30(\mathrm{q}, J=8.4 \mathrm{~Hz}, 1 \mathrm{H})$, 2.40-3.00 (br s, 1H), 2.72-2.78 (m, 1H), 2.96-3.01 (m, 1H), $3.38(\mathrm{~d}, J=13.0 \mathrm{~Hz}, 1 \mathrm{H}), 3.44$ (dd, $J=10.8,2.2 \mathrm{~Hz}, 1 \mathrm{H}), 3.66(\mathrm{dd}, J=10.8,3.5 \mathrm{~Hz}, 1 \mathrm{H}), 3.98(\mathrm{~d}, J=13.0 \mathrm{~Hz}, 1 \mathrm{H}), 4.28(\mathrm{~s}, 2 \mathrm{H}), 4.94$ (s, 2H), $6.64(\mathrm{dt}, J=7.6,1.2 \mathrm{~Hz}, 1 \mathrm{H}), 6.73(\mathrm{dd}, J=2.5,1.7 \mathrm{~Hz}, 1 \mathrm{H}), 6.92(\mathrm{ddd}, J=8.3,2.6,1.0$ $\mathrm{Hz}, 1 \mathrm{H}), 7.15(\mathrm{dd}, J=8.3,7.6 \mathrm{~Hz}, 1 \mathrm{H}), 7.29-7.37$ (m, 4H), 7.43-7.48 (m, 2H), 7.58-7.63 (m, 1H), 7.63-7.66 (m, 2H). ${ }^{13} \mathrm{C}$ NMR (101 MHz, $\left.\mathrm{CDCl}_{3}\right) \delta 23.5\left(\mathrm{CH}_{2}\right), 27.8\left(\mathrm{CH}_{2}\right), 54.5\left(\mathrm{CH}_{2}\right), 58.3\left(\mathrm{CH}_{2}\right)$, $61.8\left(\mathrm{CH}_{2}\right), 62.9\left(\mathrm{CH}_{2}\right), 64.4(\mathrm{CH}), 69.9\left(\mathrm{CH}_{2}\right), 115.7(\mathrm{CH}), 117.0(\mathrm{CH}), 123.4(\mathrm{CH}), 127.6$ $(2 \times \mathrm{CH}), 128.7(2 \times \mathrm{CH}), 128.9(2 \times \mathrm{CH}), 128.9(2 \times \mathrm{CH}), 129.5(\mathrm{C}), 129.6(\mathrm{CH}), 133.7(\mathrm{CH}), 135.5$ (C), 138.0 (C), 139.3 (C), 158.8 (C). ESI-HRMS [M + H] calcd for $\mathrm{C}_{26} \mathrm{H}_{30} \mathrm{NO}_{4} \mathrm{~S}^{+}, 452.1890$; found, 452.1904. HPLC: Method (A) $t_{R} 3.89 \min (99.5 \%)$.

\section{(R)-3-((4-((2-(Hydroxymethyl)pyrrolidin-1-yl)methyl)benzyl)oxy)phenyl}

benzenesulfonate (19). Following the procedure for 18, aldehyde $17(100 \mathrm{mg}, 0.271 \mathrm{mmol})$ afforded 19 (40 mg, 33\%) as a colourless oil. ${ }^{1} \mathrm{H}$ NMR (400 MHz, DMSO- $\left.d_{6}\right) \delta 1.52-1.65(\mathrm{~m}$, $3 \mathrm{H}), 1.79-1.88(\mathrm{~m}, 1 \mathrm{H}), 2.10-2.16(\mathrm{~m}, 1 \mathrm{H}), 2.52-2.59(\mathrm{~m}, 1 \mathrm{H}), 2.73-2.78(\mathrm{~m}, 1 \mathrm{H}), 3.26-3.31(\mathrm{br}$ m, $1 \mathrm{H}), 3.33$ (d, $J=13.3 \mathrm{~Hz}, 1 \mathrm{H}), 3.45$ (br. dd, $J=10.3$ and $3.9 \mathrm{~Hz}, 1 \mathrm{H}), 4.04(\mathrm{~d}, J=13.3 \mathrm{~Hz}$, 1H), $4.38(\mathrm{br} \mathrm{s}, 1 \mathrm{H}), 4.98(\mathrm{~s}, 2 \mathrm{H}), 6.59(\mathrm{ddd}, J=8.2,2.2$ and $0.7 \mathrm{~Hz}, 1 \mathrm{H}), 6.66(\mathrm{t}, J=2.3 \mathrm{~Hz}, 1 \mathrm{H})$, 6.96 (ddd, $J=8.4,2.4$ and $0.7 \mathrm{~Hz}, 1 \mathrm{H}), 7.27$ (t, $J=8.3 \mathrm{~Hz}, 1 \mathrm{H}$ ), 7.31 (app. s, 4H), 7.64-7.69 (m, 2H), 7.80-7.84 (m, 1H), 7.84-7.87 (m, 2H). ${ }^{13} \mathrm{C}$ NMR (101 MHz, DMSO- $\left.d_{6}\right) \delta 22.5,28.0,54.0$, $58.4,64.2,64.8,69.5,108.8,114.0,127.6,128.2,128.6,129.7,130.4,134.3,134.6,135.0,139.9$, 148.8, 149.8, 159.2. ESI-HRMS $[\mathrm{M}+\mathrm{H}]^{+}$calcd for $\mathrm{C}_{25} \mathrm{H}_{28} \mathrm{NO}_{5} \mathrm{~S}^{+}$, 454.1683; found, 454.1681. HPLC: Method (B) $t_{R} 6.64 \min (96.7 \%)$. 
3-(Phenylethynyl)phenol (20). A flask was charged under Ar with 3-iodophenol (1.51 g, $6.86 \mathrm{mmol})$, copper(I) iodide (140 mg, $734 \mu \mathrm{mol})$, tetrakis(triphenylphosphine)palladium(0) (382 $\mathrm{mg}, 332 \mu \mathrm{mol})$, anhydrous THF ( $30 \mathrm{~mL})$, triethylamine $(24 \mathrm{~mL})$ and phenylacetylene $(2.80 \mathrm{~g}, 27.4$ mmol). The mixture was stirred at ambient temperature for $48 \mathrm{~h}$, concentrated in vacuo and the resulting residue partitioned between $\mathrm{CHCl}_{3}(100 \mathrm{~mL})$ and $1 \mathrm{M} \mathrm{HCl}(\mathrm{aq})(200 \mathrm{~mL})$. The organic phase was dried $\left(\mathrm{MgSO}_{4}\right)$ and evaporated. The residual oil was processed by flash column chromatography $\left(1: 2: 8 \mathrm{Et}_{2} \mathrm{O} / \mathrm{CH}_{2} \mathrm{Cl}_{2} /\right.$ light petroleum $)$ followed by crystallisation $\left(\mathrm{CH}_{2} \mathrm{Cl}_{2} /\right.$ light petroleum) to afford $20(759 \mathrm{mg}, 57 \%)$ as off-white plates. ${ }^{1} \mathrm{H}$ NMR (400 $\left.\mathrm{MHz}, \mathrm{CDCl}_{3}\right) \delta 4.77$ (br. s, 1H), $6.83(\mathrm{ddd}, J=8.1,2.6$ and $1.0 \mathrm{~Hz}, 1 \mathrm{H}), 7.01(\mathrm{dd}, J=2.4$ and $1.4 \mathrm{~Hz}, 1 \mathrm{H}), 7.13(\mathrm{dt}, J=$ 7.6 and $1.2 \mathrm{~Hz}, 1 \mathrm{H}), 7.23(\mathrm{t}, J=7.9 \mathrm{~Hz}, 1 \mathrm{H}), 7.31-7.38(\mathrm{~m}, 3 \mathrm{H}), 7.50-7.55(\mathrm{~m}, 2 \mathrm{H}) .{ }^{13} \mathrm{C}$ NMR $\left(101 \mathrm{MHz}, \mathrm{CDCl}_{3}\right) \delta 89.1(\mathrm{C}), 89.6(\mathrm{C}), 115.9(\mathrm{CH}), 118.4(\mathrm{CH}), 123.3(\mathrm{C}), 124.6(\mathrm{CH}), 124.7$ (C), $128.5(3 \times \mathrm{CH}), 129.8(\mathrm{CH}), 131.8(2 \times \mathrm{CH}), 155.4(\mathrm{C})$.

3-Phenethylphenol (21). A solution of 20 (400 mg, $2.06 \mathrm{mmol})$ in $\mathrm{EtOH}(40 \mathrm{~mL})$ was hydrogenated using an $\mathrm{H}-\mathrm{Cube}^{\mathrm{TM}}$ (ThalesNano) fitted with a $10 \% \mathrm{Pd} / \mathrm{C}$ cartridge under full $\mathrm{H}_{2}$ mode at $30{ }^{\circ} \mathrm{C}$ with a flow rate of $0.7 \mathrm{~mL} /$ minute. The hydrogenated product solution was evaporated to 21 (390 $\mathrm{mg}, 95 \%$ ) as a colourless oil that solidified to a crystalline solid on standing. ${ }^{1} \mathrm{H}$ NMR (400 MHz, $\mathrm{CDCl}_{3}$ ) $\delta 2.86-2.95$ (m, 4H), 4.68 (br. s, 1H), 6.67-6.69 (m, 2H), 6.78 (app. $\mathrm{d}, J=7.5 \mathrm{~Hz}, 1 \mathrm{H}), 7.14-7.23(\mathrm{~m}, 4 \mathrm{H}), 7.27-7.32(\mathrm{~m}, 2 \mathrm{H}) .{ }^{13} \mathrm{C} \mathrm{NMR}\left(101 \mathrm{MHz}, \mathrm{CDCl}_{3}\right) \delta 37.75$ $\left(\mathrm{CH}_{2}\right), 37.80\left(\mathrm{CH}_{2}\right), 113.0(\mathrm{CH}), 115.6(\mathrm{CH}), 121.2(\mathrm{CH}), 126.1(\mathrm{CH}), 128.5(2 \times \mathrm{CH}), 128.6$ $(2 \times \mathrm{CH}), 129.7(\mathrm{CH}), 141.8(\mathrm{C}), 143.9(\mathrm{C}), 155.5(\mathrm{C})$.

4-((3-Phenethylphenoxy)methyl)benzaldehyde (22). A mixture of 4(bromomethyl)benzaldehyde (301 mg, $1.51 \mathrm{mmol}), 21(337 \mathrm{mg}, 1.70 \mathrm{mmol})$ and $\mathrm{K}_{2} \mathrm{CO}_{3}(707 \mathrm{mg}$, $5.12 \mathrm{mmol})$ in $\mathrm{MeCN}(10 \mathrm{~mL})$ was stirred at ambient temperature for $16 \mathrm{~h}$. The mixture was diluted 
with $\mathrm{CH}_{2} \mathrm{Cl}_{2}(25 \mathrm{~mL})$, filtered through Celite ${ }^{\circledR}$ and the filtrate evaporated to dryness. The residual oil was processed chromatographically $\left(20 \mathrm{~g} \mathrm{Strata}{ }^{\circledR} \mathrm{SI}-1\right.$ cartridge; $1: 39: 60 \mathrm{Et}_{2} \mathrm{O} / \mathrm{CH}_{2} \mathrm{Cl}_{2} /$ light petroleum) to afford $22(417 \mathrm{mg}, 87 \%)$ as a colourless oil. ${ }^{1} \mathrm{H}$ NMR $\left(400 \mathrm{MHz}, \mathrm{CDCl}_{3}\right) \delta 2.86-$ $2.96(\mathrm{~m}, 4 \mathrm{H}), 5.12$ (s, 2H), 6.79-6.84 (m, 3H), 7.16-7.23 (m, 4H), 7.26-7.31 (m, 2H), 7.59-7.62 (AA'BB' m, 2H), 7.89-7.92 (AA'BB' m, 2H), 10.03 (s, 1H). ${ }^{13} \mathrm{C}$ NMR (101 MHz, $\left.\mathrm{CDCl}_{3}\right) \delta 37.8$ $\left(\mathrm{CH}_{2}\right), 38.0\left(\mathrm{CH}_{2}\right), 69.2\left(\mathrm{CH}_{2}\right), 112.2(\mathrm{CH}), 115.3(\mathrm{CH}), 121.7(\mathrm{CH}), 126.1(\mathrm{CH}), 127.6(2 \times \mathrm{CH})$, $128.45(2 \times \mathrm{CH}), 128.55(2 \times \mathrm{CH}), 129.5(\mathrm{CH}), 130.1(2 \times \mathrm{CH}), 136.0(\mathrm{C}), 141.7(\mathrm{C}), 143.7(\mathrm{C}), 144.3$ (C), $158.5(\mathrm{C}), 192.0(\mathrm{CH})$.

\section{(R)-(1-(4-((3-Phenethylphenoxy)methyl)benzyl)pyrrolidin-2-yl)methanol}

(23).

Following the procedure for $\mathbf{1 8}$, aldehyde $\mathbf{2 2}(417 \mathrm{mg}, 1.32 \mathrm{mmol})$ afforded $\mathbf{2 3}(432 \mathrm{mg}, 82 \%)$ as a colourless oil. ${ }^{1} \mathrm{H}$ NMR $\left(400 \mathrm{MHz}, \mathrm{CDCl}_{3}\right) \delta 1.66-1.76(\mathrm{~m}, 2 \mathrm{H}), 1.81-2.00(\mathrm{~m}, 2 \mathrm{H}), 2.30(\mathrm{td}, J$ $=9.3$ and $7.5 \mathrm{~Hz}, 1 \mathrm{H}), 2.50-3.00($ br. $\mathrm{s}, 1 \mathrm{H}), 2.73-2.78(\mathrm{~m}, 1 \mathrm{H}), 2.88-2.96(\mathrm{~m}, 4 \mathrm{H}), 2.97-3.02(\mathrm{~m}$, 1H), $3.39(\mathrm{~d}, J=13.1 \mathrm{~Hz}, 1 \mathrm{H}), 3.45(\mathrm{dd}, J=10.8$ and $1.9 \mathrm{~Hz}, 1 \mathrm{H}), 3.68(\mathrm{dd}, J=10.8$ and $3.5 \mathrm{~Hz}$, 1H), $3.99(\mathrm{~d}, J=13.1 \mathrm{~Hz}, 1 \mathrm{H}), 5.02(\mathrm{~s}, 2 \mathrm{H}), 6.80-6.84(\mathrm{~m}, 3 \mathrm{H}), 7.19-7.23(\mathrm{~m}, 4 \mathrm{H}), 7.28-7.41(\mathrm{~m}$, 6H). ${ }^{13} \mathrm{C}$ NMR $\left(101 \mathrm{MHz}, \mathrm{CDCl}_{3}\right) \delta 23.6\left(\mathrm{CH}_{2}\right), 27.9\left(\mathrm{CH}_{2}\right), 37.9\left(\mathrm{CH}_{2}\right), 38.1\left(\mathrm{CH}_{2}\right), 54.5\left(\mathrm{CH}_{2}\right)$, $58.3\left(\mathrm{CH}_{2}\right), 61.9\left(\mathrm{CH}_{2}\right), 64.4(\mathrm{CH}), 69.8\left(\mathrm{CH}_{2}\right), 112.3(\mathrm{CH}), 115.3(\mathrm{CH}), 121.2(\mathrm{CH}), 126.0(\mathrm{CH})$, $127.7(2 \times \mathrm{CH}), 128.4(2 \times \mathrm{CH}), 128.5(2 \times \mathrm{CH}), 129.0(2 \times \mathrm{CH}), 129.4(\mathrm{CH}), 136.0(\mathrm{C}), 139.2(\mathrm{C})$, 141.8 (C), 143.5 (C), 159.0 (C). ESI-HRMS $[\mathrm{M}+\mathrm{H}]^{+}$calcd for $\mathrm{C}_{27} \mathrm{H}_{32} \mathrm{NO}_{2}{ }^{+}, 402.2428$; found, 402.2434. HPLC: Method (A) $t_{R} 4.73 \min (>99 \%)$.

3-(Benzyloxy)phenol (25). A heavy-walled sealable reaction flask was charged with resorcinol (2.20 g, $20.0 \mathrm{mmol}), \mathrm{K}_{2} \mathrm{CO}_{3}(2.80 \mathrm{~g}, 20.3 \mathrm{mmol})$, acetone $(30 \mathrm{~mL})$ and a magnetic stir bar. Benzyl bromide (1.72 g, $10.1 \mathrm{mmol})$ was added and the flask closed under Argon. The mixture was then heated at $65-70{ }^{\circ} \mathrm{C}$. After $5 \mathrm{~h}$ the mixture was returned to ambient temperature and 
filtered through Celite ${ }^{\circledR}$, washing well with acetone. The filtrate was evaporated to afford a residue that was partitioned between $\mathrm{CHCl}_{3}(100 \mathrm{~mL})$ and water $(100 \mathrm{~mL})$. The organic phase was separated and the aqueous layer extracted with $\mathrm{CHCl}_{3}(25 \mathrm{~mL})$. The combined organic phase was dried $\left(\mathrm{MgSO}_{4}\right)$ and evaporated to give a residue that was processed by flash column chromatography $\left(25 \% \mathrm{Et}_{2} \mathrm{O} /\right.$ light petroleum). Fractions containing the target material were evaporated to afford $25(1.11 \mathrm{~g}, 55 \%)$ as a colourless oil that solidified to a crystalline solid on standing. ${ }^{1} \mathrm{H}$ NMR (400 MHz, $\left.\mathrm{CDCl}_{3}\right) \delta 4.67$ (br s, 1H), 5.04 (s, 2H), 6.44 (ddd, $J=8.0,2.4$ and $0.9,1 \mathrm{H}), 6.49(\mathrm{t}, J=2.3,1 \mathrm{H}), 6.58(\mathrm{ddd}, J=8.3,2.4$ and $0.8,1 \mathrm{H}), 7.14(\mathrm{t}, J=8.1,1 \mathrm{H}), 7.30-7.45$ (m, 5H). ${ }^{13} \mathrm{C}$ NMR $\left(101 \mathrm{MHz}, \mathrm{CDCl}_{3}\right) \delta 70.2\left(\mathrm{CH}_{2}\right), 102.6(\mathrm{CH}), 107.6(\mathrm{CH}), 108.3(\mathrm{CH}), 127.6$ $(2 \times \mathrm{CH}), 128.1(\mathrm{CH}), 128.7(2 \times \mathrm{CH}), 130.3(\mathrm{CH}), 136.9(\mathrm{C}), 156.7(\mathrm{C}), 160.1(\mathrm{C})$.

3-((2-Fluorobenzyl)oxy)phenol (26). Following the procedure for 25, 2-fluorobenzyl bromide (1.91 g, $10.1 \mathrm{mmol})$ afforded $26(1.17 \mathrm{~g}, 53 \%)$ as a pale yellow oil. ${ }^{1} \mathrm{H}$ NMR (300 MHz, $\left.\mathrm{CDCl}_{3}\right) \delta 4.86(\mathrm{br} \mathrm{s}, 1 \mathrm{H}), 5.11(\mathrm{~s}, 2 \mathrm{H}), 6.45(\mathrm{ddd}, J=8.0,2.4$ and $0.8 \mathrm{~Hz}, 1 \mathrm{H}), 6.50(\mathrm{t}, J=2.3 \mathrm{~Hz}$, $1 \mathrm{H}), 6.59(\mathrm{ddd}, J=8.3,2.4$ and $0.8 \mathrm{~Hz}, 1 \mathrm{H}), 7.06-7.19(\mathrm{~m}, 3 \mathrm{H}), 7.32(\mathrm{tdd}, J=7.8,5.6$ and $2.1 \mathrm{~Hz}$, 1H), 7.47-7.53 (m, 1H). ${ }^{13} \mathrm{C} \mathrm{NMR}\left(75 \mathrm{MHz}, \mathrm{CDCl}_{3}\right) \delta 63.9\left(\mathrm{~d}, J=4.5 \mathrm{~Hz}, \mathrm{CH}_{2}\right), 102.6(\mathrm{CH})$, $107.5(\mathrm{CH}), 108.5(\mathrm{CH}), 115.4$ (d, $J=21.1 \mathrm{~Hz}, \mathrm{CH}), 124.0$ (d, $J=14.3 \mathrm{~Hz}, \mathrm{C}), 124.4$ (d, $J=3.6$ Hz, CH), 129.8 (d, J=2.9 Hz, CH), 129.9 (d, J=1.3 Hz, CH), 130.4 (CH), 156.6 (C), 159.9 (C), $160.6(\mathrm{~d}, J=247.1 \mathrm{~Hz}, \mathrm{C}) .{ }^{19} \mathrm{~F}$ NMR $\left(282 \mathrm{MHz}, \mathrm{CDCl}_{3}\right) \delta-118.5$.

3-((3-Fluorobenzyl)oxy)phenol (27). Following the procedure for 25, 3-fluorobenzyl bromide (1.91 g, $10.1 \mathrm{mmol})$ afforded $27(1.27 \mathrm{~g}, 58 \%)$ as a pale yellow oil. ${ }^{1} \mathrm{H}$ NMR (300 MHz, $\left.\mathrm{CDCl}_{3}\right) \delta 5.03(\mathrm{~s}, 2 \mathrm{H}), 5.07(\mathrm{br} \mathrm{s}, 1 \mathrm{H}), 6.44-6.49(\mathrm{~m}, 2 \mathrm{H}), 6.57(\mathrm{ddd}, J=8.3,2.3$ and $0.9 \mathrm{~Hz}, 1 \mathrm{H})$, 6.98-7.05 (m, 1H), 7.12-7.20 (m, 3H), $7.34(\mathrm{td}, J=7.9$ and $5.8 \mathrm{~Hz}, 1 \mathrm{H}) .{ }^{13} \mathrm{C}$ NMR $(75 \mathrm{MHz}$, $\left.\mathrm{CDCl}_{3}\right) \delta 69.3\left(\mathrm{CH}_{2}\right), 102.6(\mathrm{CH}), 107.6(\mathrm{CH}), 108.5(\mathrm{CH}), 114.3(\mathrm{~d}, J=22.0 \mathrm{~Hz}, \mathrm{CH}), 114.9(\mathrm{~d}$, 
$J=21.1 \mathrm{~Hz}, \mathrm{CH}), 122.9(\mathrm{CH}), 130.2(\mathrm{~d}, J=8.2 \mathrm{~Hz}, \mathrm{CH}), 130.4(\mathrm{CH}), 139.5$ (d, $J=7.3 \mathrm{~Hz}, \mathrm{C})$, 159.8 (C), $161.4(\mathrm{C}), 163.1(\mathrm{~d}, J=246.1 \mathrm{~Hz}, \mathrm{C}) .{ }^{19} \mathrm{~F} \mathrm{NMR}\left(282 \mathrm{MHz}, \mathrm{CDCl}_{3}\right) \delta-112.6$.

3-((4-Fluorobenzyl)oxy)phenol (28). Following the procedure for 25, 4-fluorobenzyl bromide (1.83 g, $9.67 \mathrm{mmol})$ afforded $\mathbf{2 8}(803 \mathrm{mg}, 38 \%)$ as a colourless crystalline solid. ${ }^{1} \mathrm{H}$ NMR $\left(400 \mathrm{MHz}, \mathrm{CDCl}_{3}\right) \delta 4.98($ br s, $1 \mathrm{H}), 4.99(\mathrm{~s}, 2 \mathrm{H}), 6.45(\mathrm{ddd}, J=7.9,2.3$ and $0.8,1 \mathrm{H}), 6.48(\mathrm{t}, J=$ 2.2, 1H), $6.56(\mathrm{ddd}, J=8.3,2.3$ and $0.9,1 \mathrm{H}), 7.03-7.11(\mathrm{~m}, 2 \mathrm{H}), 7.14(\mathrm{t}, J=8.1,1 \mathrm{H}), 7.36-7.43$ (m, 2H). ${ }^{13} \mathrm{C}$ NMR $\left(75 \mathrm{MHz}, \mathrm{CDCl}_{3}\right) \delta 69.5\left(\mathrm{CH}_{2}\right), 102.7(\mathrm{CH}), 107.4(\mathrm{CH}), 108.4(\mathrm{CH}), 115.6$ (d, $J=21.4, \mathrm{CH}), 129.5(\mathrm{~d}, J=8.2, \mathrm{CH}), 130.3(\mathrm{CH}), 132.7$ (d, $J=3.0, \mathrm{C}), 156.9(\mathrm{C}), 160.0(\mathrm{C})$, $162.6(\mathrm{~d}, J=246, \mathrm{C}) .{ }^{19} \mathrm{~F}$ NMR $\left(282 \mathrm{MHz}, \mathrm{CDCl}_{3}\right) \delta-114.2$.

3-((2-Chlorobenzyl)oxy)phenol (29). Following the procedure for 25, 2-chlorobenzyl bromide (2.01 g, $9.79 \mathrm{mmol})$ afforded $29(1.24 \mathrm{~g}, 54 \%)$ as a pale yellow oil. ${ }^{1} \mathrm{H}$ NMR (300 MHz, $\left.\mathrm{CDCl}_{3}\right) \delta 4.72(\mathrm{br} \mathrm{s}, 1 \mathrm{H}), 5.11(\mathrm{~s}, 2 \mathrm{H}), 6.42(\mathrm{dd}, J=8.0$ and $2.3 \mathrm{~Hz}, 1 \mathrm{H}), 6.47(\mathrm{t}, J=2.3 \mathrm{~Hz}, 1 \mathrm{H})$, $6.55(\mathrm{dd}, J=8.2$ and $2.3 \mathrm{~Hz}, 1 \mathrm{H}), 7.12(\mathrm{t}, J=8.1,1 \mathrm{H}), 7.19-7.29(\mathrm{~m}, 2 \mathrm{H}), 7.32-7.39(\mathrm{~m}, 1 \mathrm{H})$, 7.48-7.54 (m, 1H). ${ }^{13} \mathrm{C}$ NMR (75 MHz, $\left.\mathrm{CDCl}_{3}\right) \delta 67.3\left(\mathrm{CH}_{2}\right), 102.7(\mathrm{CH}), 107.5(\mathrm{CH}), 108.6$ $(\mathrm{CH}), 127.0(\mathrm{CH}), 129.0(\mathrm{CH}), 129.1(\mathrm{CH}), 129.4(\mathrm{CH}), 130.4(\mathrm{CH}), 132.7(\mathrm{C}), 134.5(\mathrm{C}), 156.7$ (C), $159.8(\mathrm{C})$.

3-((3-Chlorobenzyl)oxy)phenol (30). Following the procedure for 25, 3-chlorobenzyl bromide (2.01 g, $9.77 \mathrm{mmol})$ afforded $30(1.12 \mathrm{~g}, 49 \%)$ as a pale yellow oil. ${ }^{1} \mathrm{H}$ NMR (300 MHz, $\left.\mathrm{CDCl}_{3}\right) \delta 4.90(\mathrm{br} \mathrm{s}, 1 \mathrm{H}), 5.01(\mathrm{~s}, 2 \mathrm{H}), 6.44-6.48(\mathrm{~m}, 2 \mathrm{H}), 6.55(\mathrm{ddd}, J=8.3,2.2$ and $1.1 \mathrm{~Hz}, 1 \mathrm{H})$, 7.11-7.18 (m, 1H), 7.28-7.40 (m, 3H), 7.32-7.39 (m, 1H), 7.42-7.44 (m, 1H). ${ }^{13} \mathrm{C}$ NMR (75 MHz, $\left.\mathrm{CDCl}_{3}\right) \delta 69.3\left(\mathrm{CH}_{2}\right), 102.6(\mathrm{CH}), 107.5(\mathrm{CH}), 108.6(\mathrm{CH}), 125.5(\mathrm{CH}), 127.5(\mathrm{CH}), 128.2(\mathrm{CH})$, $129.9(\mathrm{CH}), 130.4(\mathrm{CH}), 134.5(\mathrm{C}), 138.9(\mathrm{C}), 156.6(\mathrm{C}), 159.8(\mathrm{C})$. 
3-((4-Chlorobenzyl)oxy)phenol (31). Following the procedure for 25, 4-chlorobenzyl chloride (1.62 g, $10.1 \mathrm{mmol})$ afforded $31(1.14 \mathrm{~g}, 48 \%)$ as a colourless crystalline solid. ${ }^{1} \mathrm{H}$ NMR $\left(400 \mathrm{MHz}, \mathrm{CDCl}_{3}\right) \delta 4.99(\mathrm{~s}, 2 \mathrm{H}), 5.12(\mathrm{br} \mathrm{s}, 1 \mathrm{H}), 6.43-6.48(\mathrm{~m}, 2 \mathrm{H}), 6.56(\mathrm{dd}, J=8.1$ and 2.2, 1H), $7.14(\mathrm{t}, J=8.1,1 \mathrm{H}), 7.30-7.40$ (tight AA'BB' m, 4H). ${ }^{13} \mathrm{C}$ NMR (101 MHz, $\left.\mathrm{CDCl}_{3}\right) \delta 69.5$ $\left(\mathrm{CH}_{2}\right), 102.8(\mathrm{CH}), 107.6(\mathrm{CH}), 108.5(\mathrm{CH}), 128.9(4 \times \mathrm{CH}), 130.4(\mathrm{CH}), 133.9(\mathrm{C}), 135.5(\mathrm{C})$, $156.8(\mathrm{C}), 160.1(\mathrm{C})$.

3-((4-Methoxybenzyl)oxy)phenol (32). Following the procedure for 25, 4-methoxybenzyl chloride (1.57 g, $10.0 \mathrm{mmol})$ afforded $32(736 \mathrm{mg}, 32 \%)$ as a white powder. ${ }^{1} \mathrm{H}$ NMR $(300 \mathrm{MHz}$, $\left.\mathrm{CDCl}_{3}\right) \delta 3.82(\mathrm{~s}, 3 \mathrm{H}), 4.67(\mathrm{br} \mathrm{s}, 1 \mathrm{H}), 4.96(\mathrm{~s}, 2 \mathrm{H}), 6.43(1 \mathrm{H}, \mathrm{ddd}, J=8.0,2.4$ and $0.8,1 \mathrm{H}), 6.47$ $(\mathrm{t}, J=2.3,1 \mathrm{H}), 6.57(\mathrm{ddd}, J=8.3,2.4$ and $0.8,1 \mathrm{H}), 6.89-6.94\left(\mathrm{AA}^{\prime} \mathrm{BB}^{\prime} \mathrm{m}, 2 \mathrm{H}\right), 7.13(\mathrm{t}, J=8.2$, 1H), 7.33-7.37 (AA'BB' m, 2H). ${ }^{13} \mathrm{C}$ NMR (75 MHz, $\left.\mathrm{CDCl}_{3}\right) \delta 55.5\left(\mathrm{CH}_{3}\right), 70.0\left(\mathrm{CH}_{2}\right), 102.6$ $(\mathrm{CH}), 107.5(\mathrm{CH}), 108.1(\mathrm{CH}), 114.2(2 \times \mathrm{CH}), 129.1(\mathrm{C}), 129.4(2 \times \mathrm{CH}), 130.3(\mathrm{CH}), 156.8(\mathrm{C})$, $159.4(\mathrm{C}), 160.3(\mathrm{C})$.

4-((3-Hydroxyphenoxy)methyl)benzonitrile (33). Following the procedure for 25 , 4cyanobenzyl bromide (1.96 g, $9.98 \mathrm{mmol})$ afforded $33(1.05 \mathrm{~g}, 47 \%)$ as an off-white powder. ${ }^{1} \mathrm{H}$ $\operatorname{NMR}\left(400 \mathrm{MHz}, \mathrm{CDCl}_{3}\right) \delta 4.90(\mathrm{br} \mathrm{s}, 1 \mathrm{H}), 5.10(\mathrm{~s}, 2 \mathrm{H}), 6.45-6.48(\mathrm{~m}, 2 \mathrm{H}), 6.53$ (ddd, $J=8.3$, 2.3 and 1.0, 1H), 7.12-7.17 (m, 1H), 7.52-7.55 (AA'BB' m, 2H), 7.66-7.69 (AA'BB' m, 2H). ${ }^{13} \mathrm{C}$ $\operatorname{NMR}\left(101 \mathrm{MHz}, \mathrm{CDCl}_{3}\right) \delta 69.1\left(\mathrm{CH}_{2}\right), 102.7(\mathrm{CH}), 107.4(\mathrm{CH}), 108.8(\mathrm{CH}), 111.9(\mathrm{C}), 118.8(\mathrm{C})$, $127.7(2 \times \mathrm{CH}), 130.5(\mathrm{CH}), 132.6(2 \times \mathrm{CH}), 142.7(\mathrm{C}), 157.1(\mathrm{C}), 159.8(\mathrm{C})$.

3-(Benzylthio)phenol (34). A mixture of 3-mercaptophenol (621 mg, $4.92 \mathrm{mmol})$, benzyl bromide $(888 \mathrm{mg}, 5.19 \mathrm{mmol})$ and $\mathrm{K}_{2} \mathrm{CO}_{3}(2.05 \mathrm{~g}, 14.8 \mathrm{mmol})$ in acetonitrile $(10 \mathrm{~mL})$ was stirred under $\mathrm{Ar}$ at ambient temperature. After $2 \mathrm{~d}$ the reaction mixture was diluted with $\mathrm{CH}_{2} \mathrm{Cl}_{2}(25 \mathrm{~mL})$ and filtered through Celite ${ }^{\circledR}$, washing well with $\mathrm{CH}_{2} \mathrm{Cl}_{2}$. The filtrate was evaporated and the 
residue processed chromatographically $\left(20\right.$ g Strata ${ }^{\circledR}$ SI-1 cartridge; 1:3:8 $\mathrm{Et}_{2} \mathrm{O} / \mathrm{CH}_{2} \mathrm{Cl}_{2} /$ light petroleum) to afford $34(720 \mathrm{mg}, 68 \%)$ as a colourless solid. ${ }^{1} \mathrm{H}$ NMR (400 MHz, $\left.\mathrm{CDCl}_{3}\right) \delta 4.12$ (s, 2H), 4.90 (br. s, 1H), 6.64 (ddd, $J=8.1,2.5$ and $0.9 \mathrm{~Hz}, 1 \mathrm{H}), 6.78$ (t, $J=2.1 \mathrm{~Hz}, 1 \mathrm{H}), 6.88$ (ddd, $J=7.8,1.7$ and $0.9 \mathrm{~Hz}, 1 \mathrm{H}), 7.13(\mathrm{t}, J=7.9 \mathrm{~Hz}, 1 \mathrm{H}), 7.22-7.33(\mathrm{~m}, 5 \mathrm{H}) .{ }^{13} \mathrm{C}$ NMR $(101$ $\left.\mathrm{MHz}, \mathrm{CDCl}_{3}\right) \delta 38.6\left(\mathrm{CH}_{2}\right), 113.5(\mathrm{CH}), 116.1(\mathrm{CH}), 121.7(\mathrm{CH}), 127.4(\mathrm{CH}), 128.6(2 \times \mathrm{CH})$, $128.9(2 \times \mathrm{CH}), 130.0(\mathrm{CH}), 137.2(\mathrm{C}), 138.1(\mathrm{C}), 155.8(\mathrm{C})$

3-((4-Fluorobenzyl)thio)phenol (35). Following the procedure for 34, 3-mercaptophenol (500 $\mu \mathrm{L}, 4.91 \mathrm{mmol}$ ) was alkylated with 4-fluorobenzyl bromide (930 $\mathrm{mg}, 4.92 \mathrm{mmol}$ ) to afford $35(818 \mathrm{mg}, 71 \%)$ as a colourless solid. ${ }^{1} \mathrm{H}$ NMR $\left(400 \mathrm{MHz}, \mathrm{CDCl}_{3}\right) \delta 4.08(\mathrm{~s}, 2 \mathrm{H}), 4.68$ (br. s, 1H), 6.65 (ddd, $J 8.1,2.5$ and $0.9 \mathrm{~Hz}, 1 \mathrm{H}), 6.77$ (ddd, $J=2.5,1.7$ and $0.3 \mathrm{~Hz}, 1 \mathrm{H}$ ), 6.86 (ddd, $J=$ 7.8, 1.7 and $0.9 \mathrm{~Hz}, 1 \mathrm{H}), 6.94-7.00(\mathrm{~m}, 2 \mathrm{H}), 7.13(\mathrm{td}, J=7.9$ and $0.3 \mathrm{~Hz}, 1 \mathrm{H}), 7.23-7.28(\mathrm{~m}, 2 \mathrm{H})$. ${ }^{13} \mathrm{C}$ NMR $\left(101 \mathrm{MHz}, \mathrm{CDCl}_{3}\right) \delta 38.1\left(\mathrm{CH}_{2}\right), 113.7(\mathrm{CH}), 115.5(\mathrm{~d}, J=21.5 \mathrm{~Hz}, 2 \times \mathrm{CH}), 116.4(\mathrm{CH})$, $122.1(\mathrm{CH}), 130.1(\mathrm{CH}), 130.5(\mathrm{~d}, J=8.1 \mathrm{~Hz}, 2 \times \mathrm{CH}), 133.1(\mathrm{~d}, J=3.2 \mathrm{~Hz}, \mathrm{C}), 137.8(\mathrm{C}), 155.7$ (C), $162.1(\mathrm{~d}, J=245.7 \mathrm{~Hz}, \mathrm{C}) .{ }^{19} \mathrm{~F} \mathrm{NMR}\left(376 \mathrm{MHz}, \mathrm{CDCl}_{3}\right) \delta-115.3$.

3-((4-Chlorobenzyl)thio)phenol (36). Following the procedure for 34, 3-mercaptophenol (500 $\mu \mathrm{L}, 4.91 \mathrm{mmol})$ was alkylated with 4-chlorobenzyl chloride ( $823 \mathrm{mg}, 5.11 \mathrm{mmol})$ to afford $36(969 \mathrm{mg}, 79 \%)$ as a colourless solid. ${ }^{1} \mathrm{H}$ NMR (400 MHz, $\left.\mathrm{CDCl}_{3}\right) \delta 4.06$ (s, 2H), 4.72 (br. s, 1H), 6.65 (ddd, $J=8.1,2.5$ and $0.9 \mathrm{~Hz}, 1 \mathrm{H}), 6.76$ (app. t, $J=2.1 \mathrm{~Hz}, 1 \mathrm{H}), 6.86(\mathrm{ddd}, J=7.8,1.7$ and $0.9 \mathrm{~Hz}, 1 \mathrm{H}$ ), 7.13 (app. t, $J=7.9 \mathrm{~Hz}, 1 \mathrm{H}), 7.21-7.27$ (m, 4H). ${ }^{13} \mathrm{C} \mathrm{NMR}\left(101 \mathrm{MHz}, \mathrm{CDCl}_{3}\right) \delta$ $38.2\left(\mathrm{CH}_{2}\right), 113.8(\mathrm{CH}), 116.4(\mathrm{CH}), 122.2(\mathrm{CH}), 128.8(2 \times \mathrm{CH}), 130.1(\mathrm{CH}), 130.2(2 \times \mathrm{CH}), 133.1$ (C), $135.9(\mathrm{C}), 137.5(\mathrm{C}), 155.7(\mathrm{C})$.

4-((3-(Benzyloxy)phenoxy)methyl)benzaldehyde (37). To a solution of 25 (328 mg, 1.64 $\mathrm{mmol})$ in anhydrous DMF (6 mL) under argon was added $\mathrm{NaH}(60 \% \mathrm{w} / \mathrm{w}$ in mineral oil; $83.0 \mathrm{mg}$, 
$2.08 \mathrm{mmol}$ ). The mixture was sonicated for $2 \mathrm{~min}$ to aid dispersal of the hydride reagent and then stirred at ambient temperature for $15 \mathrm{~min}$ prior to addition of 4-(bromomethyl)benzaldehyde (365 $\mathrm{mg}, 1.83 \mathrm{mmol})$. After a further $16 \mathrm{~h}$ the mixture was evaporated to dryness $\left(65^{\circ} \mathrm{C} / 15 \mathrm{mbar}\right)$. The resulting residue was taken up in $\mathrm{CH}_{2} \mathrm{Cl}_{2}(20 \mathrm{~mL})$ and filtered through Celite ${ }^{\circledR}$, washing well with $\mathrm{CHCl}_{3}$. The filtrate was evaporated to dryness and pumped to remove residual DMF. Chromatographic processing of the residue $\left(20 \mathrm{~g} \mathrm{Strata}^{\circledR}\right.$ SI-1 cartridge; $1: 49.5: 49.5$ $\mathrm{Et}_{2} \mathrm{O} / \mathrm{CH}_{2} \mathrm{Cl}_{2} /$ light petroleum) afford 37 (461 mg, 88\%) as a colourless solid. ${ }^{1} \mathrm{H}$ NMR (300 MHz, $\left.\mathrm{CDCl}_{3}\right) \delta 5.06(\mathrm{~s}, 2 \mathrm{H}), 5.13(\mathrm{~s}, 2 \mathrm{H}), 6.59-6.66(\mathrm{~m}, 3 \mathrm{H}), 7.19-7.24(\mathrm{~m}, 1 \mathrm{H}), 7.31-7.46(\mathrm{~m}, 5 \mathrm{H})$, 7.57-7.62 (AA'BB' m, 2H), 7.89-7.92 (AA'BB' m, 2H), 10.03 (s, 1H). ${ }^{13} \mathrm{C}$ NMR (75 MHz, $\mathrm{CDCl}_{3}$ ) $\delta 69.0\left(\mathrm{CH}_{2}\right), 69.9\left(\mathrm{CH}_{2}\right), 102.2(\mathrm{CH}), 107.3(\mathrm{CH}), 107.5(\mathrm{CH}), 127.3(2 \times \mathrm{CH}), 127.4(2 \times \mathrm{CH})$, $127.9(\mathrm{CH}), 128.5(2 \times \mathrm{CH}), 129.8(2 \times \mathrm{CH}), 130.0(\mathrm{CH}), 135.8(\mathrm{C}), 136.8(\mathrm{C}), 143.8(\mathrm{C}), 159.5(\mathrm{C})$, $160.0(\mathrm{C}), 191.7(\mathrm{CH})$.

4-((3-((2-Fluorobenzyl)oxy)phenoxy)methyl)benzaldehyde (38). Following the procedure for 37, phenol 26 (333 $\mathrm{mg}, 1.53 \mathrm{mmol})$ was alkylated to give $\mathbf{3 8}(317 \mathrm{mg}, 62 \%)$ as a colourless solid. ${ }^{1} \mathrm{H}$ NMR $\left(300 \mathrm{MHz}, \mathrm{CDCl}_{3}\right) \delta 5.12(\mathrm{~s}, 2 \mathrm{H}), 5.14(\mathrm{~s}, 2 \mathrm{H}), 6.58-6.66(\mathrm{~m}, 3 \mathrm{H}), 7.08$ (ddd, $J=9.9,8.4$ and $1.3 \mathrm{~Hz}, 1 \mathrm{H}), 7.16(\mathrm{td}, J=7.5$ and 1.2, 1H), 7.18-7.24 (m, 1H), 7.28-7.36 (m, 1H), 7.47-7.52 (m, 1H), 7.57-7.61 (AA'BB' m, 2H), 7.88-7.92 (AA'BB' m, 2H), 10.03 (s, 1H). ${ }^{13} \mathrm{C} \mathrm{NMR}\left(75 \mathrm{MHz}, \mathrm{CDCl}_{3}\right) \delta 63.8\left(\mathrm{~d}, J=4.5 \mathrm{~Hz}, \mathrm{CH}_{2}\right), 69.3\left(\mathrm{CH}_{2}\right), 102.3(\mathrm{CH}), 107.6(\mathrm{CH})$, $107.7(\mathrm{CH}), 115.4(\mathrm{~d}, J=21.0 \mathrm{~Hz}, \mathrm{CH}), 124.1$ (d, $J=14.3 \mathrm{~Hz}, \mathrm{C}), 124.3(\mathrm{~d}, J=3.7 \mathrm{~Hz}, \mathrm{CH}), 127.5$ $(2 \times \mathrm{CH}), 129.77(\mathrm{CH}), 129.84(\mathrm{~d}, J=4.1, \mathrm{CH}), 130.1(2 \times \mathrm{CH}), 130.2(\mathrm{CH}), 136.0(\mathrm{C}), 144.0(\mathrm{C})$, 159.7 (C), 159.9 (C), 160.5 (d, $J=246.9 \mathrm{~Hz}, \mathrm{C}), 191.9(\mathrm{CH}) .{ }^{19} \mathrm{~F}$ NMR $\left(282 \mathrm{MHz}, \mathrm{CDCl}_{3}\right) \delta-$ 118.6 . 
4-((3-((3-Fluorobenzyl)oxy)phenoxy)methyl)benzaldehyde (39). Following the procedure for 37, phenol 27 (325 mg, $1.49 \mathrm{mmol}$ ) was alkylated to give 39 (322 mg, 64\%) as a colourless solid. ${ }^{1} \mathrm{H}$ NMR (400 MHz, $\left.\mathrm{CDCl}_{3}\right) \delta 5.04(\mathrm{~s}, 2 \mathrm{H}), 5.13(\mathrm{~s}, 2 \mathrm{H}), 6.59-6.62$ (m, 3H), 7.99-7.04 (m, 1H), 7.13-7.23 (m, 3H), $7.34(\mathrm{td}, J=7.9$ and $5.8 \mathrm{~Hz}, 1 \mathrm{H}), 7.57-7.61$ (AA'BB' m, 2H), 7.89-7.92 (AA'BB' m, 2H), $10.03(\mathrm{~s}, 1 \mathrm{H}) .{ }^{13} \mathrm{C}$ NMR (101 MHz, $\left.\mathrm{CDCl}_{3}\right) \delta 69.3(\mathrm{~d}, J=2.0$ $\left.\mathrm{Hz}, \mathrm{CH}_{2}\right), 69.4\left(\mathrm{CH}_{2}\right), 102.6(\mathrm{CH}), 107.7(\mathrm{CH}), 107.8(\mathrm{CH}), 114.3(\mathrm{~d}, J=22.1 \mathrm{~Hz}, \mathrm{CH}), 114.9$ (d, $J=21.2 \mathrm{~Hz}, \mathrm{CH}), 122.8(\mathrm{~d}, J=2.9 \mathrm{~Hz}, \mathrm{CH}), 127.5(2 \times \mathrm{CH}), 130.1(2 \times \mathrm{CH}), 130.20(\mathrm{~d}, J=8.1$, CH), 130.1 (CH), 136.1 (C), 139.7 (d, $J=7.3 \mathrm{~Hz}, \mathrm{C}), 144.0$ (C), 159.8 (C), 159.9 (C), 163.1 (d, $J$ $=246.2 \mathrm{~Hz}, \mathrm{C}), 191.8(\mathrm{CH}) .{ }^{19} \mathrm{~F}$ NMR $\left(376 \mathrm{MHz}, \mathrm{CDCl}_{3}\right) \delta-112.6$.

4-((3-((4-Fluorobenzyl)oxy)phenoxy)methyl)benzaldehyde (40). Following the procedure for 37, phenol 28 (325 mg, $1.49 \mathrm{mmol})$ was alkylated to give $\mathbf{4 0}(388 \mathrm{mg}, 77 \%)$ as a colourless solid. ${ }^{1} \mathrm{H}$ NMR $\left(300 \mathrm{MHz}, \mathrm{CDCl}_{3}\right) \delta 5.00(\mathrm{~s}, 2 \mathrm{H}), 5.13(\mathrm{~s}, 2 \mathrm{H}), 6.58-6.63(\mathrm{~m}, 3 \mathrm{H})$, 7.03-7.11 (m, 2H), 7.17-7.24 (m, 1H), 7.36-7.43 (m, 2H), 7.56-7.62 (AA'BB' m, 2H), 7.88-7.92 (AA'BB' m, 2H), $10.02(\mathrm{~s}, 1 \mathrm{H}) .{ }^{13} \mathrm{C}$ NMR $\left(75 \mathrm{MHz}, \mathrm{CDCl}_{3}\right) \delta 69.1\left(\mathrm{CH}_{2}\right), 69.2\left(\mathrm{CH}_{2}\right), 102.3(\mathrm{CH})$, 107.4 (CH), 107.6 (CH), $115.4(\mathrm{~d}, J=21.0 \mathrm{~Hz}, 2 \times \mathrm{CH}), 127.4(2 \times \mathrm{CH}), 129.3(\mathrm{~d}, J=7.7 \mathrm{~Hz}, 2 \times \mathrm{CH})$, $129.9(2 \times \mathrm{CH}), 130.1(\mathrm{CH}), 132.6(\mathrm{~d}, J=3.3 \mathrm{~Hz}, \mathrm{C}), 135.9(\mathrm{C}), 143.8(\mathrm{C}), 159.6(\mathrm{C}), 159.9(\mathrm{C})$, $162.4(\mathrm{~d}, J=247 \mathrm{~Hz}, \mathrm{C}), 191.7(\mathrm{CH}) .{ }^{19} \mathrm{~F} \mathrm{NMR}\left(282 \mathrm{MHz}, \mathrm{CDCl}_{3}\right) \delta-113.9$.

4-((3-((2-Chlorobenzyl)oxy)phenoxy)methyl)benzaldehyde (41). Following the procedure for 37, phenol 29 (352 mg, $1.50 \mathrm{mmol})$ was alkylated to give 41 (374 mg, 71\%) as a colourless solid. ${ }^{1} \mathrm{H}$ NMR $\left(300 \mathrm{MHz}, \mathrm{CDCl}_{3}\right) \delta 5.14(\mathrm{~s}, 2 \mathrm{H}), 5.15(\mathrm{~s}, 2 \mathrm{H}), 6.59-6.66(\mathrm{~m}, 3 \mathrm{H})$, 7.19-7.32 (m, 3H), 7.31-7.43 (m, 1H), 7.53-7.56 (m, 1H), 7.57-7.61 (AA'BB' m, 2H), 7.88-7.92 (AA'BB' m, 2H), $10.03(\mathrm{~s}, 1 \mathrm{H}) .{ }^{13} \mathrm{C} \mathrm{NMR}\left(75 \mathrm{MHz}, \mathrm{CDCl}_{3}\right) \delta 67.2\left(\mathrm{CH}_{2}\right), 69.3\left(\mathrm{CH}_{2}\right), 102.3(\mathrm{CH})$, 
$107.6(\mathrm{CH}), 107.8(\mathrm{CH}), 127.0(\mathrm{CH}), 127.5(2 \times \mathrm{CH}), 128.9(\mathrm{CH}), 129.1(\mathrm{CH}), 129.4(\mathrm{CH}), 130.1$ $(2 \times \mathrm{CH}), 130.2(\mathrm{CH}), 132.6(\mathrm{C}), 134.6(\mathrm{C}), 136.0(\mathrm{C}), 144.0(\mathrm{C}), 159.7(\mathrm{C}), 159.9(\mathrm{C}), 191.9(\mathrm{CH})$. 4-((3-((3-Chlorobenzyl)oxy)phenoxy)methyl)benzaldehyde (42). Following the procedure for 37, phenol 30 (348 $\mathrm{mg}, 1.48 \mathrm{mmol}$ ) was alkylated to give $\mathbf{4 2}$ (286 $\mathrm{mg}, 55 \%)$ as a colourless solid. ${ }^{1} \mathrm{H}$ NMR $\left(300 \mathrm{MHz}, \mathrm{CDCl}_{3}\right) \delta 5.02(\mathrm{~s}, 2 \mathrm{H}), 5.13(\mathrm{~s}, 2 \mathrm{H}), 6.58-6.62(\mathrm{~m}, 3 \mathrm{H})$, 7.17-7.23 (m, 1H), 7.27-7.34 (m, 3H), 7.41-7.44 (m, 1H), 7.57-7.61 (AA'BB' m, 2H), 7.88-7.92 (AA'BB' m, 2H), $10.03(\mathrm{~s}, 1 \mathrm{H}) .{ }^{13} \mathrm{C}$ NMR $\left(75 \mathrm{MHz}, \mathrm{CDCl}_{3}\right) \delta 69.1\left(\mathrm{CH}_{2}\right), 69.2\left(\mathrm{CH}_{2}\right), 102.3(\mathrm{CH})$, $107.6(2 \times \mathrm{CH}), 125.4(\mathrm{CH}), 127.39(\mathrm{CH}), 127.44(2 \times \mathrm{CH}), 128.1(\mathrm{CH}), 129.9(\mathrm{CH}), 130.0(2 \times \mathrm{CH})$, $130.2(\mathrm{CH}), 134.5(\mathrm{C}), 136.0(\mathrm{C}), 139.0(\mathrm{C}), 143.9(\mathrm{C}), 159.6(\mathrm{C}), 159.8(\mathrm{C}), 191.8(\mathrm{CH})$.

4-((3-((4-Chlorobenzyl)oxy)phenoxy)methyl)benzaldehyde (43). Following the procedure for 37, phenol 31 (331 $\mathrm{mg}, 1.41 \mathrm{mmol})$ was alkylated to give $\mathbf{4 3}(476 \mathrm{mg}, 96 \%)$ as a colourless solid. ${ }^{1} \mathrm{H}$ NMR $\left(300 \mathrm{MHz}, \mathrm{CDCl}_{3}\right) \delta 5.01(\mathrm{~s}, 2 \mathrm{H}), 5.13(\mathrm{~s}, 2 \mathrm{H}), 6.58-6.61(\mathrm{~m}, 3 \mathrm{H})$, 7.17-7.23 (m, 1H), 7.35 (app. s, 4H), 7.56-7.61 (AA'BB' m, 2H), 7.88-7.92 (AA'BB' m, 2H), $10.03(\mathrm{~s}, 1 \mathrm{H}) .{ }^{13} \mathrm{C} \mathrm{NMR}\left(75 \mathrm{MHz}, \mathrm{CDCl}_{3}\right) \delta 69.18\left(\mathrm{CH}_{2}\right), 69.20\left(\mathrm{CH}_{2}\right), 102.3(\mathrm{CH}), 107.5(\mathrm{CH})$, 107.6 $(\mathrm{CH}), 127.4(2 \times \mathrm{CH}), 128.74(2 \times \mathrm{CH}), 128.78(2 \times \mathrm{CH}), 130.0(2 \times \mathrm{CH}), 130.1(\mathrm{CH}), 133.7$ (C), 135.4 (C), 135.9 (C), 143.9 (C), 159.6 (C), 159.8 (C), $191.8(\mathrm{CH})$.

4-((3-((4-Methoxybenzyl)oxy)phenoxy)methyl)benzaldehyde (44). Following the procedure for 37, phenol $32(250 \mathrm{mg}, 1.09 \mathrm{mmol})$ was alkylated to give $44(256 \mathrm{mg}, 68 \%)$ as a colourless solid. ${ }^{1} \mathrm{H}$ NMR (300 MHz, $\left.\mathrm{CDCl}_{3}\right) \delta 3.82(\mathrm{~s}, 3 \mathrm{H}), 4.97$ (s, 2H), $5.13(\mathrm{~s}, 2 \mathrm{H}), 6.56-6.64$ (m, 3H), 6.89-6.94 (AA'BB' m, 2H), 7.17-7.22 (m, 1H), 7.31-7.37 (AA'BB' m, 2H), 7.56-7.61 (AA'BB' m, 2H), 7.88-7.92 (AA'BB' m, 2H), 10.02 (s, 1H). ${ }^{13} \mathrm{C}$ NMR (75 MHz, $\left.\mathrm{CDCl}_{3}\right) \delta 55.4$ $\left(\mathrm{CH}_{3}\right), 69.3\left(\mathrm{CH}_{2}\right), 70\left(\mathrm{CH}_{2}\right), 102.4(\mathrm{CH}), 107.4(\mathrm{CH}), 107.8(\mathrm{CH}), 114.2(2 \times \mathrm{CH}), 127.6(2 \times \mathrm{CH})$, 
$129.0(\mathrm{C}), 129.4(2 \times \mathrm{CH}), 130.2(3 \times \mathrm{CH}), 136.1(\mathrm{C}), 144.1(\mathrm{C}), 159.6(\mathrm{C}), 159.7(\mathrm{C}), 160.3(\mathrm{C})$, $192.0(\mathrm{CH})$.

4-((3-((4-Formylbenzyl)oxy)phenoxy)methyl)benzonitrile (45). Following the procedure for 37, phenol 33 (357 $\mathrm{mg}, 1.59 \mathrm{mmol}$ ) was alkylated to give 45 (520 $\mathrm{mg}, 95 \%$ ) as a colourless solid. ${ }^{1} \mathrm{H}$ NMR $\left(300 \mathrm{MHz}, \mathrm{CDCl}_{3}\right) \delta 5.01(\mathrm{~s}, 2 \mathrm{H}), 5.13(\mathrm{~s}, 2 \mathrm{H}), 6.57-6.30(\mathrm{~m}, 3 \mathrm{H})$, 7.17-7.25 (m, 1H), 7.51-7.55 (AA'BB' m, 2H), 7.56-7.61 (AA'BB' m, 2H), 7.65-7.69 (AA'BB' m, 2H), 7.88-7.92 (AA'BB' m, 2H), $10.02(\mathrm{~s}, 1 \mathrm{H}) .{ }^{13} \mathrm{C} \mathrm{NMR}\left(75 \mathrm{MHz}, \mathrm{CDCl}_{3}\right) \delta 68.9\left(\mathrm{CH}_{2}\right), 69.2$ $\left(\mathrm{CH}_{2}\right), 102.3(\mathrm{CH}), 107.5(\mathrm{CH}), 107.7(\mathrm{CH}), 111.6(\mathrm{C}), 118.7(\mathrm{C}), 127.4(2 \times \mathrm{CH}), 127.5(2 \times \mathrm{CH})$, $130.0(2 \times \mathrm{CH}), 130.2(\mathrm{CH}), 132.3(2 \times \mathrm{CH}), 135.9(\mathrm{C}), 142.3(\mathrm{C}), 143.8(\mathrm{C}), 159.4(\mathrm{C}), 159.6(\mathrm{C})$, $191.8(\mathrm{CH})$.

4-((3-(Benzylthio)phenoxy)methyl)benzaldehyde (46). Following the procedure for $\mathbf{2 2}$, 4-(bromomethyl)benzaldehyde (301 mg, $1.51 \mathrm{mmol}$ ) and phenol 34 (336 mg, $1.55 \mathrm{mmol}$ ) gave 46 (401 mg, 79\%) as a colourless oil. ${ }^{1} \mathrm{H}$ NMR (400 MHz, $\left.\mathrm{CDCl}_{3}\right) \delta 4.11$ (s, 2H), 5.07 (s, 2H), 6.78 (ddd, $J=8.3,2.5$ and $0.8 \mathrm{~Hz}, 1 \mathrm{H}$ ), 6.89 (app. t, $J=2.1 \mathrm{~Hz}, 1 \mathrm{H}$ ), 6.94 (ddd, $J=7.7,1.6$ and $0.9 \mathrm{~Hz}$, 1H), $7.18(\mathrm{t}, J=8.0 \mathrm{~Hz}, 1 \mathrm{H}), 7.22-7.31(\mathrm{~m}, 5 \mathrm{H}), 7.55-7.58$ (AA'BB' $\mathrm{m}, 2 \mathrm{H}), 7.89-7.91$ (AA'BB' m, 2H), $10.03(\mathrm{~s}, 1 \mathrm{H}) .{ }^{13} \mathrm{C} \mathrm{NMR}\left(101 \mathrm{MHz}, \mathrm{CDCl}_{3}\right) \delta 38.9\left(\mathrm{CH}_{2}\right), 69.3\left(\mathrm{CH}_{2}\right), 113.1(\mathrm{CH}), 115.8$ $(\mathrm{CH}), 122.4(\mathrm{CH}), 127.4(\mathrm{CH}), 127.6(2 \times \mathrm{CH}), 128.7(2 \times \mathrm{CH}), 129.0(2 \times \mathrm{CH}), 129.9(\mathrm{CH}), 130.2$ $(2 \times \mathrm{CH}), 136.1(\mathrm{C}), 137.4(\mathrm{C}), 138.2(\mathrm{C}), 143.9(\mathrm{C}), 158.6(\mathrm{C}), 191.9(\mathrm{CH})$.

4-((3-((4-Fluorobenzyl)thio)phenoxy)methyl)benzaldehyde (47). Following the procedure for 22, 4-(bromomethyl)benzaldehyde (301 mg, $1.51 \mathrm{mmol})$ and phenol 35 (398 $\mathrm{mg}$, $1.70 \mathrm{mmol}$ ) gave $47(495 \mathrm{mg}, 93 \%)$ as a colourless oil. ${ }^{1} \mathrm{H} \mathrm{NMR}\left(400 \mathrm{MHz}, \mathrm{CDCl}_{3}\right) \delta 4.07(\mathrm{~s}, 2 \mathrm{H})$, 5.09 (s, 2H), 6.79 (ddd, $J=8.3,2.5$ and $0.8 \mathrm{~Hz}, 1 \mathrm{H}), 6.88$ (app. t, $J=2.1 \mathrm{~Hz}, 1 \mathrm{H}), 6.92$ (ddd, $J=$ 7.7, 1.7 and $0.9 \mathrm{~Hz}, 1 \mathrm{H}), 6.93-6.99(\mathrm{~m}, 2 \mathrm{H}), 7.19(\mathrm{t}, J=8.0 \mathrm{~Hz}, 1 \mathrm{H}), 7.21-7.26(\mathrm{~m}, 2 \mathrm{H}), 7.55-$ 
7.58 (AA'BB' m, 2H), 7.89-7.92 (AA'BB' m, 2H), 10.03 (s, 1H). ${ }^{13} \mathrm{C}$ NMR (101 MHz, $\left.\mathrm{CDCl}_{3}\right) \delta$ $38.1\left(\mathrm{CH}_{2}\right), 69.3\left(\mathrm{CH}_{2}\right), 113.1(\mathrm{CH}), 115.4(\mathrm{~d}, J=21.5 \mathrm{~Hz}, 2 \times \mathrm{CH}), 116.0(\mathrm{CH}), 122.6(\mathrm{CH}), 127.5$ $(2 \times \mathrm{CH}), 129.9(\mathrm{CH}), 130.1(2 \times \mathrm{CH}), 130.4(\mathrm{~d}, J=8.1 \mathrm{~Hz}, 2 \times \mathrm{CH}), 133.1(\mathrm{~d}, J=3.2 \mathrm{~Hz}, \mathrm{C}), 136.1$ (C), $137.7(\mathrm{C}), 158.6(\mathrm{C}), 162.1(\mathrm{~d}, J=245.8 \mathrm{~Hz}, \mathrm{C}), 191.9(\mathrm{CH}) .{ }^{19} \mathrm{~F}$ NMR $\left(376 \mathrm{MHz}, \mathrm{CDCl}_{3}\right) \delta$ -115.2 .

4-((3-((4-Chlorobenzyl)thio)phenoxy)methyl)benzaldehyde (48). Following the procedure for 22, 4-(bromomethyl)benzaldehyde $(300 \mathrm{mg}, 1.51 \mathrm{mmol}$ ) and phenol 36 (423 $\mathrm{mg}$, $1.69 \mathrm{mmol}$ ) gave 48 (468 mg, 84\%) as a colourless oil. ${ }^{1} \mathrm{H} \mathrm{NMR}\left(400 \mathrm{MHz}, \mathrm{CDCl}_{3}\right) \delta 4.05(\mathrm{~s}, 2 \mathrm{H})$, 5.07 (s, 2H), 6.79 (ddd, $J=8.3,2.5$ and $0.8 \mathrm{~Hz}, 1 \mathrm{H}), 6.86$ (app. t, $J=2.1 \mathrm{~Hz}, 1 \mathrm{H}), 6.92$ (ddd, $J=$ 7.7, 1.6 and $0.9 \mathrm{~Hz}, 1 \mathrm{H}), 7.15-7.26$ (m, 5H), 7.55-7.58 (AA'BB' m, 2H), 7.89-7.91 (AA'BB' m, 2H), $10.03(\mathrm{~s}, 1 \mathrm{H}) . .{ }^{13} \mathrm{C} \mathrm{NMR}\left(101 \mathrm{MHz}, \mathrm{CDCl}_{3}\right) \delta 38.1\left(\mathrm{CH}_{2}\right), 69.2\left(\mathrm{CH}_{2}\right), 113.2(\mathrm{CH}), 116.1$ $(\mathrm{CH}), 122.7(\mathrm{CH}), 127.5(2 \times \mathrm{CH}), 128.7(2 \times \mathrm{CH}), 129.9(\mathrm{CH}), 130.0(2 \times \mathrm{CH}), 130.2(2 \times \mathrm{CH}), 133.0$ (C), $136.0(\mathrm{C}), 136.1$ (C), 137.4 (C), 143.7 (C), $158.6(\mathrm{C}), 191.8(\mathrm{CH})$.

(R)-(1-(4-((3-(Benzyloxy)phenoxy)methyl)benzyl)pyrrolidin-2-yl)methanol (49). To a stirred solution of $37(254 \mathrm{mg}, 797 \mu \mathrm{mol})$ and $(R)$-prolinol $(170 \mathrm{mg}, 1.68 \mathrm{mmol})$ in anhydrous THF (15 mL) under argon was added $\mathrm{NaBH}(\mathrm{OAc})_{3}(347 \mathrm{mg}, 1.64 \mathrm{~mol})$. The mixture was sonicated, at ambient temperature for $3 \mathrm{~h}$. A further portion of $\mathrm{NaBH}(\mathrm{OAc})_{3}(214 \mathrm{mg}, 1.01 \mathrm{mmol})$ was then added and sonication of the turbid mixture continued for $40 \mathrm{~min}$. The mixture was stirred for $12 \mathrm{~h}$, then diluted with $2 \mathrm{M} \mathrm{NaOH}(\mathrm{aq})(40 \mathrm{~mL})$, vortexing thoroughly, and extracted with $\mathrm{CHCl}_{3}(250 \mathrm{~mL})$. The extract was dried $\left(\mathrm{MgSO}_{4}\right)$, evaporated and the residue processed chromatographically (20 g Strata ${ }^{\circledR}$ SI-1 cartridge; $2.5 \% \mathrm{MeOH} / \mathrm{CHCl}_{3}$ ). Target material eluted first, with $\mathrm{N}$-acetylprolinol ${ }^{55}$ overlapping in tail fractions. Fractions containing clean target material were combined and evaporated to afford $\mathbf{4 9}(225 \mathrm{mg}, 70 \%)$ as a colourless oil that became 
an amorphous solid on standing. ${ }^{1} \mathrm{H}$ NMR $\left(400 \mathrm{MHz}, \mathrm{CDCl}_{3}\right) \delta 1.66-1.75(\mathrm{~m}, 2 \mathrm{H}), 1.83-2.00(\mathrm{~m}$, 2H), $2.30(\mathrm{td}, J=9.3$ and $7.5 \mathrm{~Hz}, 1 \mathrm{H}), 2.50-3.00$ (br. s, $1 \mathrm{H}), 2.72-2.77(\mathrm{~m}, 1 \mathrm{H}), 2.97-3.01(\mathrm{~m}$, $1 \mathrm{H}), 3.38(\mathrm{~d}, J=13.1 \mathrm{~Hz}, 1 \mathrm{H}), 3.44(\mathrm{dd}, J=10.8$ and $2.1 \mathrm{~Hz}, 1 \mathrm{H}), 3.67(\mathrm{dd}, J=10.7$ and $3.5 \mathrm{~Hz}$, 1H), $3.98(\mathrm{~d}, J=13.1 \mathrm{~Hz}, 1 \mathrm{H}), 5.02(\mathrm{~s}, 2 \mathrm{H}), 5.05(\mathrm{~s}, 2 \mathrm{H}), 6.59-6.62(\mathrm{~m}, 2 \mathrm{H}), 6.64(\mathrm{t}, J=2.2 \mathrm{~Hz}$, 1H), 7.17-7.21 (m, 1H), 7.31-7.35 (m, 3H), 7.37-7.45 (m, 6H). ${ }^{13} \mathrm{C} \mathrm{NMR}\left(101 \mathrm{MHz}, \mathrm{CDCl}_{3}\right) \delta$ $23.5\left(\mathrm{CH}_{2}\right), 27.9\left(\mathrm{CH}_{2}\right), 54.5\left(\mathrm{CH}_{2}\right), 58.4\left(\mathrm{CH}_{2}\right), 62.1\left(\mathrm{CH}_{2}\right), 64.5(\mathrm{CH}), 69.9\left(\mathrm{CH}_{2}\right), 70.1\left(\mathrm{CH}_{2}\right)$, $102.4(\mathrm{CH}), 107.5(2 \times \mathrm{CH}), 127.5(2 \times \mathrm{CH}), 127.6(2 \times \mathrm{CH}), 128.0(\mathrm{CH}), 128.6(2 \times \mathrm{CH}), 128.9$ $(2 \times \mathrm{CH}), 130.0(\mathrm{CH}), 135.8(\mathrm{C}), 137.1(\mathrm{C}), 139.2(\mathrm{C}), 160.2(2 \times \mathrm{C})$. ESI-HRMS $[\mathrm{M}+\mathrm{H}]^{+}$calcd for $\mathrm{C}_{26} \mathrm{H}_{30} \mathrm{NO}_{3}{ }^{+}, 404.2220$; found, 404.2203. HPLC: Method (A) $\mathrm{t}_{\mathrm{R}} 4.56 \min$ (97.7\%). [Tail fractions from the chromatographic isolation of the product were combined separately to afford a second batch $(76.5 \mathrm{mg})$ of 53 contaminated with $12 \mathrm{~mol} \% \mathrm{~N}$-acetylprolinol, giving a total target material recovery of $93 \%$.]

\section{(R)-(1-(4-((3-((2-Fluorobenzyl)oxy)phenoxy)methyl)benzyl)pyrrolidin-2-yl)methanol}

(50). Following the procedure for 49, aldehyde 38 (261 mg, $776 \mu \mathrm{mol})$ afforded $\mathbf{5 0}(226 \mathrm{mg}, 69 \%)$ as a colourless oil that became an amorphous solid on standing. ${ }^{1} \mathrm{H}$ NMR $\left(400 \mathrm{MHz}, \mathrm{CDCl}_{3}\right) \delta$ 1.65-1.76 (m, 2H), 1.80-1.99 (m, 2H), $2.30(\mathrm{td}, J=9.2$ and $7.6 \mathrm{~Hz}, 1 \mathrm{H}), 2.50-3.00$ (br. s, $1 \mathrm{H})$, 2.72-2.77 (m, 1H), 2.96-3.01 (m, 1H), $3.38(\mathrm{~d}, J=13.1 \mathrm{~Hz}, 1 \mathrm{H}), 3.44(\mathrm{dd}, J=10.8$ and $2.1 \mathrm{~Hz}$, 1H), $3.67(\mathrm{dd}, J=10.8$ and $3.5 \mathrm{~Hz}, 1 \mathrm{H}), 3.98(\mathrm{~d}, J=13.1 \mathrm{~Hz}, 1 \mathrm{H}), 5.03(\mathrm{~s}, 2 \mathrm{H}), 5.12(\mathrm{~s}, 2 \mathrm{H}), 6.60-$ $6.63(\mathrm{~m}, 2 \mathrm{H}), 6.65(\mathrm{t}, J=2.3 \mathrm{~Hz}, 1 \mathrm{H}), 7.09(\mathrm{ddd}, J=9.9,8.4$ and $1.3 \mathrm{~Hz}, 1 \mathrm{H}), 7.16(\mathrm{td}, J=7.5$ and $1.2,1 \mathrm{H}), 7.20(\mathrm{t}, J=8.2,1 \mathrm{H}), 7.21-7.23(\mathrm{~m}, 3 \mathrm{H}), 7.37-7.40\left(\mathrm{AA}^{\prime} \mathrm{BB} ' \mathrm{~m}, 2 \mathrm{H}\right), 7.48-7.53(\mathrm{~m}, 1 \mathrm{H})$. ${ }^{13} \mathrm{C}$ NMR $\left(101 \mathrm{MHz}, \mathrm{CDCl}_{3}\right) \delta 23.5\left(\mathrm{CH}_{2}\right), 27.9\left(\mathrm{CH}_{2}\right), 54.5\left(\mathrm{CH}_{2}\right), 58.4\left(\mathrm{CH}_{2}\right), 62.0\left(\mathrm{CH}_{2}\right), 63.8$ $\left(\mathrm{d}, J=4.4 \mathrm{~Hz}, \mathrm{CH}_{2}\right), 64.5(\mathrm{CH}), 70.0\left(\mathrm{CH}_{2}\right), 102.4(\mathrm{CH}), 107.5(\mathrm{CH}), 107.8(\mathrm{CH}), 115.4(\mathrm{~d}, J=$ 21.2 Hz, CH), 124.27 (d, $J=$ ca.14 Hz, C), 124.30 (d, $J=3.6 \mathrm{~Hz}, \mathrm{CH}), 127.7(2 \times \mathrm{CH}), 129.0$ 
$(2 \times \mathrm{CH}), 129.7(\mathrm{~d}, J=8.7 \mathrm{~Hz}, \mathrm{CH}), 129.8(\mathrm{~d}, J=4.1 \mathrm{~Hz}, \mathrm{CH}), 130.0(\mathrm{CH}), 135.8(\mathrm{C}), 139.3(\mathrm{C})$, 159.9 (C), 160.2 (C), 160.5 (d, $J=246.9 \mathrm{~Hz}, \mathrm{C}) .{ }^{19} \mathrm{~F}$ NMR $\left(376 \mathrm{MHz}, \mathrm{CDCl}_{3}\right) \delta-118.6$. ESIHRMS $[\mathrm{M}+\mathrm{H}]^{+}$calcd for $\mathrm{C}_{26} \mathrm{H}_{29} \mathrm{FNO}_{3}{ }^{+}, 422.2126$ found, 422.2106. HPLC: Method (A) $\mathrm{t}_{\mathrm{R}} 4.62$ $\min (97.0 \%)$.

(R)-(1-(4-((3-((3-Fluorobenzyl)oxy)phenoxy)methyl)benzyl)pyrrolidin-2-yl)methanol (51). Following the procedure for 49, aldehyde 39 (258 mg, $768 \mu \mathrm{mol})$ afforded 51 (185 mg, 57\%) as a colourless oil. ${ }^{1} \mathrm{H}$ NMR $\left(400 \mathrm{MHz}, \mathrm{CDCl}_{3}\right) \delta 1.64-1.76(\mathrm{~m}, 2 \mathrm{H}), 1.80-1.99(\mathrm{~m}, 2 \mathrm{H}), 2.30(\mathrm{td}$, $J=9.3$ and $7.5 \mathrm{~Hz}, 1 \mathrm{H}), 2.40-2.90$ (br. s, $1 \mathrm{H}), 2.72-2.77(\mathrm{~m}, 1 \mathrm{H}), 2.96-3.01(\mathrm{~m}, 1 \mathrm{H}), 3.38(\mathrm{~d}, J=$ $13.1 \mathrm{~Hz}, 1 \mathrm{H}), 3.44(\mathrm{dd}, J=10.7$ and $1.8 \mathrm{~Hz}, 1 \mathrm{H}), 3.67(\mathrm{dd}, J=10.8$ and $3.5 \mathrm{~Hz}, 1 \mathrm{H}), 3.98(\mathrm{~d}, J=$ 13.1 Hz, 1H), $5.02(\mathrm{~s}, 2 \mathrm{H}), 5.04(\mathrm{~s}, 2 \mathrm{H}), 6.57-6.63(\mathrm{~m}, 3 \mathrm{H}), 6.98-7.04(\mathrm{~m}, 1 \mathrm{H}), 7.13-7.21(\mathrm{~m}$, 3H), 7.30-7.40 (m, 5H). ${ }^{13} \mathrm{C}$ NMR (101 MHz, $\left.\mathrm{CDCl}_{3}\right) \delta 23.5\left(\mathrm{CH}_{2}\right), 27.9\left(\mathrm{CH}_{2}\right), 54.6\left(\mathrm{CH}_{2}\right), 58.4$ $\left(\mathrm{CH}_{2}\right), 62.1\left(\mathrm{CH}_{2}\right), 64.5(\mathrm{CH}), 69.3\left(\mathrm{CH}_{2}\right), 70.0\left(\mathrm{CH}_{2}\right), 102.5(\mathrm{CH}), 107.5(\mathrm{CH}), 107.8(\mathrm{CH}), 114.3$ $(\mathrm{d}, J=21.9 \mathrm{~Hz}, \mathrm{CH}), 114.8(\mathrm{~d}, J=21.2 \mathrm{~Hz}, \mathrm{CH}), 122.8(\mathrm{~d}, J=2.9 \mathrm{~Hz}, \mathrm{CH}), 127.7(2 \times \mathrm{CH}), 129.0$ (2×CH), $130.1(\mathrm{CH}), 130.2(\mathrm{~d}, J=8.2 \mathrm{~Hz}, \mathrm{CH}), 135.8(\mathrm{C}), 139.3(\mathrm{C}), 139.8(\mathrm{~d}, J=7.3 \mathrm{~Hz}, \mathrm{C})$, 159.9 (C), 160.2 (C), $163.1(\mathrm{~d}, J=246.1 \mathrm{~Hz}, \mathrm{C}) .{ }^{19} \mathrm{~F}$ NMR $\left(376 \mathrm{MHz}, \mathrm{CDCl}_{3}\right) \delta-112.7$. ESIHRMS $[\mathrm{M}+\mathrm{H}]^{+}$calcd for $\mathrm{C}_{26} \mathrm{H}_{29} \mathrm{FNO}_{3}{ }^{+}, 422.2126$ found, 422.2106. HPLC: Method (A) $\mathrm{t}_{\mathrm{R}} 4.67$ $\min (>99 \%)$.

\section{(R)-(1-(4-((3-((4-Fluorobenzyl)oxy)phenoxy)methyl)benzyl)pyrrolidin-2-yl)methanol}

(52). Following the procedure for 49, aldehyde 40 (263 mg, $783 \mu \mathrm{mol})$ afforded 52 (239 $\mathrm{mg}, 73 \%)$ as a colourless oil. ${ }^{1} \mathrm{H}$ NMR $\left(400 \mathrm{MHz}, \mathrm{CDCl}_{3}\right) \delta 1.66-1.75(\mathrm{~m}, 2 \mathrm{H}), 1.80-1.99(\mathrm{~m}, 2 \mathrm{H}), 2.30(\mathrm{td}$, $J=9.3$ and $7.5 \mathrm{~Hz}, 1 \mathrm{H}), 2.50-3.00($ br. s, $1 \mathrm{H}), 2.72-2.77(\mathrm{~m}, 1 \mathrm{H}), 2.96-3.01(\mathrm{~m}, 1 \mathrm{H}), 3.38(\mathrm{~d}, J=$ $13.1 \mathrm{~Hz}, 1 \mathrm{H}), 3.44(\mathrm{dd}, J=10.8$ and $2.1 \mathrm{~Hz}, 1 \mathrm{H}), 3.67(\mathrm{dd}, J=10.8$ and $3.5 \mathrm{~Hz}, 1 \mathrm{H}), 3.98(\mathrm{~d}, J=$ $13.1 \mathrm{~Hz}, 1 \mathrm{H}), 5.00(\mathrm{~s}, 2 \mathrm{H}), 5.02(\mathrm{~s}, 2 \mathrm{H}), 6.57-6.62(\mathrm{~m}, 3 \mathrm{H}), 7.04-7.10(\mathrm{~m}, 2 \mathrm{H}), 7.17-7.22(\mathrm{~m}$, 
1H), 7.30-7.34 (AA'BB' m, 2H), 7.37-7.42 (m, 4H). $\left.{ }^{13} \mathrm{C} \mathrm{NMR} \mathrm{(101} \mathrm{MHz,} \mathrm{CDCl}_{3}\right) \delta 23.5\left(\mathrm{CH}_{2}\right)$, $27.9\left(\mathrm{CH}_{2}\right), 54.5\left(\mathrm{CH}_{2}\right), 58.4\left(\mathrm{CH}_{2}\right), 62.1\left(\mathrm{CH}_{2}\right), 64.5(\mathrm{CH}), 69.4\left(\mathrm{CH}_{2}\right), 70\left(\mathrm{CH}_{2}\right), 102.5(\mathrm{CH})$, $107.5(\mathrm{CH}), 107.6(\mathrm{CH}), 115.5(\mathrm{~d}, J=21.5 \mathrm{~Hz}, 2 \times \mathrm{CH}), 127.6(2 \times \mathrm{CH}), 129.0(2 \times \mathrm{CH}), 129.3(\mathrm{~d}, J$ $=8.2 \mathrm{~Hz}, 2 \times \mathrm{CH}), 130.0(\mathrm{CH}), 132.9(\mathrm{~d}, J=2.9 \mathrm{~Hz}, \mathrm{C}), 135.8(\mathrm{C}), 139.3(\mathrm{C}), 160.0(\mathrm{C}), 160.2(\mathrm{C})$, $162.5(\mathrm{~d}, J=246.1 \mathrm{~Hz}, \mathrm{C}) .{ }^{19} \mathrm{~F}$ NMR $\left(376 \mathrm{MHz}, \mathrm{CDCl}_{3}\right) \delta-114.27$. ESI-HRMS $[\mathrm{M}+\mathrm{H}]^{+}$calcd for $\mathrm{C}_{26} \mathrm{H}_{29} \mathrm{FNO}_{3}{ }^{+}$, 422.2126; found, 422.2105. HPLC: Method (A) $\mathrm{t}_{\mathrm{R}} 4.56 \min (>99 \%)$.

\section{(R)-(1-(4-((3-((2-Chlorobenzyl)oxy)phenoxy)methyl)benzyl)pyrrolidin-2-yl)methanol}

(53). Following the procedure for 49, aldehyde 41 (270 mg, $765 \mu \mathrm{mol})$ afforded 53 (196 mg, 58\%) as a colourless oil. ${ }^{1} \mathrm{H}$ NMR $\left(400 \mathrm{MHz}, \mathrm{CDCl}_{3}\right) \delta 1.64-1.76(\mathrm{~m}, 2 \mathrm{H}), 1.80-1.99(\mathrm{~m}, 2 \mathrm{H}), 2.29(\mathrm{td}$, $J=9.3$ and $7.6 \mathrm{~Hz}, 1 \mathrm{H}), 2.50-3.00$ (br. s, $1 \mathrm{H}), 2.72-2.77(\mathrm{~m}, 1 \mathrm{H}), 2.96-3.01(\mathrm{~m}, 1 \mathrm{H}), 3.37(\mathrm{~d}, J=$ $13.1 \mathrm{~Hz}, 1 \mathrm{H}), 3.44(\mathrm{dd}, J=10.7$ and $1.7 \mathrm{~Hz}, 1 \mathrm{H}), 3.67(\mathrm{dd}, J=10.7$ and $3.5 \mathrm{~Hz}, 1 \mathrm{H}), 3.98(\mathrm{~d}, J=$ $13.1 \mathrm{~Hz}, 1 \mathrm{H}), 5.03(\mathrm{~s}, 2 \mathrm{H}), 5.15(\mathrm{~s}, 2 \mathrm{H}), 6.60-6.32(\mathrm{~m}, 2 \mathrm{H}), 6.65(\mathrm{t}, J=2.2 \mathrm{~Hz}, 1 \mathrm{H}), 7.18-7.22$ (m, 1H), 7.24-7.29 (m, 2H), 7.30-7.33 (AA'BB' m, 2H), 7.37-7.41 (m overlapping AA'BB' m, 3H), 7.54-7.57 (m, 1H). ${ }^{13} \mathrm{C}$ NMR (101 MHz, $\left.\mathrm{CDCl}_{3}\right) \delta 23.5\left(\mathrm{CH}_{2}\right), 27.9\left(\mathrm{CH}_{2}\right), 54.5\left(\mathrm{CH}_{2}\right), 58.4$ $\left(\mathrm{CH}_{2}\right), 62.0\left(\mathrm{CH}_{2}\right), 64.5(\mathrm{CH}), 67.3\left(\mathrm{CH}_{2}\right), 70.0\left(\mathrm{CH}_{2}\right), 102.5(\mathrm{CH}), 107.6(\mathrm{CH}), 107.7(\mathrm{CH}), 127.0$ $(\mathrm{CH}), 127.7(2 \times \mathrm{CH}), 128.9(\mathrm{CH}), 128.96(2 \times \mathrm{CH}), 128.99(\mathrm{CH}), 129.4(\mathrm{CH}), 130.0(\mathrm{CH}), 132.6$ (C), 134.8 (C), 135.8 (C), 139.3 (C), 159.9 (C), 160.2 (C). ESI-HRMS [M + H] $]^{+}$calcd for $\mathrm{C}_{26} \mathrm{H}_{29} \mathrm{ClNO}_{3}{ }^{+}, 438.1831$ found, 438.1830. HPLC: Method (A) $\mathrm{t}_{\mathrm{R}} 5.00 \mathrm{~min}(>99 \%)$.

(R)-(1-(4-((3-((3-Chlorobenzyl)oxy)phenoxy)methyl)benzyl)pyrrolidin-2-yl)methanol

(54). Following the procedure for 49, aldehyde $42(253 \mathrm{mg}, 718 \mu \mathrm{mol})$ afforded 54 (158 mg, 50\%) as a colourless oil. ${ }^{1} \mathrm{H}$ NMR (400 MHz, $\left.\mathrm{CDCl}_{3}\right) \delta 1.63-1.77(\mathrm{~m}, 2 \mathrm{H}), 1.79-2.01(\mathrm{~m}, 2 \mathrm{H}), 2.30(\mathrm{td}$, $J=9.2$ and $7.5 \mathrm{~Hz}, 1 \mathrm{H}), 2.50-3.00$ (br. s, $1 \mathrm{H}), 2.71-2.78(\mathrm{~m}, 1 \mathrm{H}), 2.95-3.02(\mathrm{~m}, 1 \mathrm{H}), 3.38(\mathrm{~d}, J=$ $13.1 \mathrm{~Hz}, 1 \mathrm{H}), 3.44(\mathrm{dd}, J=10.8$ and $1.9 \mathrm{~Hz}, 1 \mathrm{H}), 3.67(\mathrm{dd}, J=10.7$ and $3.5 \mathrm{~Hz}, 1 \mathrm{H}), 3.98(\mathrm{~d}, J=$ 
$13.1 \mathrm{~Hz}, 1 \mathrm{H}), 5.01(\mathrm{~s}, 2 \mathrm{H}), 5.02(\mathrm{~s}, 2 \mathrm{H}), 6.56-6.63(\mathrm{~m}, 3 \mathrm{H}), 7.17-7.22(\mathrm{~m}, 1 \mathrm{H}), 7.28-7.34(\mathrm{~m}$, 5H), 7.36-7.40 (AA'BB' m, 2H), 7.42-7.44 (m, 1H). $\left.{ }^{13} \mathrm{C} \mathrm{NMR} \mathrm{(101} \mathrm{MHz,} \mathrm{CDCl}_{3}\right) \delta 23.6\left(\mathrm{CH}_{2}\right)$, $27.9\left(\mathrm{CH}_{2}\right), 54.6\left(\mathrm{CH}_{2}\right), 58.4\left(\mathrm{CH}_{2}\right), 62.0\left(\mathrm{CH}_{2}\right), 64.5(\mathrm{CH}), 69.3\left(\mathrm{CH}_{2}\right), 70.0\left(\mathrm{CH}_{2}\right), 102.5(\mathrm{CH})$, $107.5(\mathrm{CH}), 107.8(\mathrm{CH}), 125.4(\mathrm{CH}), 127.5(\mathrm{CH}), 127.7(2 \times \mathrm{CH}), 128.2(\mathrm{CH}), 129.0(2 \times \mathrm{CH}), 129.9$ (CH), $130.1(\mathrm{CH}), 134.6(\mathrm{C}), 135.8(\mathrm{C}), 139.2(\mathrm{C}), 139.4(\mathrm{C}), 159.9(\mathrm{C}), 160.2(\mathrm{C})$. ESI-HRMS $[\mathrm{M}+\mathrm{H}]^{+}$calcd for $\mathrm{C}_{26} \mathrm{H}_{29} \mathrm{ClNO}_{3}{ }^{+}, 438.1831$ found, 438.1808. HPLC: Method (A) $\mathrm{t}_{\mathrm{R}} 5.03 \min (>$ $99 \%)$.

\section{(R)-(1-(4-((3-((4-Chlorobenzyl)oxy)phenoxy)methyl)benzyl)pyrrolidin-2-yl)methanol}

(55). Following the procedure for 49, aldehyde 43 (267 mg, $757 \mu \mathrm{mol}$ ) afforded 55 (286 mg, 86\%) as a colourless oil that became an amorphous solid on standing. ${ }^{1} \mathrm{H}$ NMR $\left(400 \mathrm{MHz}, \mathrm{CDCl}_{3}\right) \delta$ $1.66-1.74(\mathrm{~m}, 2 \mathrm{H}), 1.81-2.00(\mathrm{~m}, 2 \mathrm{H}), 2.30$ (td, $J=9.3$ and $7.5 \mathrm{~Hz}, 1 \mathrm{H}), 2.60-2.95$ (br. s, $1 \mathrm{H})$, 2.72-2.77 (m, 1H), 2.97-3.01 (m, 1H), $3.38(\mathrm{~d}, J=13.1 \mathrm{~Hz}, 1 \mathrm{H}), 3.45(\mathrm{dd}, J=10.8$ and $2.0 \mathrm{~Hz}$, 1H), 3.67 (dd, $J=10.7$ and $3.5 \mathrm{~Hz}, 1 \mathrm{H}), 3.98(\mathrm{~d}, J=13.1 \mathrm{~Hz}, 1 \mathrm{H}), 5.00(\mathrm{~s}, 2 \mathrm{H}), 5.02(\mathrm{~s}, 2 \mathrm{H}), 6.58$ (dd, $J=8.2,2.3$ and $0.9 \mathrm{~Hz}, 1 \mathrm{H}), 6.60-6.63(\mathrm{~m}, 2 \mathrm{H}), 7.17-7.22(\mathrm{~m}, 1 \mathrm{H}), 7.30-7.41(\mathrm{~m}, 8 \mathrm{H}) .{ }^{13} \mathrm{C}$ NMR (75 MHz, $\left.\mathrm{CDCl}_{3}\right) \delta 23.5\left(\mathrm{CH}_{2}\right), 27.8\left(\mathrm{CH}_{2}\right), 54.5\left(\mathrm{CH}_{2}\right), 58.3\left(\mathrm{CH}_{2}\right), 61.9\left(\mathrm{CH}_{2}\right), 64.4(\mathrm{CH})$, $69.2\left(\mathrm{CH}_{2}\right), 69.9\left(\mathrm{CH}_{2}\right), 102.3(\mathrm{CH}), 107.4(\mathrm{CH}), 107.6(\mathrm{CH}), 127.7(2 \times \mathrm{CH}), 128.78(2 \times \mathrm{CH})$, $128.82(2 \times \mathrm{CH}), 129.0(2 \times \mathrm{CH}), 130.0(\mathrm{CH}), 133.8(\mathrm{C}), 135.5(\mathrm{C}), 135.7(\mathrm{C}), 139.3(\mathrm{C}), 159.8(\mathrm{C})$, 160.1 (C). ESI-HRMS [M + H] $]^{+}$calcd for $\mathrm{C}_{26} \mathrm{H}_{29} \mathrm{ClNO}_{3}{ }^{+}, 438.1831$; found, 438.1808. HPLC: Method (A) $t_{R} 5.15 \min (97.8 \%)$.

\section{(R)-(1-(4-((3-((4-methoxybenzyl)oxy)phenoxy)methyl)benzyl)pyrrolidin-2-}

yl)methanol (56). Following the procedure for 49, aldehyde 44 (256 mg, $735 \mu \mathrm{mol})$ afforded 56 (266 mg, 84\%) as a colourless oil that became an amorphous solid on standing. ${ }^{1} \mathrm{H}$ NMR (300 $\left.\mathrm{MHz}, \mathrm{CDCl}_{3}\right) \delta 1.65-1.75(\mathrm{~m}, 2 \mathrm{H}), 1.79-2.01(\mathrm{~m}, 2 \mathrm{H}), 2.30(\mathrm{td}, J=9.2$ and $7.6 \mathrm{~Hz}, 1 \mathrm{H}), 2.50-$ 
3.00 (br. s, $1 \mathrm{H}), 2.71-2.77(\mathrm{~m}, 1 \mathrm{H}), 2.95-3.02(\mathrm{~m}, 1 \mathrm{H}), 3.38(\mathrm{~d}, J=13.1 \mathrm{~Hz}, 1 \mathrm{H}), 3.44(\mathrm{dd}, J=$ 10.8 and $2.1 \mathrm{~Hz}, 1 \mathrm{H}), 3.67(\mathrm{dd}, J=10.8$ and $3.5 \mathrm{~Hz}, 1 \mathrm{H}), 3.82(\mathrm{~s}, 3 \mathrm{H}), 3.98(\mathrm{~d}, J=13.1 \mathrm{~Hz}, 1 \mathrm{H})$, $4.96(\mathrm{~s}, 2 \mathrm{H}), 5.02(\mathrm{~s}, 2 \mathrm{H}), 6.58-6.64(\mathrm{~m}, 3 \mathrm{H}), 6.90-6.94\left(\mathrm{AA}^{\prime} \mathrm{BB} ' \mathrm{~m}, 2 \mathrm{H}\right), 7.19(\mathrm{t}, J=8.2 \mathrm{~Hz}, 1 \mathrm{H})$, 7.31-7.40 (m, 6H). ${ }^{13} \mathrm{C} \mathrm{NMR}\left(75 \mathrm{MHz}, \mathrm{CDCl}_{3}\right) \delta 23.5\left(\mathrm{CH}_{2}\right), 27.8\left(\mathrm{CH}_{2}\right), 54.5\left(\mathrm{CH}_{2}\right), 55.4\left(\mathrm{CH}_{3}\right)$, $58.3\left(\mathrm{CH}_{2}\right), 61.9\left(\mathrm{CH}_{2}\right), 64.4(\mathrm{CH}), 69.86\left(\mathrm{CH}_{2}\right), 69.88\left(\mathrm{CH}_{2}\right), 102.3(\mathrm{CH}), 107.4(\mathrm{CH}), 107.5$ $(\mathrm{CH}), 114.1(2 \times \mathrm{CH}), 127.7(2 \times \mathrm{CH}), 128.97(2 \times \mathrm{CH}), 129.01(\mathrm{C}), 129.3(2 \times \mathrm{CH}), 130.0(\mathrm{CH}), 135.8$ (C), 139.2 (C), 159.5 (C), 160.1 (C), 160.2 (C). ESI-HRMS $[\mathrm{M}+\mathrm{H}]^{+}$calcd for $\mathrm{C}_{27} \mathrm{H}_{32} \mathrm{NO}_{4}{ }^{+}$, 434.2326; found, 434.2304. HPLC: Method (A) $t_{R} 4.61 \min (97.5 \%)$.

\section{(R)-4-((3-((4-((2-(hydroxymethyl)pyrrolidin-1-}

yl)methyl)benzyl)oxy)phenoxy)methyl)benzonitrile (57). Following the procedure for 49 , aldehyde $45(264 \mathrm{mg}, 768 \mu \mathrm{mol})$ afforded $57(124 \mathrm{mg}, 38 \%)$ as a colourless oil that became an amorphous solid on standing. ${ }^{1} \mathrm{H}$ NMR $\left(400 \mathrm{MHz}, \mathrm{CDCl}_{3}\right) \delta 1.65-1.76(\mathrm{~m}, 2 \mathrm{H}), 1.80-1.99(\mathrm{~m}$, 2H), $2.30(\mathrm{td}, J=9.3$ and $7.5 \mathrm{~Hz}, 1 \mathrm{H}), 2.50-3.00$ (br. s, $1 \mathrm{H}), 2.72-2.77(\mathrm{~m}, 1 \mathrm{H}), 2.96-3.01(\mathrm{~m}$, 1H), $3.38(\mathrm{~d}, J=13.1 \mathrm{~Hz}, 1 \mathrm{H}), 3.43(\mathrm{dd}, J=10.8$ and $2.0 \mathrm{~Hz}, 1 \mathrm{H}), 3.66(\mathrm{dd}, J=10.8$ and $3.5 \mathrm{~Hz}$, $1 \mathrm{H}), 3.97(\mathrm{~d}, J=13.1 \mathrm{~Hz}, 1 \mathrm{H}), 5.02(\mathrm{~s}, 2 \mathrm{H}), 5.10(\mathrm{~s}, 2 \mathrm{H}), 6.56(\mathrm{ddd}, J=8.2,2.4$ and $0.8 \mathrm{~Hz}, 1 \mathrm{H})$, $6.60(\mathrm{t}, J=2.2 \mathrm{~Hz}, 1 \mathrm{H}), 6.62(\mathrm{ddd}, J=8.2,2.4$ and $0.8 \mathrm{~Hz}, 1 \mathrm{H}), 7.18-7.22(\mathrm{~m}, 1 \mathrm{H}), 7.31-7.39$ (tight AA'BB' m, 4H), 7.52-7.54 (AA'BB' m, 2H), 7.66-7.69 (AA'BB' m, 2H). ${ }^{13} \mathrm{C}$ NMR (101 $\left.\mathrm{MHz}, \mathrm{CDCl}_{3}\right) \delta 23.5\left(\mathrm{CH}_{2}\right), 27.8\left(\mathrm{CH}_{2}\right), 54.5\left(\mathrm{CH}_{2}\right), 58.4\left(\mathrm{CH}_{2}\right), 62.0\left(\mathrm{CH}_{2}\right), 64.4(\mathrm{CH}), 69.0$ $\left(\mathrm{CH}_{2}\right), 70.0\left(\mathrm{CH}_{2}\right), 102.5(\mathrm{CH}), 107.4(\mathrm{CH}), 107.9(\mathrm{CH}), 111.7(\mathrm{C}), 118.6(\mathrm{C}), 127.55(2 \times \mathrm{CH})$, $127.58(2 \times \mathrm{CH}), 128.9(2 \times \mathrm{CH}), 130.1(\mathrm{CH}), 132.4(2 \times \mathrm{CH}), 135.6(\mathrm{C}), 139.4(\mathrm{C}), 142.5(\mathrm{C}), 159.5$ (C), 160.2 (C). ESI-HRMS [M + H] $]^{+}$calcd for $\mathrm{C}_{27} \mathrm{H}_{29} \mathrm{~N}_{2} \mathrm{O}_{3}{ }^{+}, 429.2173$ found, 429.2152. HPLC: Method (A) $t_{R} 4.25 \min (99.8 \%)$. 


\section{(R)-(1-(4-((3-(Benzylthio)phenoxy)methyl)benzyl)pyrrolidin-2-yl)methanol}

(58).

Following the procedure for 18, aldehyde 46 (401 mg, $1.20 \mathrm{mmol})$ afforded $\mathbf{5 8}(477 \mathrm{mg}, 95 \%)$ as a colourless oil that solidified on standing. ${ }^{1} \mathrm{H} \mathrm{NMR}\left(400 \mathrm{MHz}, \mathrm{CDCl}_{3}\right) \delta 1.65-1.76(\mathrm{~m}, 2 \mathrm{H}), 1.81-$ $2.00(\mathrm{~m}, 2 \mathrm{H}), 2.30(\mathrm{td}, J=9.3$ and $7.5 \mathrm{~Hz}, 1 \mathrm{H}), 2.50-3.00$ (br. s, $1 \mathrm{H}), 2.72-2.77(\mathrm{~m}, 1 \mathrm{H}), 2.96-$ $3.01(\mathrm{~m}, 1 \mathrm{H}), 3.38(\mathrm{~d}, J=13.1 \mathrm{~Hz}, 1 \mathrm{H}), 3.45(\mathrm{dd}, J=10.8$ and $1.8 \mathrm{~Hz}, 1 \mathrm{H}), 3.67(\mathrm{dd}, J=10.7$ and $3.5 \mathrm{~Hz}, 1 \mathrm{H}), 3.98(\mathrm{~d}, J=13.1 \mathrm{~Hz}, 1 \mathrm{H}), 4.11(\mathrm{~s}, 2 \mathrm{H}), 4.97(\mathrm{~s}, 2 \mathrm{H}), 6.80(\mathrm{dd}, J=8.3,2.3 \mathrm{and} 0.7 \mathrm{~Hz}$, 1H), 6.91-6.93 (m, 2H), 7.17 (app. t, $J=8.2 \mathrm{~Hz}, 1 \mathrm{H}), 7.22-7.38$ (m, 9H). ${ }^{13} \mathrm{C}$ NMR (101 MHz, $\left.\mathrm{CDCl}_{3}\right) \delta 23.6\left(\mathrm{CH}_{2}\right), 27.9\left(\mathrm{CH}_{2}\right), 38.9\left(\mathrm{CH}_{2}\right), 54.6\left(\mathrm{CH}_{2}\right), 58.3\left(\mathrm{CH}_{2}\right), 61.9\left(\mathrm{CH}_{2}\right), 64.4(\mathrm{CH}), 69.9$ $\left(\mathrm{CH}_{2}\right), 113.1(\mathrm{CH}), 115.8(\mathrm{CH}), 122.1(\mathrm{CH}), 127.3(\mathrm{CH}), 127.7(2 \times \mathrm{CH}), 128.6(2 \times \mathrm{CH}), 128.9$ $(2 \times \mathrm{CH}), 129.0(2 \times \mathrm{CH}), 129.8(\mathrm{CH}), 135.6(\mathrm{C}), 137.4(\mathrm{C}), 137.9(\mathrm{C}), 139.4(\mathrm{C}), 159.0(\mathrm{C})$. ESIHRMS [M + H] $]^{+}$calcd for $\mathrm{C}_{26} \mathrm{H}_{30} \mathrm{NO}_{2} \mathrm{~S}^{+}$, 420.1992; found, 420.1995. HPLC: Method (A) $\mathrm{t}_{\mathrm{R}} 4.61$ $\min (>99 \%)$.

\section{(R)-(1-(4-((3-((4-Fluorobenzyl)thio)phenoxy)methyl)benzyl)pyrrolidin-2-yl)methanol}

(59). Following the procedure for 18, aldehyde 47 (487 mg, $1.38 \mathrm{mmol})$ afforded 59 (471 $\mathrm{mg}$, $78 \%$ ) as a colourless oil. ${ }^{1} \mathrm{H}$ NMR $\left(400 \mathrm{MHz}, \mathrm{CDCl}_{3}\right) \delta 1.65-1.73(\mathrm{~m}, 2 \mathrm{H}), 1.80-1.99(\mathrm{~m}, 2 \mathrm{H})$, $2.29(\mathrm{td}, J=9.3$ and $7.5 \mathrm{~Hz}, 1 \mathrm{H}), 2.60-2.85$ (br m, 1H), 2.71-2.77 (m, 1H), 2.95-3.01 (m, 1H), $3.37(\mathrm{~d}, J=13.1 \mathrm{~Hz}, 1 \mathrm{H}), 3.44(\mathrm{dd}, J=10.8$ and $1.8 \mathrm{~Hz}, 1 \mathrm{H}), 3.66(\mathrm{dd}, J=10.7$ and $3.5 \mathrm{~Hz}, 1 \mathrm{H})$, $3.97(\mathrm{~d}, J=13.1 \mathrm{~Hz}, 1 \mathrm{H}), 4.07(\mathrm{~s}, 2 \mathrm{H}), 4.98(\mathrm{~s}, 2 \mathrm{H}), 6.80(\mathrm{ddd}, J=8.3,2.3$ and $1.1 \mathrm{~Hz}, 1 \mathrm{H}), 6.88-$ $6.91(\mathrm{~m}, 2 \mathrm{H}), 6.93-6.99(\mathrm{~m}, 2 \mathrm{H}), 7.15-7.19(\mathrm{~m}, 1 \mathrm{H}), 7.21-7.25(\mathrm{~m}, 2 \mathrm{H}), 7.31-7.37$ (tight AA'BB' m, 4H). ${ }^{13} \mathrm{C}$ NMR (101 MHz, $\left.\mathrm{CDCl}_{3}\right) \delta 23.6\left(\mathrm{CH}_{2}\right), 27.9\left(\mathrm{CH}_{2}\right), 38.3\left(\mathrm{CH}_{2}\right), 54.6\left(\mathrm{CH}_{2}\right), 58.4$ $\left(\mathrm{CH}_{2}\right), 62.0\left(\mathrm{CH}_{2}\right), 64.5(\mathrm{CH}), 70.0\left(\mathrm{CH}_{2}\right), 113.4(\mathrm{CH}), 115.4(\mathrm{~d}, J=21.5 \mathrm{~Hz}, 2 \times \mathrm{CH}), 116.3(\mathrm{CH})$, $122.5(\mathrm{CH}), 127.7(2 \times \mathrm{CH}), 129.0(2 \times \mathrm{CH}), 129.8(\mathrm{CH}), 130.5(\mathrm{~d}, J=8.1 \mathrm{~Hz}, 2 \times \mathrm{CH}), 133.3(\mathrm{~d}, J=$ $2.9 \mathrm{~Hz}, \mathrm{C}), 135.7$ (C), 137.5 (C), 139.5 (C), 159.1 (C), 162.2 (d, J=245.5 Hz, C). ${ }^{19} \mathrm{~F}$ NMR (282 
$\left.\mathrm{MHz}, \mathrm{CDCl}_{3}\right) \delta$-115.2. ESI-HRMS $[\mathrm{M}+\mathrm{H}]^{+}$calcd for $\mathrm{C}_{26} \mathrm{H}_{29} \mathrm{FNO}_{2} \mathrm{~S}^{+}$, 438.1898; found, 438.1891. HPLC: Method (A) $t_{R} 4.94 \min (95.4 \%)$.

(R)-(1-(4-((3-((4-Chlorobenzyl)thio)phenoxy)methyl)benzyl)pyrrolidin-2-

yl)methanol (60). Following the procedure for 18, aldehyde 48 (100 $\mathrm{mg}, 0.260 \mathrm{mmol})$ afforded 60 (62 mg, 53\%) as a colourless oil. ${ }^{1} \mathrm{H}$ NMR (400 MHz, $\left.\mathrm{CDCl}_{3}\right) \delta 1.66-1.74(\mathrm{~m}, 2 \mathrm{H}), 1.80-1.99$ (m, 2H), 2.29 (td, $J=9.3$ and $7.5 \mathrm{~Hz}, 1 \mathrm{H}), 2.50-2.85$ (br m, 1H), 2.72-2.77 (m, 1H), 2.95-3.00 (m, 1H), $3.38(\mathrm{~d}, J=13.1 \mathrm{~Hz}, 1 \mathrm{H}), 3.44(\mathrm{dd}, J=10.8$ and $2.2 \mathrm{~Hz}, 1 \mathrm{H}), 3.67(\mathrm{dd}, J=10.8$ and 3.5 $\mathrm{Hz}, 1 \mathrm{H}), 3.98(\mathrm{~d}, J=13.1 \mathrm{~Hz}, 1 \mathrm{H}), 4.05(\mathrm{~s}, 2 \mathrm{H}), 4.98(\mathrm{~s}, 2 \mathrm{H}), 6.81(\mathrm{ddd}, J=8.3,2.4$ and $1.1 \mathrm{~Hz}$, 1H), 6.88-6.91 (m, 2H), 7.15-7.22 (m, 3H), 7.23-7.26 (m, 2H), 7.31-7.37 (tight AA'BB' m, 4H). ${ }^{13} \mathrm{C} \mathrm{NMR}\left(101 \mathrm{MHz}, \mathrm{CDCl}_{3}\right) \delta 23.6\left(\mathrm{CH}_{2}\right), 27.9\left(\mathrm{CH}_{2}\right), 38.4\left(\mathrm{CH}_{2}\right), 54.6\left(\mathrm{CH}_{2}\right), 58.4\left(\mathrm{CH}_{2}\right), 62.0$ $\left(\mathrm{CH}_{2}\right), 64.51(\mathrm{CH}), 70.0\left(\mathrm{CH}_{2}\right), 113.5(\mathrm{CH}), 116.4(\mathrm{CH}), 122.6(\mathrm{CH}), 127.7(2 \times \mathrm{CH}), 128.7$ $(2 \times \mathrm{CH}), 129.0(2 \times \mathrm{CH}), 129.9(\mathrm{CH}), 130.2(2 \times \mathrm{CH}), 133.1(\mathrm{C}), 135.7(\mathrm{C}), 136.2(\mathrm{C}), 137.2(\mathrm{C})$, 139.5 (C), 159.2 (C). ESI-HRMS [M + H] $]^{+}$calcd for $\mathrm{C}_{26} \mathrm{H}_{29} \mathrm{ClNO}_{2} \mathrm{~S}^{+}$, 454.1602; found, 454.1603. HPLC: Method (A) $t_{R} 5.27 \min (98.8 \%)$.

Molecular modeling. An SK2 homology model was constructed in order to provide a qualitative understanding of ligand selectivity determinants. The preliminary model was generated through the SWISS-MODEL server ${ }^{47-50}$ by submission of the SK2 sequence and specification of the SK1/PF-543 co-crystal structure (4V24 chain A, $1.8 \AA$ resolution) ${ }^{38}$ as a template. In SK1 a regulatory 'R-loop' ( 41 residues) is interposed between strands $\beta 9 / \beta 10$ of the CTD and makes no contact with the 3 lipid binding loops that pack to form the J-channel on the opposite face of the CTD core $\beta$-sandwich. (See supplementary Figure S1 in Adams et al ${ }^{39}$ for SK1/SK2 sequence alignment and definition of loops.) The R-loop in SK2 is substantially longer (156 residues) and, in the absence of a suitable template, no attempt was made to model it. Thus, the core of this loop 
sequence (SK2 residues 345-488 inclusive) was deleted. The implicit assumption, that the R-loop does not directly impact on the structure of the J-channel heel and toe regions, was deemed reasonable based on the known disposition of the R-loop in SK1 crystal structures. The length of the lipid binding loops is identical for SK1 and SK2 and the loops exhibit a high degree of sequence conservation: LBL-1 (34 residues), 62\% identity; LBL-2 (21 residues), 43\% identity; LBL-3 (28 residues), 61\% identity. Very close structural homology observed between the SK2 model output from the SWISS-MODEL server and the SK1 template was therefore fully reasonable.

The model was refined using the protein preparation and refinement tools in the Small Molecule Drug Discovery (SMDD) software suite from Schrödinger, LLC. Ramachandran plot analysis of the crude model (lacking the R-loop) identified 4 residues (Ser209, Ala523, Thr578, Pro579) with outlier $\varphi$ and $\psi$ angle combinations. These were considered sufficiently remote from the J-channel to have little bearing on the quality of the model as starting point for refinement. Hydration from the template protein (4V24) was merged into the model together with a J-channel ligand, SKi (10), from its co-crystal structure (3VZC, chain A) aligned to the crude model. The latter was selected as a suitable J-channel ligand for refinement work because it inhibits both SK1 and SK2 with little discrimination and because the structure of the SK1 J-channel is conserved when bound by PF-543 or SKi. The hydroxymethyl group of PF-543 mimics the 3-OH of Sph substrate in engaging Asp308 on helix- $\alpha$ 7. In its absence, as with bound SKi, the position of the hydroxyl is occupied by a surrogate water, defined as W2 in Figure S3 of Adams et al ${ }^{39}$. A water was therefore inserted into the W2 position of the crude model with SKi. The model was manually inspected and waters imported from the 4V24 template that were sterically interdicted were deleted or moved to take account of side chain conformations. 
The C-terminal end of the less strongly conserved LBL-2 was remodelled with a template taken from residues 209-PEAQVDDGKLHL-220 in the crystal structure (4WER) of a prokaryotic diacylglycerol kinase family protein. These residues correspond to 521-PHARFDDGLVHL-532 in SK2 and 276-PMGRCA $\underline{A G V M H L-287 ~ i n ~ S K 1 . ~ I n ~ t h e ~ 4 W E R ~ s t r u c t u r e, ~ t h e ~ r e s i d u e s ~ i n ~ t h i s ~}$ sequence form a well-defined lariat which is highly conserved across related crystal structures (2BON, 2JGR, 2P1R, 2QV7, 2QVL, 3S40, 3T5P, 4WRR). In several of these the lariat hosts a non-catalytic metal ion by coordination to an aspartate in a DG motif that is conserved in all the structures and also in SK2 but not in SK1. Where present, the metal ion is also coordinated by a conserved aspartate on one of two long crossed $\beta$-strands that form the key interdomain connection. This latter residue (Asp281) is also conserved in SK2 but not conserved in SK1, where the cognate residue is Asn151. When the metal ion is absent, a structural water molecule acts as a surrogate through hydrogen bonded interactions, as is the case in the 4WER crystal structure. The metal ion may have a regulatory role in the prokaryotic enzymes. ${ }^{56,57}$ At present there is no evidence to support a role for non-catalytic metal ion regulatory control over SK2, and we therefore modelled the SK2 lariat on the metal-free structure of 4WER.

To refine the model, preparation was undertaken with the SMDD protein preparation wizard using default optimisation and restrained minimisation routines. Full OPLS3 force field protein minimisation was then undertaken in iterations, initially with SK1-templated Cartesian constraints on selected residues lining the interdomain cleft, at the interdomain tip interface of LBL-1 and at the hinge of LBL-3. The constraints were defined to restrain interdomain movement and to mimic a helix-capping interaction seen in SK1 crystal structures from Arg291 on LBL3/helix- $\alpha 9$ (conserved as Arg541 in SK2) to the backbone at the C-terminal end of LBL-1/helix$\alpha 8$. The constraints were progressively removed following the initial minimisation with the 
remodelled LBL-2 loop structure and omitted altogether in the final minimisation. Ramachandran plot analysis of the minimsed model identified no residues with outlier $\varphi$ and $\psi$ angle combinations. Standard precision (Glide SP) docking routines within SMDD were employed for ligand docking using grids generated with SKi as the binding site identifier. Docked structures were then processed with the SMDD Prime refine protein-ligand complex utility using local optimisation settings within an $8 \AA$ radius of the ligand. In the case of VT20dd (9), initial ligand docking was undertaken with the smaller analogue, (protonated) (S)-2-((3-(4-)((4-(3(trifluoromethyl)phenyl)thiazol-2-yl)amino)phenyl)-1,2,4-oxadiazol-5-yl)methyl)pyrrolidine-1carboximidamide (compound $\mathbf{2 0 1}$ in Childress et al), ${ }^{36}$ to define a binding mode for the core and polar head group of this SK inhibitor chemotype. The ligand in the resulting model was then rebuilt using the SMDD build tools and subjected to the SMDD Prime refine protein-ligand complex routine.

\section{ASSOCIATED CONTENT}

\section{Supporting Information}

The Supporting Information is available free of charge on the ACS Publications website at DOI: . Molecular formula strings with SK1 and SK2 inhibition data (si_01.csv). Related to Figures 5, 7 and 8, homology model of SK2 with compound 60 (si_02.pdb). Related to Figure 6, homology model of SK2 with compound 49 (si_03.pdb). Related to Figure 6, docking model of SK1 (based on crystal structure PDB: 4V24) with compound 49 (si_04.pdb).

Related to Figure 7, docking model of SK1 (based on crystal structure PDB: 4V24) with compound 60 (si_05.pdb).

Related to Figure 8, homology model of SK2 with compound 9 (si_06.pdb). 
Related to Figure 8, homology model of SK2 with compound 10 (si_07.pdb).

Reference NMR spectra for key compounds (si_08.pdf)

\author{
AUTHOR INFORMATION \\ Corresponding Author \\ *E-mail: susan.pyne@strath.ac.uk. Tel: +44(0)141 5482012 \\ ORCID
}

Susan Pyne: 0000-0002-6608-9584

Author Contributions

The manuscript was written through contributions of all authors. All authors have given approval to the final version of the manuscript.

\title{
Funding Sources
}

This research is part funded by the MSD Scottish Life Sciences fund. As part of an on-going contribution to Scottish life sciences, Merck Sharp \& Dohme Limited (MSD), a global healthcare leader, has given substantial monetary funding to the Scottish Funding Council (SFC) for distribution via the Scottish Universities Life Science Alliance (SULSA) to develop and deliver a high-quality drug discovery research and training programme. All aspects of the programme have been geared towards attaining the highest value in terms of scientific discovery, training and impact. The opinions expressed in this research are those of the authors and do not represent those of MSD, nor its Affiliates. ST also thanks the Libyan Government for a sponsored $\mathrm{PhD}$ studentship.

\section{Notes}

The authors declare no competing financial interests. 


\begin{abstract}
ABBREVIATIONS
Cer, ceramide; CTD, C-terminal domain; HDAC1/2, histone deacetylases 1/2; LBL, lipid binding loop; NTD, N-terminal domain; R-loop, regulatory loop; S1P, sphingosine 1-phosphate; SK1, sphingosine kinase 1; SK2, sphingosine kinase 2; Sph, sphingosine.
\end{abstract}

\title{
REFERENCES
}

(1) Garris, C. S.; Blaho, V. A.; Hla, T.; Han, M. H. Sphingosine-1-phosphate receptor 1 signalling in T cells: trafficking and beyond. Immunology 2014, 142, 347-353.

(2) Hait, N. C.; Allegood, J.; Maceyka, M.; Strub, G. M.; Harikumar, K. B.; Singh, S. K.; Luo, C.; Marmorstein, R.; Kordula, T.; Milstien, S.; Spiegel, S. Regulation of histone acetylation in the nucleus by sphingosine-1-phosphate. Science 2009, 325, 1254-1257.

(3) Degagne, E.; Pandurangan, A.; Bandhuvula, P.; Kumar, A.; Eltanawy, A.; Zhang, M.; Yoshinaga, Y.; Nefedov, M.; de Jong, P. J.; Fong, L. G.; Young, S. G.; Bittman, R.; Ahmedi, Y.; Saba, J. D. Sphingosine-1-phosphate lyase downregulation promotes colon carcinogenesis through STAT3-activated microRNAs. J. Clin. Invest. 2014, 124, 5368-5384.

(4) Mandala, S. M.; Thornton, R.; Galve-Roperh, I.; Poulton, S.; Peterson, C.; Olivera, A.; Bergstrom, J.; Kurtz, M. B.; Spiegel, S. Molecular cloning and characterization of a lipid phosphohydrolase that degrades sphingosine-1-phosphate and induces cell death. Proc. Natl. Acad. Sci. USA 2000, 97, 7859-7864.

(5) Mandala, S. M. Sphingosine-1-phosphate phosphatases. Prostaglandins 2001, 64, 143156.

(6) Ogawa, C.; Kihara, A.; Gokoh, M.; Igarashi, Y. Identification and characterization of a novel human sphingosine-1-phosphate phosphohydrolase, hSPP2. J. Biol. Chem. 2003, 278, 12681272. 
(7) Siow, D.; Wattenberg, B. The compartmentalization and translocation of the sphingosine kinases: mechanisms and functions in cell signaling and sphingolipid metabolism. Crit. Rev. Biochem. Mol. Biol. 2011, 46, 365-375.

(8) Hannun, Y. A.; Obeid, L. M. Principles of bioactive lipid signalling: lessons from sphingolipids. Nat. Rev. Mol. Cell Biol. 2008, 9, 139-150.

(9) Zheng, W.; Kollmeyer, J.; Symolon, H.; Momin, A.; Munter, E.; Wang, E.; Kelly, S.; Allegood, J. C.; Liu, Y.; Peng, Q.; Ramaraju, H.; Sullards, M. C.; Cabot, M.; Merrill, A. H., Jr. Ceramides and other bioactive sphingolipid backbones in health and disease: lipidomic analysis, metabolism and roles in membrane structure, dynamics, signaling and autophagy. Biochim. Biophys. Acta 2006, 1758, 1864-1884.

(10) Pyne, S.; Chapman, J.; Steele, L.; Pyne, N. J. Sphingomyelin-derived lipids differentially regulate the extracellular signal-regulated kinase 2 (ERK-2) and c-Jun N-terminal kinase (JNK) signal cascades in airway smooth muscle. Eur. J. Biochem. 1996, 237, 819-826.

(11) Cuvillier, O.; Pirianov, G.; Kleuser, B.; Vanek, P. G.; Coso, O. A.; Gutkind, S.; Spiegel, S. Suppression of ceramide-mediated programmed cell death by sphingosine-1-phosphate. Nature 1996, 381, 800-803.

(12) Newton, J.; Lima, S.; Maceyka, M.; Spiegel, S. Revisiting the sphingolipid rheostat: Evolving concepts in cancer therapy. Exp. Cell Res. 2015, 333, 195-200.

(13) Pyne, S.; Adams, D. R.; Pyne, N. J. Sphingosine kinases as druggable targets. In Handb. Exp. Pharmacol., Springer, Berlin, Heidelberg: 2018.

(14) Pyne, S.; Adams, D. R.; Pyne, N. J. Sphingosine 1-phosphate and sphingosine kinases in health and disease: recent advances. Prog. Lipid Res. 2016, 62, 93-106. 
(15) Neubauer, H. A.; Pitson, S. M. Roles, regulation and inhibitors of sphingosine kinase 2. FEBS J. 2013, 280, 5317-5336.

(16) Baker, D. L.; Pham, T. C.; Sparks, M. A. Structure and catalytic function of sphingosine kinases: analysis by site-directed mutagenesis and enzyme kinetics. Biochim. Biophys. Acta 2013, $1831,139-146$.

(17) Pitman, M. R.; Powell, J. A.; Coolen, C.; Moretti, P. A.; Zebol, J. R.; Pham, D. H.; Finnie, J. W.; Don, A. S.; Ebert, L. M.; Bonder, C. S.; Gliddon, B. L.; Pitson, S. M. A selective ATPcompetitive sphingosine kinase inhibitor demonstrates anti-cancer properties. Oncotarget 2015, 6, 7065-7083.

(18) Schnute, M. E.; McReynolds, M. D.; Kasten, T.; Yates, M.; Jerome, G.; Rains, J. W.; Hall, T.; Chrencik, J.; Kraus, M.; Cronin, C. N.; Saabye, M.; Highkin, M. K.; Broadus, R.; Ogawa, S.; Cukyne, K.; Zawadzke, L. E.; Peterkin, V.; Iyanar, K.; Scholten, J. A.; Wendling, J.; Fujiwara, H.; Nemirovskiy, O.; Wittwer, A. J.; Nagiec, M. M. Modulation of cellular S1P levels with a novel, potent and specific inhibitor of sphingosine kinase-1. Biochem. J. 2012, 444, 79-88.

(19) Xiang, Y.; Hirth, B.; Kane, J. L., Jr.; Liao, J.; Noson, K. D.; Yee, C.; Asmussen, G.; Fitzgerald, M.; Klaus, C.; Booker, M. Discovery of novel sphingosine kinase-1 inhibitors. Part 2. Bioorg. Med. Chem. Lett. 2010, 20, 4550-4554.

(20) Gustin, D. J.; Li, Y.; Brown, M. L.; Min, X.; Schmitt, M. J.; Wanska, M.; Wang, X.; Connors, R.; Johnstone, S.; Cardozo, M.; Cheng, A. C.; Jeffries, S.; Franks, B.; Li, S.; Shen, S.; Wong, M.; Wesche, H.; Xu, G.; Carlson, T. J.; Plant, M.; Morgenstern, K.; Rex, K.; Schmitt, J.; Coxon, A.; Walker, N.; Kayser, F.; Wang, Z. Structure guided design of a series of sphingosine kinase (SphK) inhibitors. Bioorg. Med. Chem. Lett. 2013, 23, 4608-4616. 
(21) Zhang, Y.; Berka, V.; Song, A.; Sun, K.; Wang, W.; Zhang, W.; Ning, C.; Li, C.; Zhang, Q.; Bogdanov, M.; Alexander, D. C.; Milburn, M. V.; Ahmed, M. H.; Lin, H.; Idowu, M.; Zhang, J.; Kato, G. J.; Abdulmalik, O. Y.; Zhang, W.; Dowhan, W.; Kellems, R. E.; Zhang, P.; Jin, J.; Safo, M.; Tsai, A. L.; Juneja, H. S.; Xia, Y. Elevated sphingosine-1-phosphate promotes sickling and sickle cell disease progression. J. Clin. Invest. 2014, 124, 2750-2761.

(22) Zhang, F.; Xia, Y.; Yan, W.; Zhang, H.; Zhou, F.; Zhao, S.; Wang, W.; Zhu, D.; Xin, C.; Lee, Y.; Zhang, L.; He, Y.; Gao, E.; Tao, L. Sphingosine 1-phosphate signaling contributes to cardiac inflammation, dysfunction, and remodeling following myocardial infarction. Am. J. Physiol. Heart Circ. Physiol. 2016, 310, H250-H261.

(23) MacRitchie, N.; Volpert, G.; Al Washih, M.; Watson, D. G.; Futerman, A. H.; Kennedy, S.; Pyne, S.; Pyne, N. J. Effect of the sphingosine kinase 1 selective inhibitor, PF-543 on arterial and cardiac remodelling in a hypoxic model of pulmonary arterial hypertension. Cell. Signal. 2016, $28,946-955$.

(24) French, K. J.; Zhuang, Y.; Maines, L. W.; Gao, P.; Wang, W.; Beljanski, V.; Upson, J. J.; Green, C. L.; Keller, S. N.; Smith, C. D. Pharmacology and antitumor activity of ABC294640, a selective inhibitor of sphingosine kinase-2. J. Pharmacol. Exp. Ther. 2010, 333, 129-139.

(25) Liu, K.; Guo, T. L.; Hait, N. C.; Allegood, J.; Parikh, H. I.; Xu, W.; Kellogg, G. E.; Grant, S.; Spiegel, S.; Zhang, S. Biological characterization of 3-(2-aminoethyl)-5-[3-(4butoxylphenyl)propylidene]thiazolidine-2,4-dione (K145) as a selective sphingosine kinase-2 inhibitor and anticancer agent. PLoS One 2013, 8, e56471.

(26) Kharel, Y.; Raje, M.; Gao, M.; Gellett, A. M.; Tomsig, J. L.; Lynch, K. R.; Santos, W. L. Sphingosine kinase type 2 inhibition elevates circulating sphingosine 1-phosphate. Biochem. J. 2012, 447, 149-157. 
(27) Lim, K. G.; Sun, C.; Bittman, R.; Pyne, N. J.; Pyne, S. (R)-FTY720 methyl ether is a specific sphingosine kinase 2 inhibitor: effect on sphingosine kinase 2 expression in HEK 293 cells and actin rearrangement and survival of MCF-7 breast cancer cells. Cell. Signal. 2011, 23, 15901595.

(28) Beljanski, V.; Knaak, C.; Smith, C. D. A novel sphingosine kinase inhibitor induces autophagy in tumor cells. J. Pharmacol. Exp. Ther. 2010, 333, 454-464.

(29) Fitzpatrick, L. R.; Green, C.; Frauenhoffer, E. E.; French, K. J.; Zhuang, Y.; Maines, L. W.; Upson, J. J.; Paul, E.; Donahue, H.; Mosher, T. J.; Smith, C. D. Attenuation of arthritis in rodents by a novel orally-available inhibitor of sphingosine kinase. Inflammopharmacology 2011, $19,75-87$.

(30) Maines, L. W.; Fitzpatrick, L. R.; Green, C. L.; Zhuang, Y.; Smith, C. D. Efficacy of a novel sphingosine kinase inhibitor in experimental Crohn's disease. Inflammopharmacology 2010, $18,73-85$.

(31) Venant, H.; Rahmaniyan, M.; Jones, E. E.; Lu, P.; Lilly, M. B.; Garrett-Mayer, E.; Drake, R. R.; Kraveka, J. M.; Smith, C. D.; Voelkel-Johnson, C. The sphingosine kinase 2 inhibitor ABC294640 reduces the growth of prostate cancer cells and results in accumulation of dihydroceramides in vitro and in vivo. Mol. Cancer Ther. 2015, 14, 2744-2752.

(32) McNaughton, M.; Pitman, M.; Pitson, S. M.; Pyne, N. J.; Pyne, S. Proteasomal degradation of sphingosine kinase 1 and inhibition of dihydroceramide desaturase by the sphingosine kinase inhibitors, SKi or ABC294640, induces growth arrest in androgen-independent LNCaP-AI prostate cancer cells. Oncotarget 2016, 7, 16663-16675.

(33) Alsanafi, M.; Kelly, S. L.; Jubair, K.; McNaughton, M.; Tate, R. J.; Merrill, A. H., Jr.; Pyne, S.; Pyne, N. J. Native and polyubiquitinated forms of dihydroceramide desaturase are 
differentially linked to human embryonic kidney cell survival. Mol. Cell. Biol. 2018, 38, e0022218.

(34) Evangelisti, C.; Evangelisti, C.; Teti, G.; Chiarini, F.; Falconi, M.; Melchionda, F.; Pession, A.; Bertaina, A.; Locatelli, F.; McCubrey, J. A.; Beak, D. J.; Bittman, R.; Pyne, S.; Pyne, N. J.; Martelli, A. M. Assessment of the effect of sphingosine kinase inhibitors on apoptosis, unfolded protein response and autophagy of T-cell acute lymphoblastic leukemia cells; indications for novel therapeutics. Oncotarget 2014, 5, 7886-7901.

(35) Schnute, M. E.; McReynolds, M. D.; Carroll, J.; Chrencik, J. E.; Highkin, M. K.; Iyanar, K.; Jerome, G.; Rains, J. W.; Saabye, M.; Scholten, J. A.; Yates, M.; Nagiec, M. M. Discovery of a potent and selective sphingosine kinase 1 inhibitor through the molecular combination of chemotype distinct screening hits. J. Med. Chem. 2017, 60, 2562-2572.

(36) Childress, E. S.; Kharel, Y.; Brown, A. M.; Bevan, D. R.; Lynch, K. R.; Santos, W. L. Transforming sphingosine kinase 1 inhibitors into dual and sphingosine kinase 2 selective inhibitors: design, synthesis, and in vivo activity. J. Med. Chem. 2017, 60, 3933-3957.

(37) Wang, Z.; Min, X.; Xiao, S. H.; Johnstone, S.; Romanow, W.; Meininger, D.; Xu, H.; Liu, J.; Dai, J.; An, S.; Thibault, S.; Walker, N. Molecular basis of sphingosine kinase 1 substrate recognition and catalysis. Structure 2013, 21, 798-809.

(38) Wang, J.; Knapp, S.; Pyne, N. J.; Pyne, S.; Elkins, J. M. Crystal Structure of sphingosine kinase 1 with PF-543. ACS Med. Chem. Lett. 2014, 5, 1329-1333.

(39) Adams, D. R.; Pyne, S.; Pyne, N. J. Sphingosine kinases: emerging structure-function insights. Trends Biochem. Sci. 2016, 41, 395-409. 
(40) Cinelli, M. A.; Li, H.; Pensa, A. V.; Kang, S.; Roman, L. J.; Martasek, P.; Poulos, T. L.; Silverman, R. B. Phenyl ether- and aniline-containing 2-aminoquinolines as potent and selective inhibitors of neuronal nitric oxide synthase. J. Med. Chem. 2015, 58, 8694-8712.

(41) Byun, H.-S.; Pyne, S.; MacRitchie, N.; Pyne, N. J.; Bittman, R. Novel sphingosinecontaining analogues selectively inhibit sphingosine kinase (SK) isozymes, induce SK1 proteasomal degradation and reduce DNA synthesis in human pulmonary arterial smooth muscle cells. MedChemComm 2013, 4, 1394-1399.

(42) Edsall, L. C.; Van Brocklyn, J. R.; Cuvillier, O.; Kleuser, B.; Spiegel, S. N,NDimethylsphingosine is a potent competitive inhibitor of sphingosine kinase but not of protein kinase C: modulation of cellular levels of sphingosine 1-phosphate and ceramide. Biochemistry 1998, 37, 12892-12898.

(43) Hengst, J. A.; Guilford, J. M.; Conroy, E. J.; Wang, X.; Yun, J. K. Enhancement of sphingosine kinase 1 catalytic activity by deletion of 21 amino acids from the COOH-terminus. Arch. Biochem. Biophys. 2010, 494, 23-31.

(44) Lim, K. G.; Tonelli, F.; Li, Z.; Lu, X.; Bittman, R.; Pyne, S.; Pyne, N. J. FTY720 analogues as sphingosine kinase 1 inhibitors: enzyme inhibition kinetics, allosterism, proteasomal degradation, and actin rearrangement in MCF-7 breast cancer cells. J. Biol. Chem. 2011, 286, $18633-18640$.

(45) Jones, L. H.; Summerhill, N. W.; Swain, N. A.; Mills, J. E. Aromatic chloride to nitrile transformation: medicinal and synthetic chemistry. Med. Chem. Commun. 2010, 1, 309-318.

(46) Fleming, F. F.; Yao, L.; Ravikumar, P. C.; Funk, L.; Shook, B. C. Nitrile-containing pharmaceuticals: efficacious roles of the nitrile pharmacophore. J. Med. Chem. 2010, 53, 79027917. 
(47) Arnold, K.; Bordoli, L.; Kopp, J.; Schwede, T. The SWISS-MODEL workspace: a webbased environment for protein structure homology modelling. Bioinformatics 2006, 22, 195-201. (48) Kiefer, F.; Arnold, K.; Kunzli, M.; Bordoli, L.; Schwede, T. The SWISS-MODEL Repository and associated resources. Nucleic Acids Res. 2009, 37, D387-D392.

(49) Guex, N.; Peitsch, M. C.; Schwede, T. Automated comparative protein structure modeling with SWISS-MODEL and Swiss-PdbViewer: a historical perspective. Electrophoresis 2009, 30 Suppl 1, S162-S173.

(50) Biasini, M.; Bienert, S.; Waterhouse, A.; Arnold, K.; Studer, G.; Schmidt, T.; Kiefer, F.; Gallo Cassarino, T.; Bertoni, M.; Bordoli, L.; Schwede, T. SWISS-MODEL: modelling protein tertiary and quaternary structure using evolutionary information. Nucleic Acids Res. 2014, 42, W252-W258.

(51) Congdon, M. D.; Kharel, Y.; Brown, A. M.; Lewis, S. N.; Bevan, D. R.; Lynch, K. R.; Santos, W. L. Structure-activity relationship studies and molecular modeling of naphthalene-based sphingosine kinase 2 Inhibitors. ACS Med. Chem. Lett. 2016, 7, 229-234.

(52) Houck, J. D.; Dawson, T. K.; Kennedy, A. J.; Kharel, Y.; Naimon, N. D.; Field, S. D.; Lynch, K. R.; Macdonald, T. L. Structural requirements and docking analysis of amidine-based sphingosine kinase 1 inhibitors containing oxadiazoles. ACS Med. Chem. Lett. 2016, 7, 487-492.

(53) Fang, L.; Wang, X.; Xi, M.; Liu, T.; Yin, D. Assessing the ligand selectivity of sphingosine kinases using molecular dynamics and MM-PBSA binding free energy calculations. Mol. Biosyst. 2016, 12, 1174-1182.

(54) Gottlieb, H. E.; Kotlyar, V.; Nudelman, A. NMR chemical shifts of common laboratory solvents as trace impurities. J. Org. Chem. 1997, 62, 7512-7515. 
(55) Bishop, J. E.; Mathis, C. A.; Gerdes, J. M.; Whitney, J. M.; Eaton, A. M.; Mailman, R. B. Synthesis and in vitro evaluation of 2,3-dimethoxy-5-(fluoroalkyl)-substituted benzamides: highaffinity ligands for CNS dopamine D2 receptors. J. Med. Chem. 1991, 34, 1612-1624.

(56) Bakali, H. M.; Herman, M. D.; Johnson, K. A.; Kelly, A. A.; Wieslander, A.; Hallberg, B. M.; Nordlund, P. Crystal structure of YegS, a homologue to the mammalian diacylglycerol kinases, reveals a novel regulatory metal binding site. J. Biol. Chem. 2007, 282, 19644-19652.

(57) Abe, T.; Lu, X.; Jiang, Y.; Boccone, C. E.; Qian, S.; Vattem, K. M.; Wek, R. C.; Walsh, J. P. Site-directed mutagenesis of the active site of diacylglycerol kinase alpha: calcium and phosphatidylserine stimulate enzyme activity via distinct mechanisms. Biochem. J. 2003, 375, $673-680$. 
Table of Contents graphic

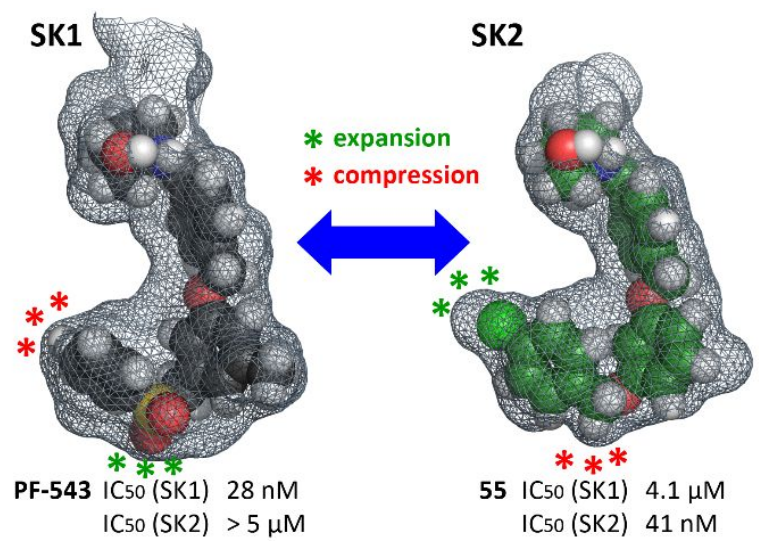


(a)

Page 71 of 82 Journal of Mediainal Chemistry

11

12

1
2
3

(b)
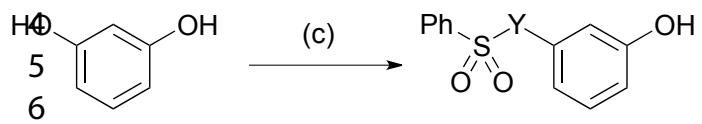

$7 \quad 13$

8

$14 \quad \mathrm{Y}=\mathrm{CH}_{2} \quad$ (77\% from 12)

9

$15 \quad Y=O \quad$ (21\% from 13)

(d)

11

12

13

14

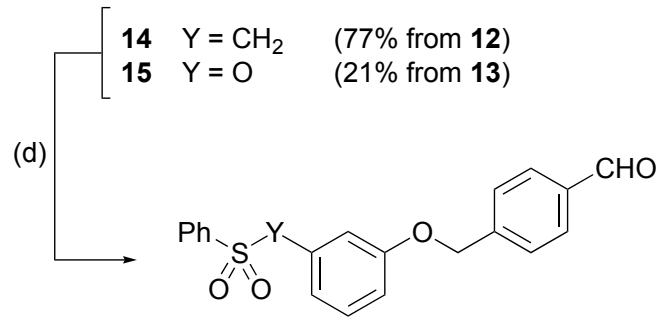

15

16

$16 \quad \mathrm{Y}=\mathrm{CH}_{2} \quad$ (81\% from 14)

17

$17 \quad \mathrm{Y}=\mathrm{O} \quad$ (88\% from 15)

18

19

20

21

22

(e)

23

24

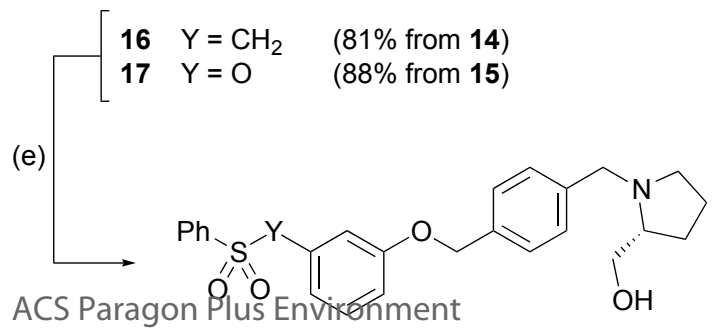

$18 \quad \mathrm{Y}=\mathrm{CH}_{2} \quad$ (71\% from 16)

$19 \quad Y=O \quad(33 \%$ from 17$)$ 
Page 73 of 82 Journal of Atediginal Chemistry<smiles>Oc1ccc(O)c(I)c1</smiles>

(a) or (b)

$23 \mathrm{~A}=\mathrm{OH}$

$34 \mathrm{~A}=\mathrm{SH}$

4

5

6

7

8

9

10

11

12

13

14

15

16

17

18

19

20

21

22

23

24

25

26

27

28

29

30

31

32

33

34

35

36

37

38

39

40

41

42

43

(c) or (d)$$
25 \quad \mathrm{Y}=\mathrm{O} \quad \mathrm{X}=\mathrm{H} \quad \text { (55\% from 13) }
$$

$26 \quad Y=O \quad X=O-F \quad$ (53\% from 13)

$27 \quad Y=O \quad X=m-F \quad$ (58\% from 13)

$28 \quad \mathrm{Y}=\mathrm{O} \quad \mathrm{X}=p-\mathrm{F} \quad$ (38\% from 13)

$29 \quad \mathrm{Y}=\mathrm{O} \quad \mathrm{X}=0-\mathrm{Cl} \quad$ (54\% from 13)

$30 \quad \mathrm{Y}=\mathrm{O} \quad \mathrm{X}=m-\mathrm{Cl} \quad$ (49\% from 13)

$31 \quad \mathrm{Y}=\mathrm{O} \quad \mathrm{X}=p-\mathrm{Cl} \quad$ (48\% from 13)

$32 \quad Y=O \quad X=p$-OMe (32\% from 13)

$33 \quad Y=O \quad X=p-C N \quad$ (47\% from 13)

$34 \quad Y=S \quad X=H \quad$ (68\% from 24)

$35 \quad \mathrm{Y}=\mathrm{S} \quad \mathrm{X}=p-\mathrm{F} \quad$ (71\% from 24)

$36 \quad \mathrm{Y}=\mathrm{S} \quad \mathrm{X}=p-\mathrm{Cl} \quad$ (79\% from 24)

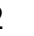

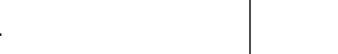

$\longrightarrow$

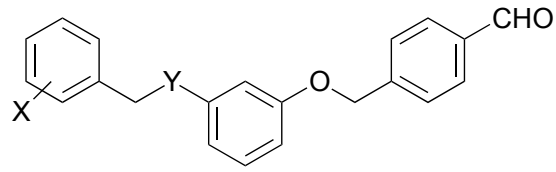

(17

$37 \quad \mathrm{Y}=\mathrm{O} \quad \mathrm{X}=\mathrm{H} \quad$ (88\% from 25)

$38 \quad Y=O \quad X=O-F \quad$ (62\% from 26)

$39 \quad Y=O \quad X=m-F \quad$ (64\% from 27)

$40 \quad Y=O \quad X=p-F \quad$ (77\% from 28)

$41 \quad \mathrm{Y}=\mathrm{O} \quad \mathrm{X}=\mathrm{o}-\mathrm{Cl} \quad$ (71\% from 29)

$42 \quad \mathrm{Y}=\mathrm{O} \quad \mathrm{X}=m-\mathrm{Cl} \quad$ (55\% from 30)

$43 \quad \mathrm{Y}=\mathrm{O} \quad \mathrm{X}=p-\mathrm{Cl} \quad$ (96\% from 31)

$44 \quad Y=O \quad X=p$-OMe (68\% from 32)

$45 \quad Y=O \quad X=p-C N \quad$ (95\% from 33)

$46 \quad Y=S \quad X=H \quad$ (79\% from 34)

(e) $\quad\left[\begin{array}{llll}47 & \mathrm{Y}=\mathrm{S} & \mathrm{X}=p-\mathrm{F} & (93 \% \text { from } 35) \\ 48 & \mathrm{Y}=\mathrm{S} & \mathrm{X}=p-\mathrm{Cl} & (84 \% \text { from } 36)\end{array}\right.$

(e) $\quad\left[\begin{array}{llll}47 & \mathrm{Y}=\mathrm{S} & \mathrm{X}=p-\mathrm{F} & (93 \% \text { from } 35) \\ 48 & \mathrm{Y}=\mathrm{S} & \mathrm{X}=p-\mathrm{Cl} & (84 \% \text { from } 36)\end{array}\right.$

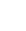

(3)

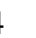

5

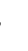

8

39

0

\section{1}

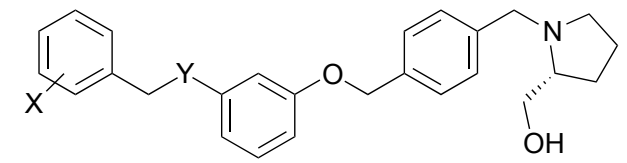

$49 \quad \mathrm{Y}=\mathrm{O} \quad \mathrm{X}=\mathrm{H} \quad$ (70\% from 37)

$50 \quad \mathrm{Y}=\mathrm{O} \quad \mathrm{X}=0-\mathrm{F} \quad$ (69\% from 38)

$51 \quad \mathrm{Y}=\mathrm{O} \quad \mathrm{X}=m-\mathrm{F} \quad$ (57\% from 39$)$

$52 \quad \mathrm{Y}=\mathrm{O} \quad \mathrm{X}=p-\mathrm{F} \quad(73 \%$ from 40$)$

$53 \quad \mathrm{Y}=\mathrm{O} \quad \mathrm{X}=0-\mathrm{Cl} \quad$ (58\% from 41)

$54 \quad \mathrm{Y}=\mathrm{O} \quad \mathrm{X}=m-\mathrm{Cl} \quad$ (50\% from 42)

$55 \quad \mathrm{Y}=\mathrm{O} \quad \mathrm{X}=p-\mathrm{Cl} \quad$ (86\% from 43)

$56 \quad \mathrm{Y}=\mathrm{O} \quad \mathrm{X}=p$-OMe (84\% from 44$)$

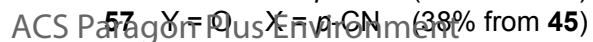

$58 \quad \mathrm{Y}=\mathrm{S} \quad \mathrm{X}=\mathrm{H} \quad$ (95\% from 46$)$

$59 \quad \mathrm{Y}=\mathrm{S} \quad \mathrm{X}=p-\mathrm{F} \quad$ (78\% from 47$)$

$60 \quad \mathrm{Y}=\mathrm{S} \quad \mathrm{X}=p-\mathrm{Cl} \quad(53 \%$ from 48$)$ 


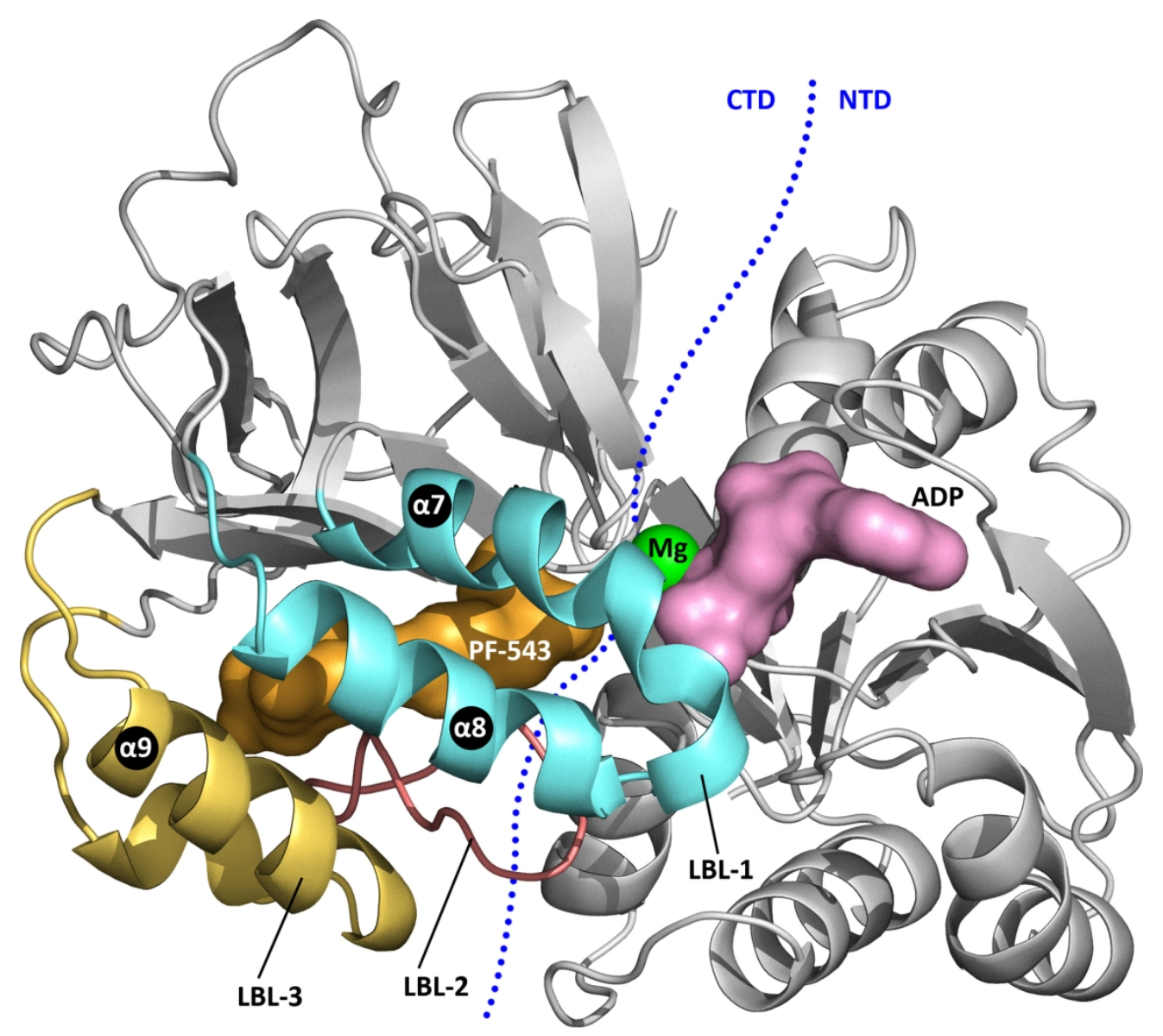

Figure 1. The structure of SK1 is shown with bound PF-543 (1; orange surface) (PDB: 4V24). PF-543 occupies the substrate Sph binding site, formed by the packing of three lipid binding loops (LBL-1 to LBL-3) against a $\beta$-sandwich core. The nucleotide binding site is shown by superimposition of Mg-ADP (green sphere/rose surface) from its separate co-crystal structure (3VZD) with SK1.

$80 \times 71 \mathrm{~mm}(600 \times 600 \mathrm{DPI})$ 


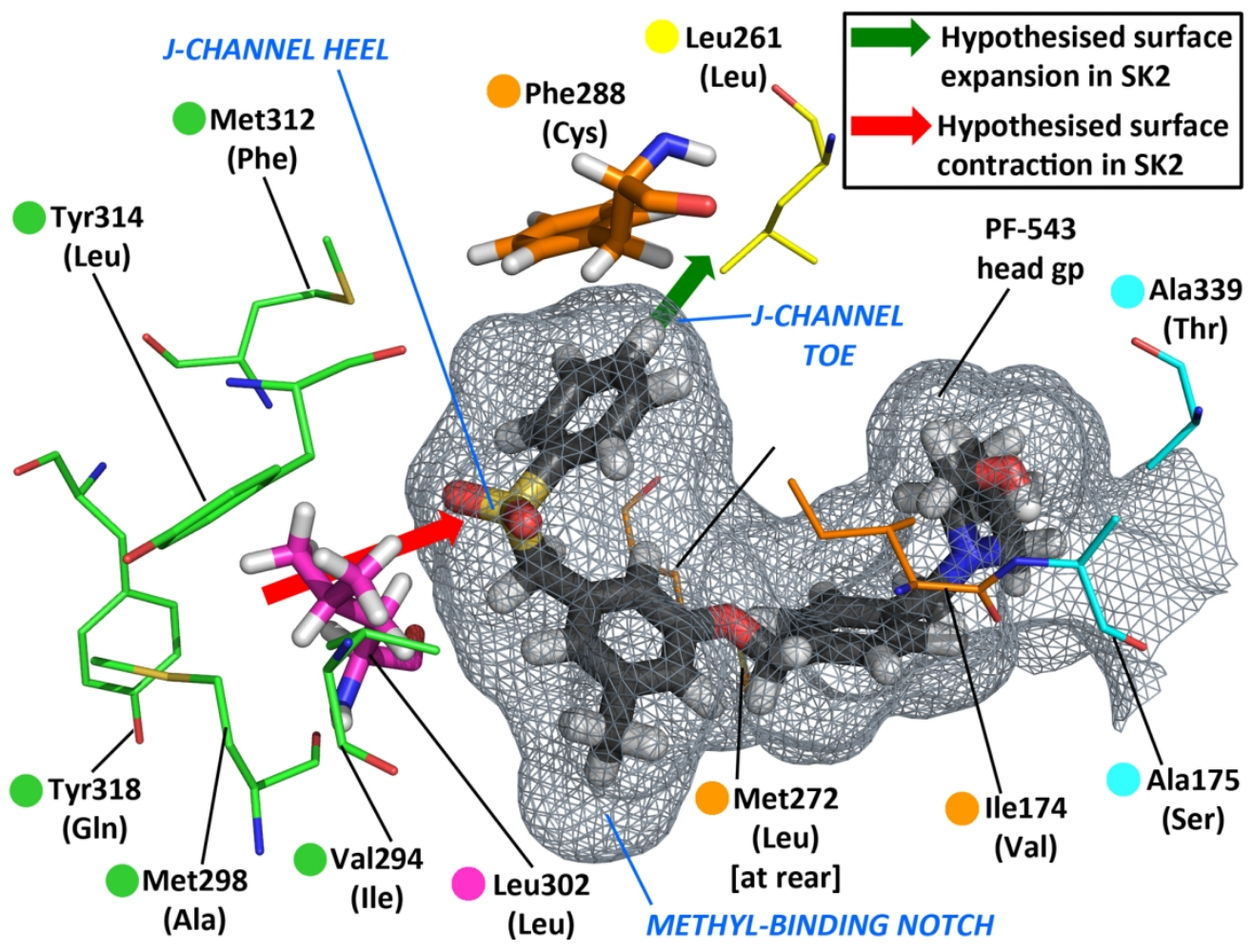

Figure 2. J-channel surface detail (mesh) from the PF-543/SK1 co-crystal (PDB: 4V24), highlighting key isoform residue differences that likely impact on the J-channel struc-ture of SK2. SK1 residue numbering is shown; cognate SK2 residues, where different, are in parenthesis. (Residue color notation: see text.)

$79 \times 59 \mathrm{~mm}(600 \times 600 \mathrm{DPI})$ 


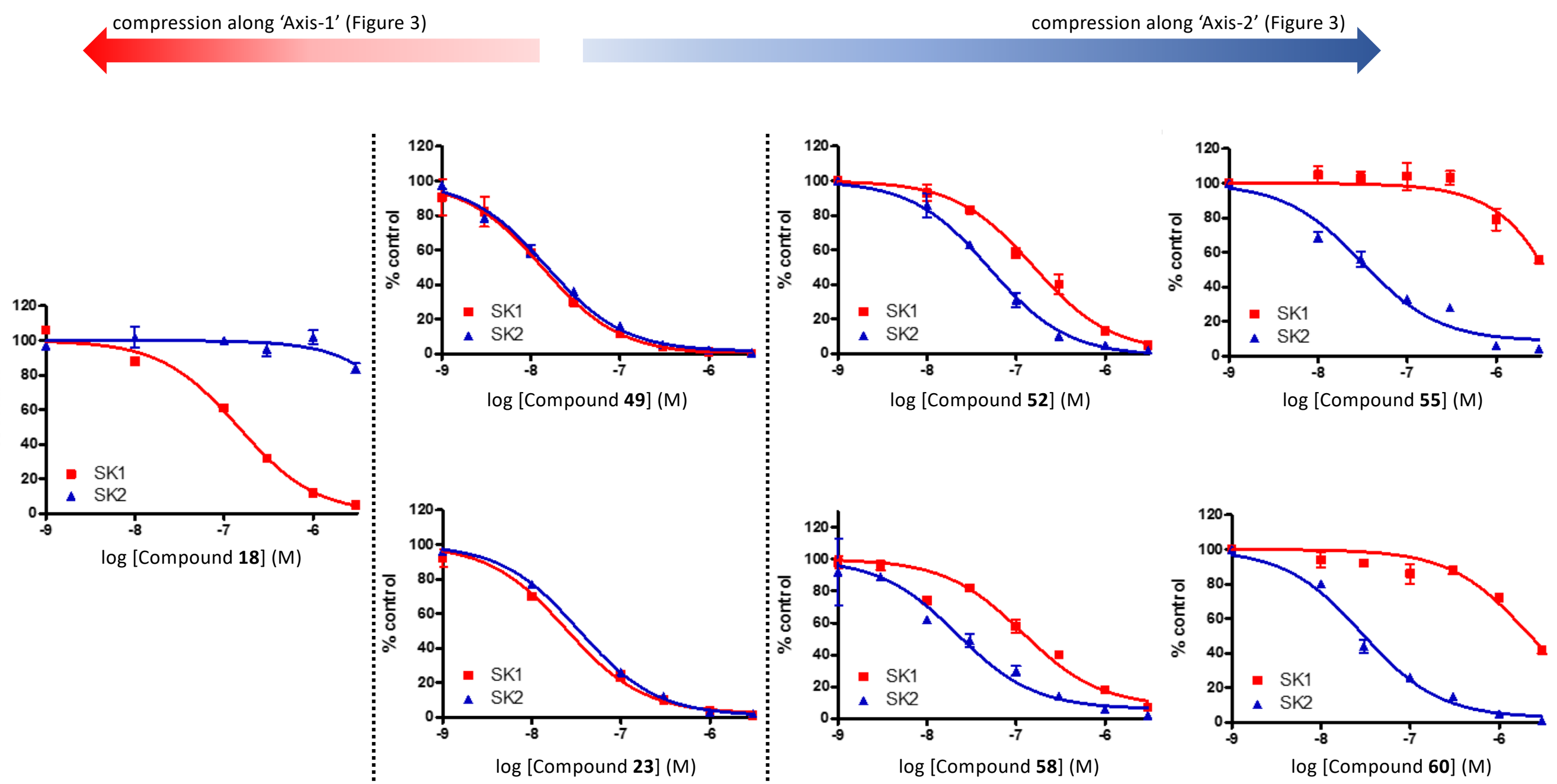


(A)

60/SK2 mode

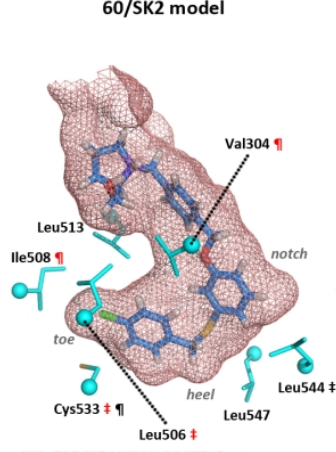

SK2: TOE EXPANSION POSSIBLE
(B)

PF-543/SK1 co-crystal structure

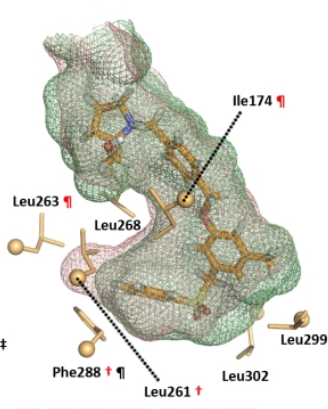

SK1: TOE EXPANSION CONSTRAINED
(C)

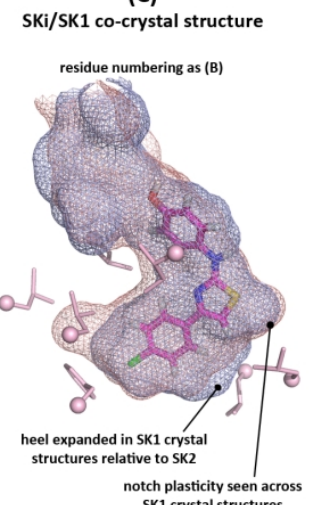

(D)

overlay (A)-(C)

If sequence difference between SK1 / SK2 isoform

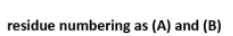

residue numbering as (A) and (B)

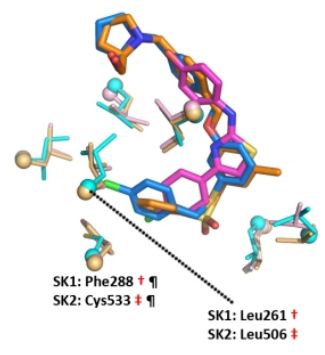

Figure 5. Comparison of modelled binding mode for SK2-selective inhibitor 60 with SK1 co-crystal structures of PF-543 (1) and SKi (10). Panel (A): 60 (blue stick) docked into SK2 model (red mesh), highlighting key contact residues (cyan stick) and ex-panded SK2 J-channel toe surface. Panel (B): PF-543

(1; orange stick) is shown from its co-crystal structure (4V24) with SK1 (green mesh) and the SK2 model surface (red mesh) overlaid from (A); SK1 contact residues are shown (light orange stick) and the constrained SK1 J-channel toe surface is evident. Panel (C): As (B), but showing co-crystal structure (3VZD) of SKi (10, magenta stick) with SK1 (blue mesh and pink stick key contact residues) superimposed onto the SK2 model (red mesh) from panel (A); the heel region adjacent to SK1 Leu302 is consistently less compressed in SK1 structures (relative to the SK2 model), whilst the notch surface exhibits some plasticity. Panel (D): overlay of $(A)-(C)$ minus the J-channel surface; the chlorine atom of 60 is ac-commodated in SK2 between Cys588 and Leu506, with rotation of the latter possible whilst the cognate SK1 residue (Leu261) is constrained by the packing of adjacent residues. 
(A)

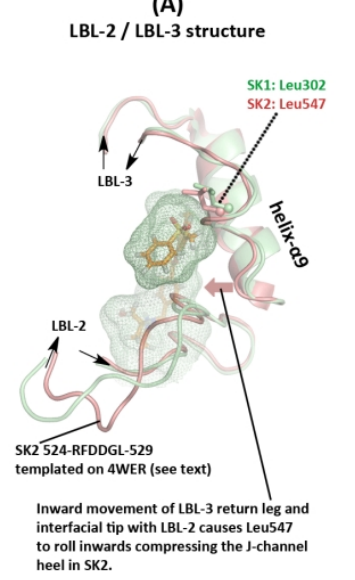

(B)

49/SK2 model

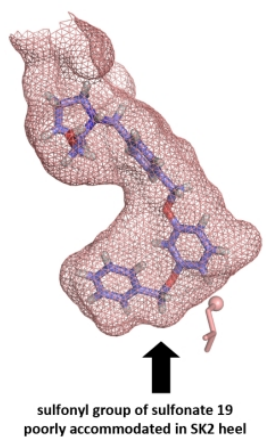

(C)

49/SK1 model

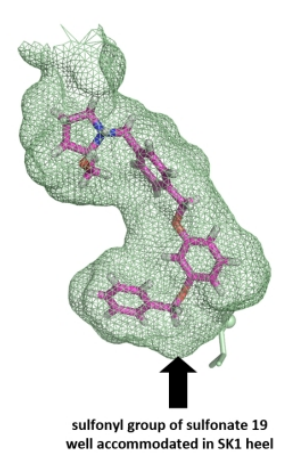

(D)

overlay (B) and (C)

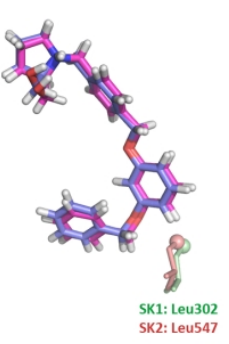

Figure 6. The J-channel heel is a key determinant of isoform discrimination by SK inhibitors. Panel (A): LBL2 and LBL-3 are shown from the co-crystal structure (4V24) of PF-543 (orange stick) with SK1 (green ribbon); the corresponding elements from our SK2 homology model (red ribbon) are overlaid, illustrating inward movement in LBL-3 leading to heel compression in SK2 by Leu547. Panel (B): Potent unselective inhibitor 49 (blue stick) is shown modelled into the SK2 J-channel (red mesh); the J-channel heel surface is driven significantly inwards relative to SK1 so that the presence of a sulfonyl group in the ligand (49 --> 19, 56 -fold activity loss) is poorly tolerated by SK2. Panel (C): Inhibitor 49 (magenta stick) is again shown, here modelled into the SK1 J-channel (green mesh); the SK1 J-channel heel surface exhibits less compression and accommodates a sterically more demanding sulfonyl containing linker more readily (49--> 19, no activity loss; 23 --> 18, 5-fold activity loss). Panel (D): overlay of (B) and (C) minus the J-channel surface. 


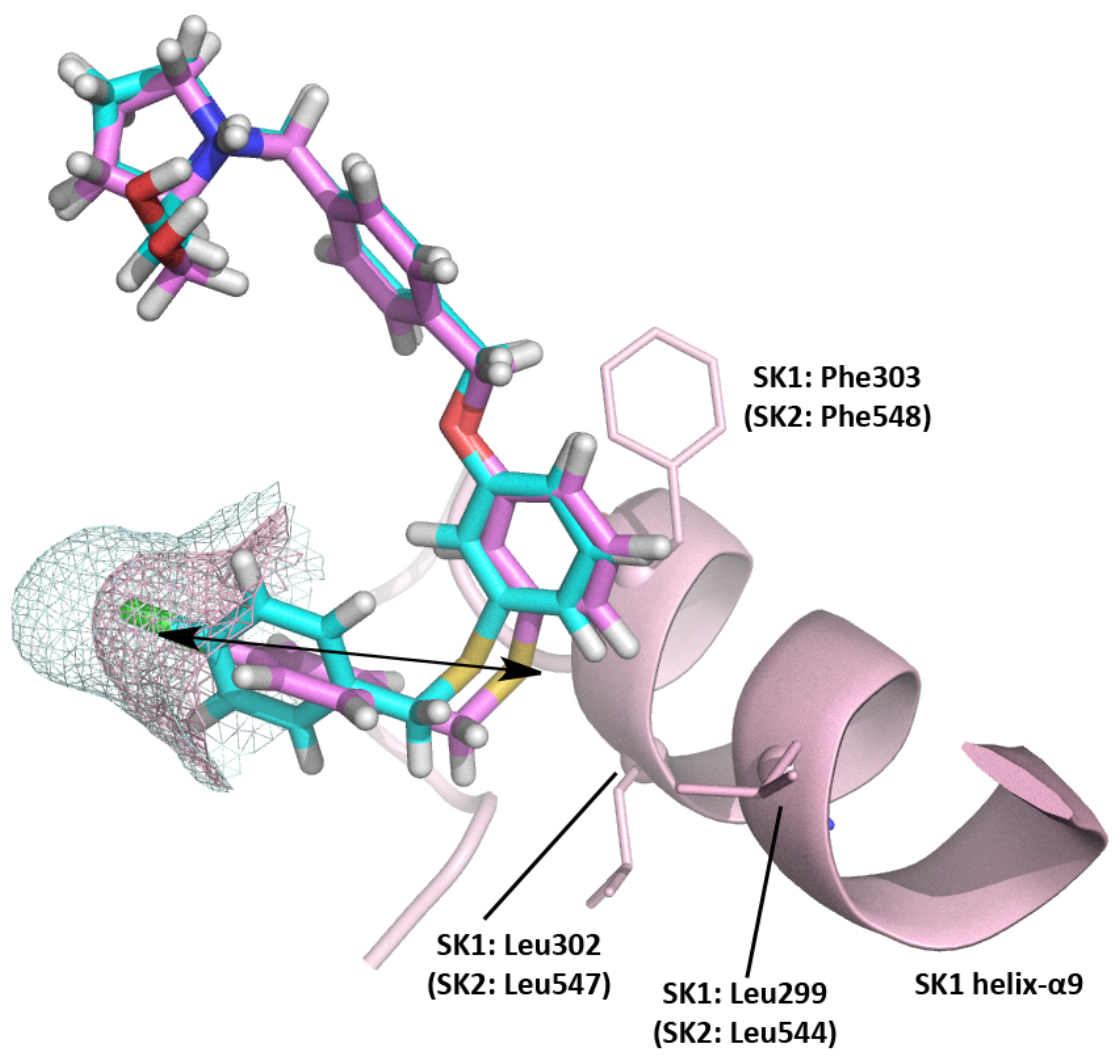

Figure 7. The J-channel toe is a second key determinant for isoform discrimination by SK inhibitors. A comparison of modelled binding modes for the SK2-selective inhibitor (60) is shown here, with the SK2docked inhibitor (cyan stick) superimposed onto the SK1-docked inhibitor (magenta stick). With reduced plasticity in the SK1 J-channel toe (pink mesh), the sulfur atom of 60 is predicted to be tightly wedged against the backbone of helix-a9 (pink ribbon). This generates an unfavourable compression axis (black arrow, corresponding to 'Axis-2' of Figure 3) that preferentially penalizes binding to SK1. In SK2 the greater plasticity of the J-channel toe (cyan mesh) is predicted to allow accommodation of 60 with less compression.

$84 \times 69 \mathrm{~mm}(299 \times 299 \mathrm{DPI})$ 

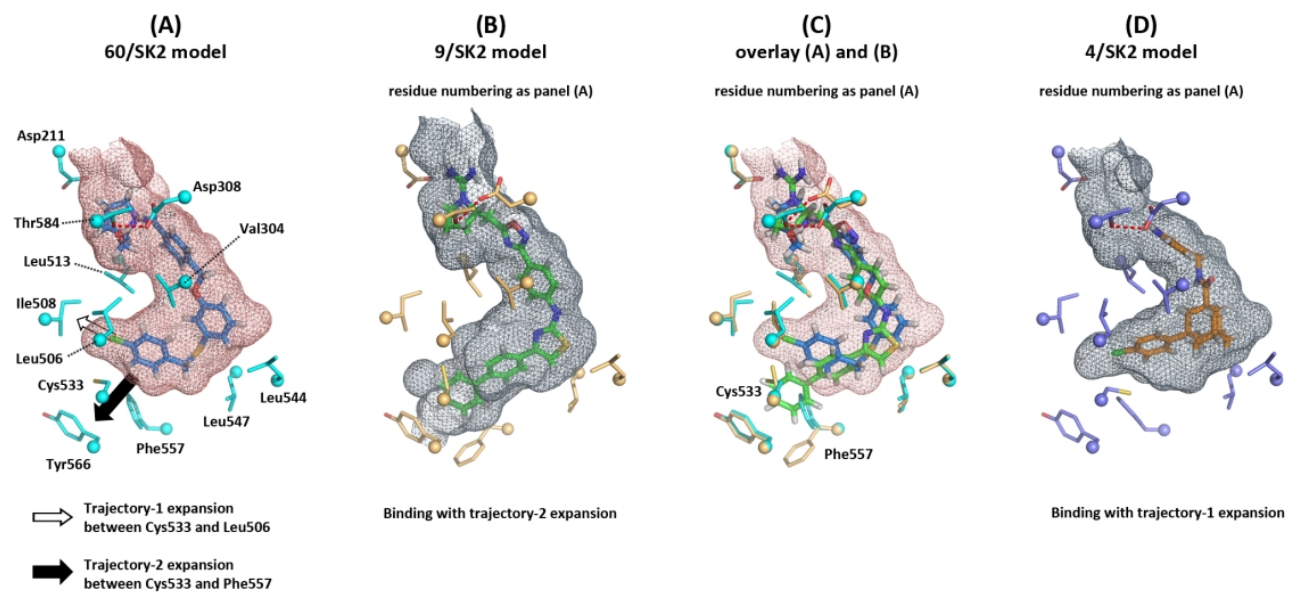

Figure 8. Plasticity in the J-channel toe of SK2 may be exploited to develop SK2-selective inhibitors. Panel (A): Compound 60 (blue stick) docked into the SK2 model (red mesh), highlighting key contact residues (cyan stick) and two predicted trajectories for possible toe expansion (arrows). Small groups may be accommodated between Cys533 and Leu506 (Trajectory-1, hollow ar-row). This is the predicted expansion for binding of 55/60, where the fit of the $\mathrm{Cl}$ atom is likely made possible largely by rotation in Leu506. Larger groups may be accommodated between Cys533 and Phe557 (Trajectory-2, filled arrow) upon rotation of these side chains. Panel (B): VT-20dd (9, green stick) docked into the SK2 model (grey mesh), highlighting key contact residues (orange stick). Here the ligand is predicted to exploit the second toe expansion trajectory. Panel (C): Overlay of (A) and (B) showing the SK2 J-channel surface for docked 60 (red mesh) and illustrating the two key residue rotations in Cys533 and Phe557 required for Trajectory-2 expansion (cyan stick --> orange stick positions). Panel (D): ABC294640 (4, orange stick) docked into SK2 (grey mesh). In this model, the Trajectory-1 expansion is made possible chiefly by rotation of Cys533 rather than Leu506, but the space generated by the expansion is underused by the $\mathrm{Cl}$ atom. 


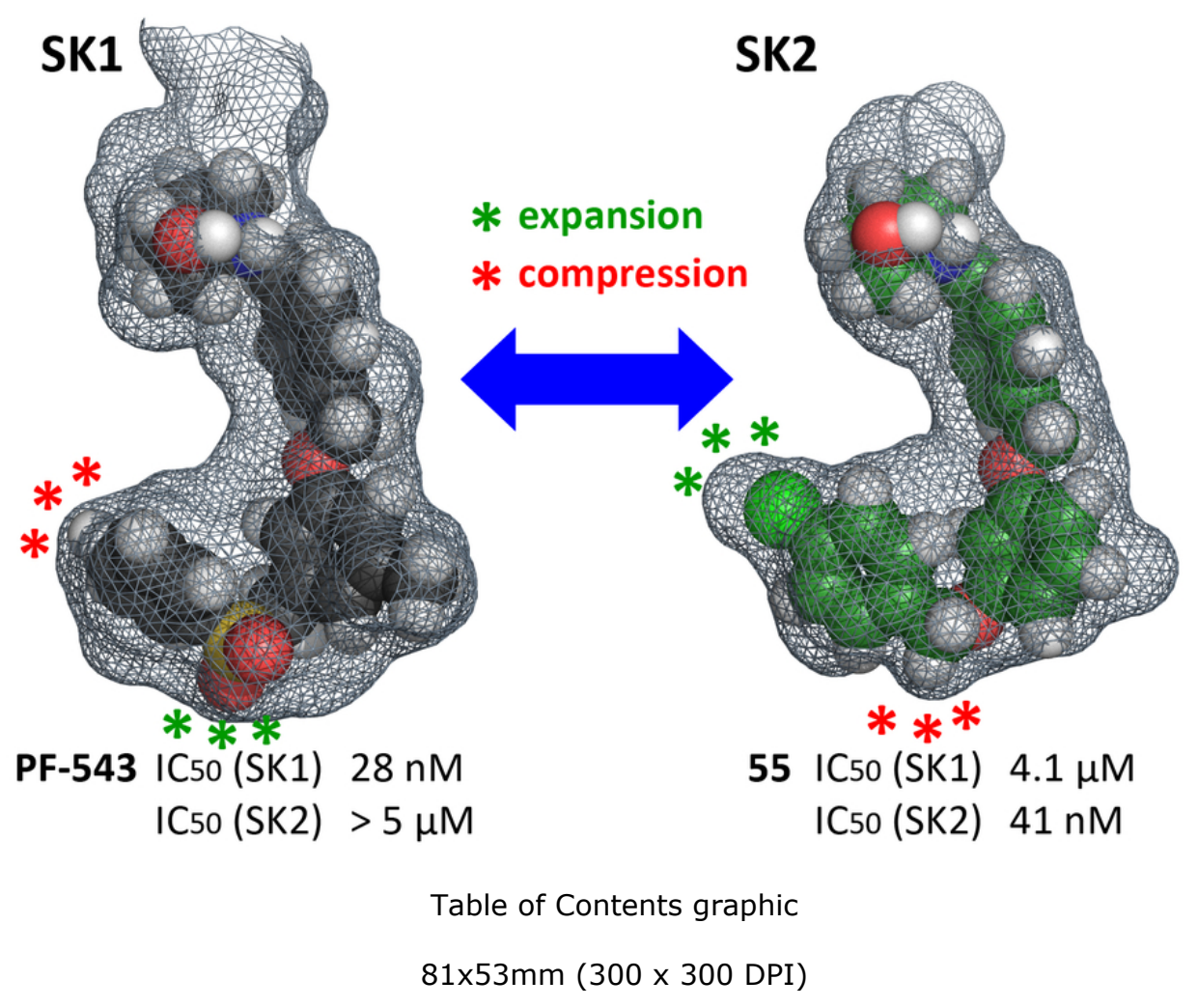

ACS Paragon Plus Environment 